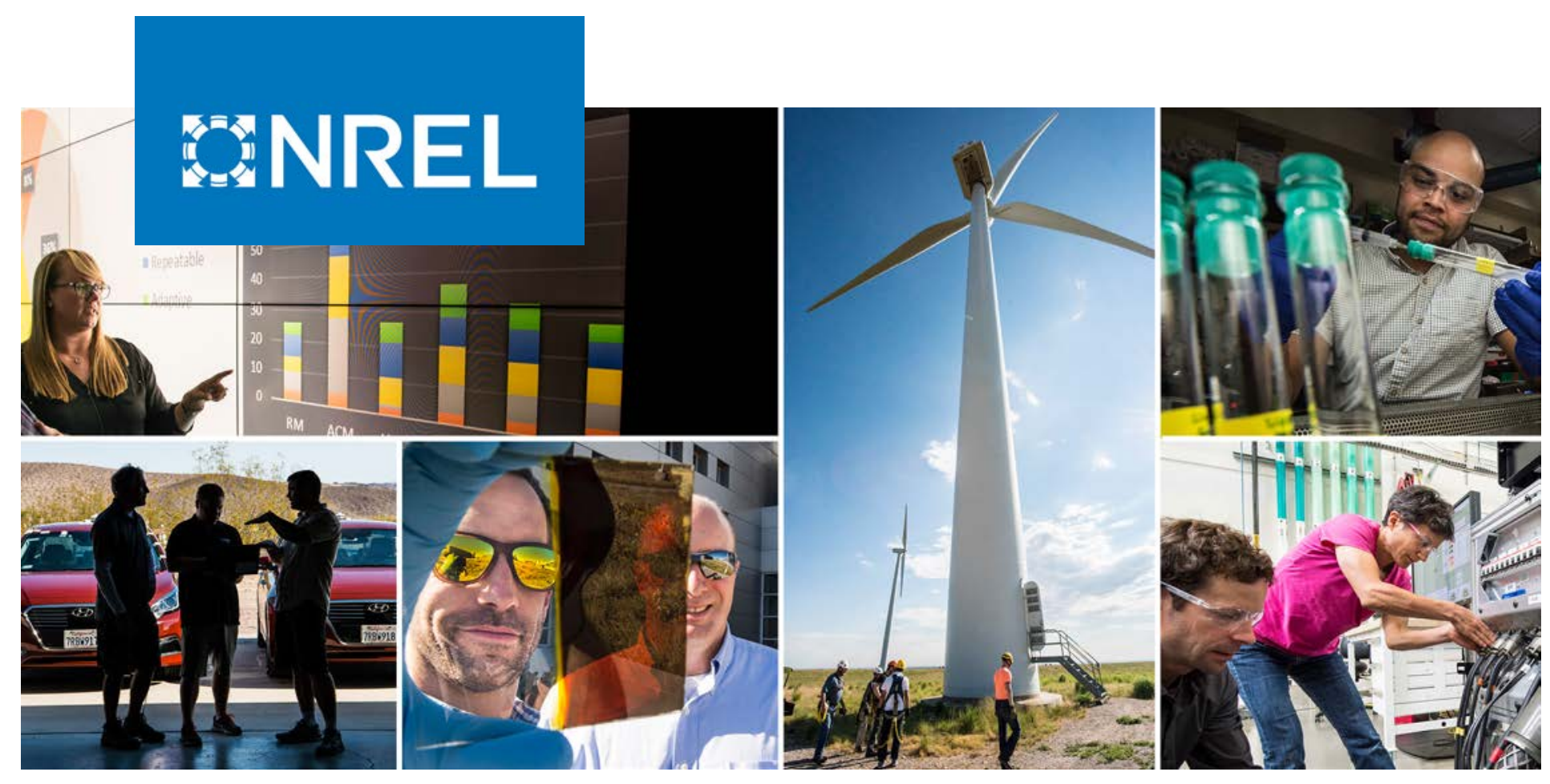

\title{
Status and Trends in the U.S. Voluntary Green Power Market (2017 Data)
}

Eric O'Shaughnessy, Jenny Heeter, and Jenny Sauer

National Renewable Energy Laboratory

NREL is a national laboratory of the U.S. Department of Energy

Office of Energy Efficiency \& Renewable Energy

Operated by the Alliance for Sustainable Energy, LLC

This report is available at no cost from the National Renewable Energy Laboratory (NREL) at www.nrel.gov/publications.

\section{Technical Report}

NREL/TP-6A20-72204

October 2018 


\title{
GNREL
}

\section{Status and Trends in the U.S. Voluntary Green Power Market (2017 Data)}

\author{
Eric O'Shaughnessy, Jenny Heeter, and Jenny Sauer
}

National Renewable Energy Laboratory

Suggested Citation

O'Shaughnessy, Eric, Jenny Heeter, and Jenny Sauer. 2018. Status and Trends in the U.S. Voluntary Green Power Market: 2017 Data. Golden, CO: National Renewable Energy Laboratory. NREL/TP-6A20-72204. https://www.nrel.gov/docs/fy19osti/72204.pdf.

NREL is a national laboratory of the U.S. Department of Energy Office of Energy Efficiency \& Renewable Energy Operated by the Alliance for Sustainable Energy, LLC

This report is available at no cost from the National Renewable Energy Laboratory (NREL) at www.nrel.gov/publications.

Contract No. DE-AC36-08GO28308
Technical Report

NREL/TP-6A20-72204

October 2018

National Renewable Energy Laboratory 15013 Denver West Parkway Golden, CO 80401

303-275-3000 • www.nrel.gov 


\section{NOTICE}

This work was authored by the National Renewable Energy Laboratory, operated by Alliance for Sustainable Energy, LLC, for the U.S. Department of Energy (DOE) under Contract No. DE-AC36-08G028308. Funding provided by U.S. Department of Energy Office of Energy Efficiency and Renewable Energy Strategic Programs. The views expressed herein do not necessarily represent the views of the DOE or the U.S. Government.

This report is available at no cost from the National Renewable Energy Laboratory (NREL) at www.nrel.gov/publications.

U.S. Department of Energy (DOE) reports produced after 1991 and a growing number of pre-1991 documents are available free via www.OSTI.gov.

Cover Photos by Dennis Schroeder: (clockwise, left to right) NREL 51934, NREL 45897, NREL 42160, NREL 45891, NREL 48097, NREL 46526.

NREL prints on paper that contains recycled content. 


\section{Acknowledgments}

This work was funded by the U.S. Department of Energy's Office of Energy Efficiency and Renewable Energy. The authors thank the Strategic Programs Office and the Solar Energy Technologies Office for its support of this work. For their thoughtful review of the document, the authors thank Celina Bonugli (World Resources Institute), Stephen Capanna (DOE), Ilya Chernyakhovskiy (NREL), Ed Holt (Ed Holt \& Associates), Richard Graves (CleanChoice Energy), Todd Jones (Center for Resource Solutions), Tom Matzzie (CleanChoice Energy), Kara Podkaminer (DOE), Ammar Qusaibaty (DOE), David Rench McCauley (DOE), Jennifer Spinosi (CleanChoice Energy), and Dawn Weisz (MCE), as well as Mike Meshek of NREL for editorial support. Finally, the authors thank the many green power marketers and utility contacts who provided the information summarized in this report. 


\section{Executive Summary}

Most renewable energy procurement in the United States falls into one of two categories. Compliance-based purchasing refers to renewable energy procurement by load-serving entities to comply with state renewable energy mandates. Voluntary purchasing or voluntary "green power," for the purposes of this report, refers to voluntary renewable energy procurement by retail electricity customers in excess of state renewable energy mandates. In this report, we present data and key trends for voluntary green power markets, except for a small portion of voluntary purchasing where no data are available.

In 2017, about 5.5 million retail electricity customers procured about 112 million megawatthours (MWh) of green power, representing about $26 \%$ of all U.S. renewable energy sales (excluding large hydropower) (Figure ES-1) or about $3 \%$ of all U.S. retail electricity sales. For comparison, compliance-based procurement accounted for about $57 \%$ of renewable energy procurement.

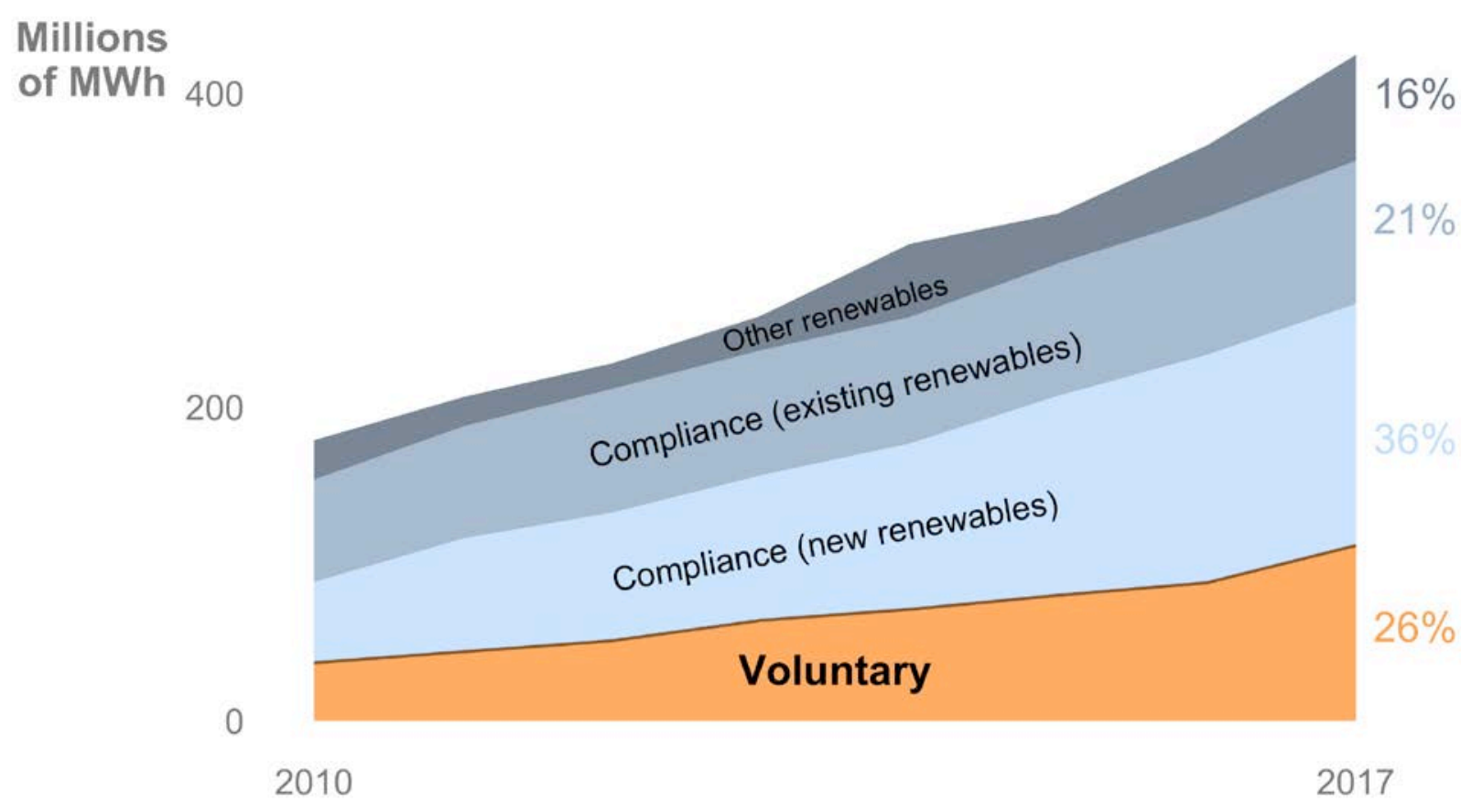

Figure ES-1. Voluntary green power sales (MWh), 2010-2017

This report summarizes the status and trends of sales of seven ways that customers can obtain green power. These options, described here as green power products, are utility green pricing programs, utility renewable contracts, unbundled renewable energy certificates, competitive suppliers, community choice aggregations, power purchase agreements, and community solar. Key trends include:

- Utility green pricing programs, which have generally relied on wind, are increasing their procurement of solar energy, especially among the 10 largest programs. 
- Unbundled renewable energy certificates - which are primarily purchased by large nonresidential customers - continue to account for the majority of voluntary green power sales (about 46\%) (Figure ES-2).

- Green power sales through power purchase agreements exhibited the strongest year-overyear growth in absolute terms, increasing by about 12.7 million MWh from 2016 to 2017.

- Community choice aggregations — which primarily serve residential and small commercial customers - account for about half of green power customers.

- Green power sales through community solar programs exhibited the strongest year-over-year growth in relative terms, increasing eightfold from 2016 to 2017 mostly due to the implementation of new utility-administered community solar green power programs.

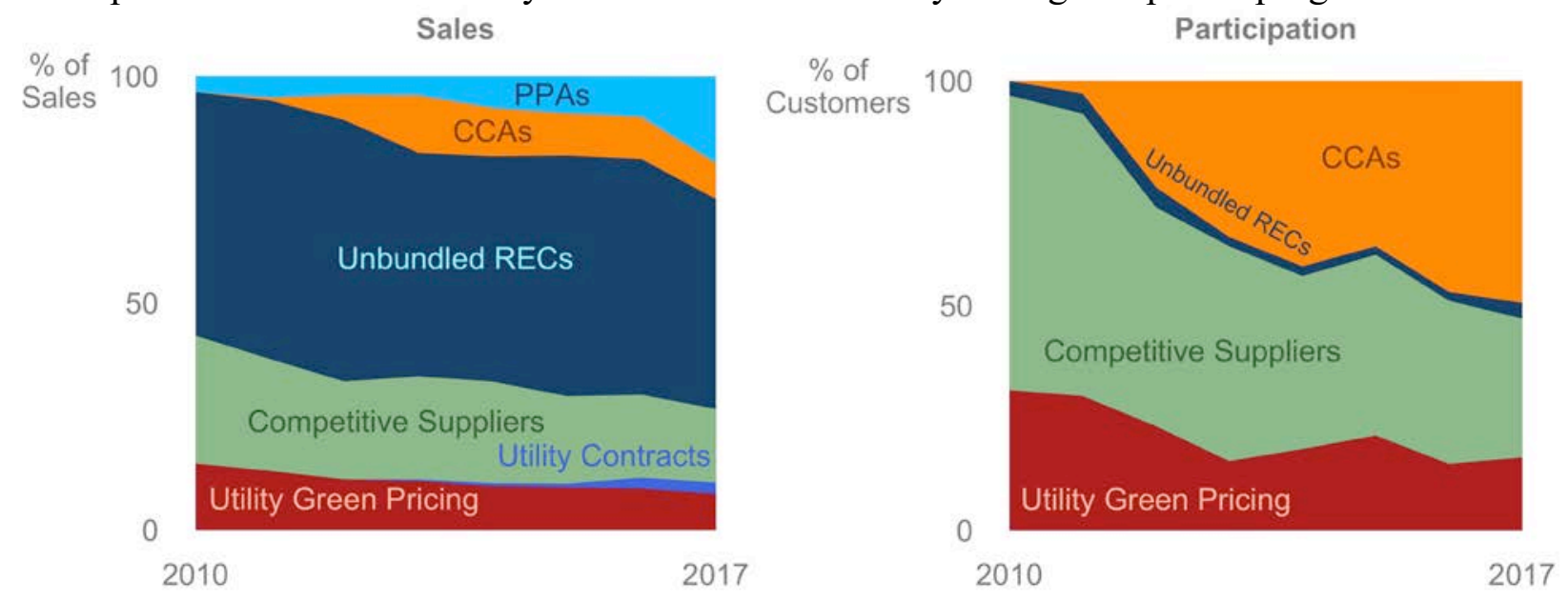

Figure ES-2. Voluntary green power market shares of different products in terms of sales (left) and customers (right), 2010-2017

PPA = power purchase agreement CCA = community choice aggregation; $\mathrm{REC}=$ renewable energy certificates

The ongoing growth of the U.S. voluntary green power market is driven primarily by increased sales of existing products, especially unbundled renewable energy certificates - which grew by 32 million MWh from 2010 to 2017, but also the expansion of new products like community choice aggregations and power purchase agreements - which together grew by 29 million MWh from 2010 to 2017. As these new products expand, there is the potential for customer confusion and for customers to misunderstand the impact of their purchase. Measures to increase product transparency, particularly for new products like community choice aggregations and community solar, could help customers better understand the impact of their purchasing decisions. 


\section{Table of Contents}

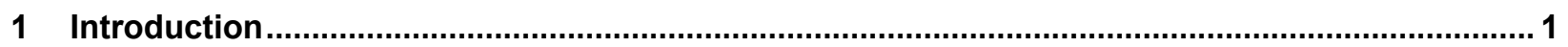

2 Summary of Voluntary Green Power Participation and Sales ................................................... 4

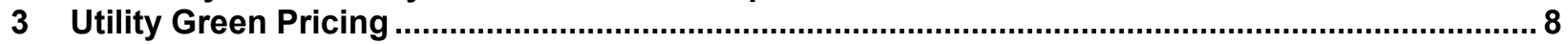

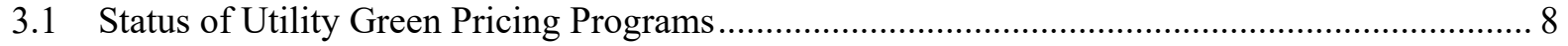

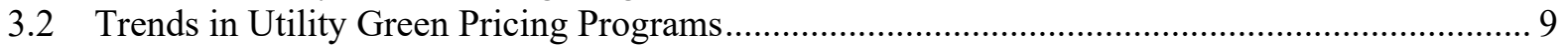

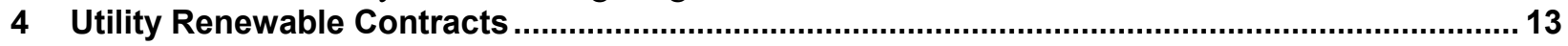

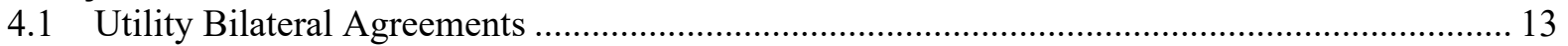

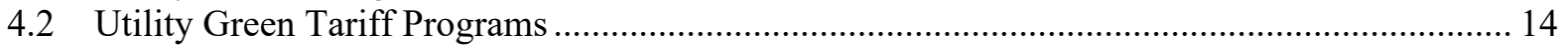

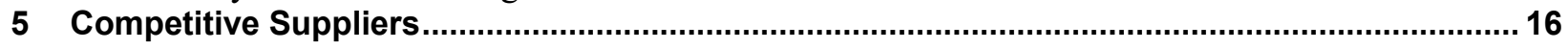

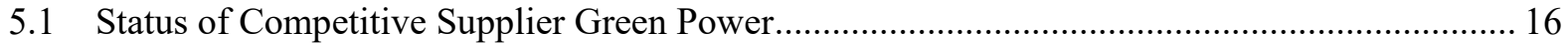

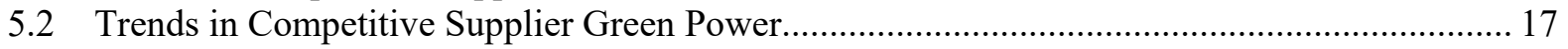

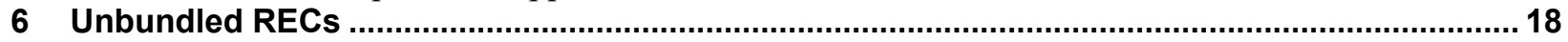

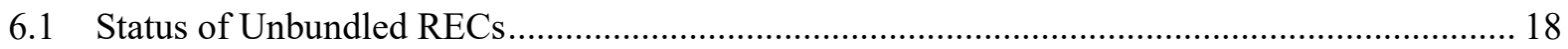

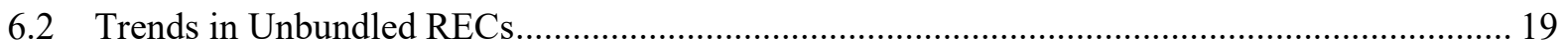

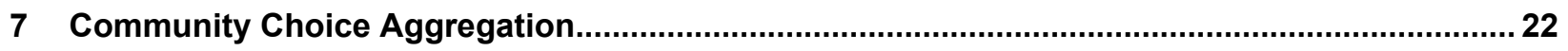

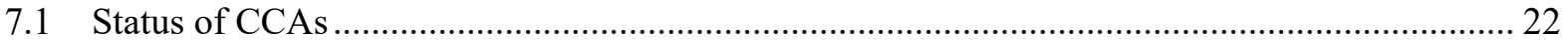

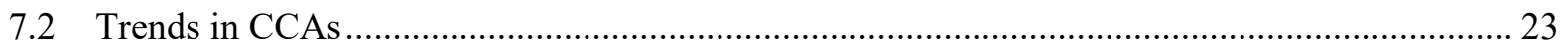

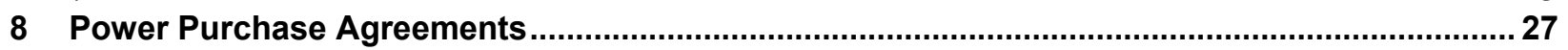

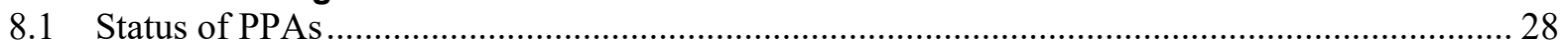

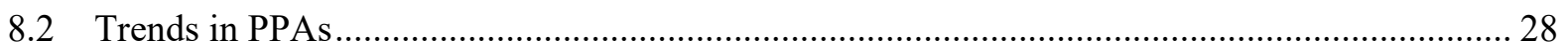

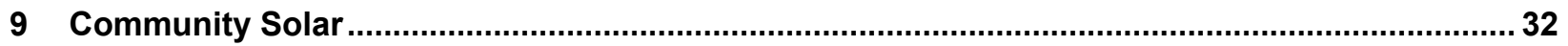

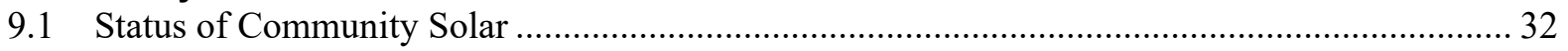

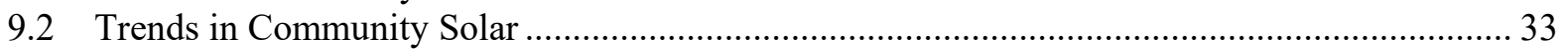

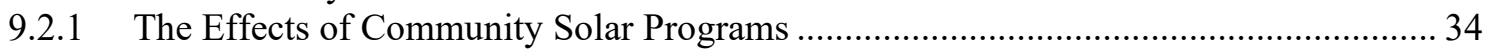

9.2.2 Community Solar Green Power Products .............................................................. 36

10 Expanding Electricity Product Choice: Opportunities and Challenges for Green Power Markets

10.1 Above-RPS Utility Basic Service as a Green Power Product ................................................ 41

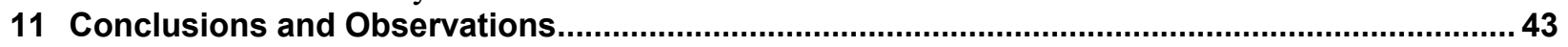

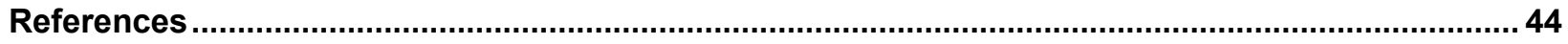

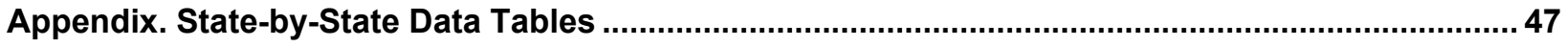




\section{List of Figures}

Figure ES-1. Voluntary green power sales (MWh), 2010-2017 ............................................................

Figure ES-2. Voluntary green power market shares of different products in terms of sales (left) and customers (right), 2010-2017 ............................................................................................. vi

Figure 1. Shares of green power sales (left) and customers (right) over time by product .......................... 4

Figure 2. Green power sales by mechanism, 2010-2017 ................................................................. 5

Figure 3. Green power participation by mechanism (2010-2017) ................................................. 6

Figure 4. Renewable energy sales in voluntary, compliance, and other markets, 2010-2017................. 7

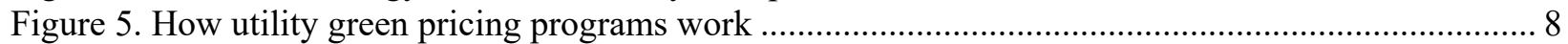

Figure 6. Utility green pricing program sales and participation, 2010-2017 ..................................... 8

Figure 7. Residential and nonresidential utility green pricing sales in top 10 and other programs ............. 9

Figure 8. Percentage of solar in green power portfolios of top 10 and other utility green pricing programs

Figure 9. Average green pricing premium for programs offering different percentages of solar.............. 11

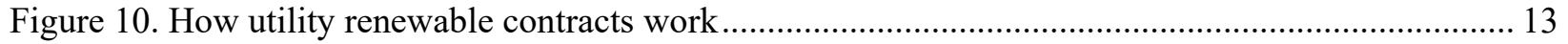

Figure 11. Annual green power sales through utility bilateral contracts ........................................... 14

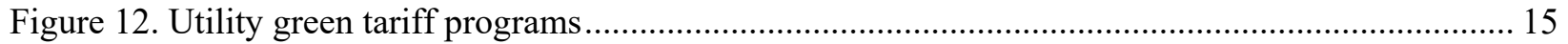

Figure 13. Annual green power sales through utility green tariff programs ......................................... 15

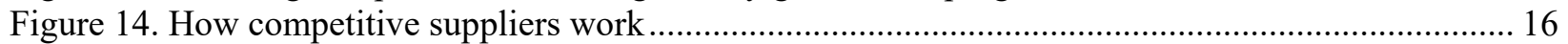

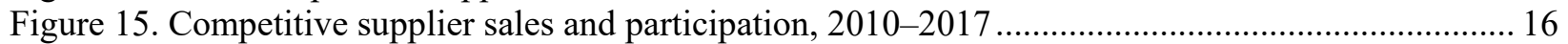

Figure 16. Competitive supplier green power sales by top eight suppliers and other suppliers ................. 17

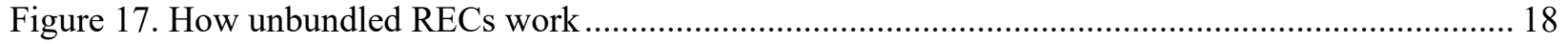

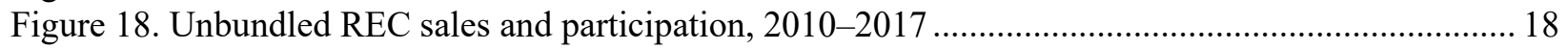

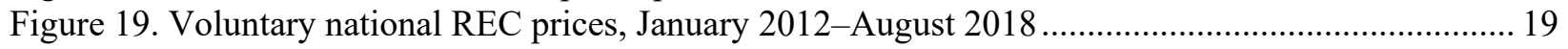

Figure 20. Prices of RECs used for compliance (excluding SRECs), January 2012-August 2018 ......... 20

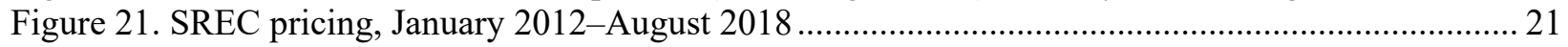

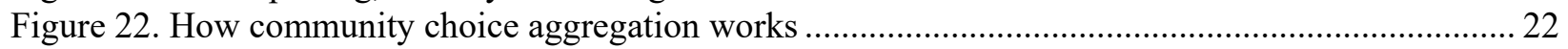

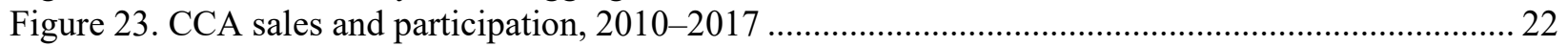

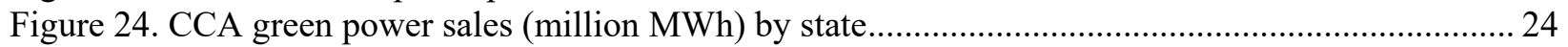

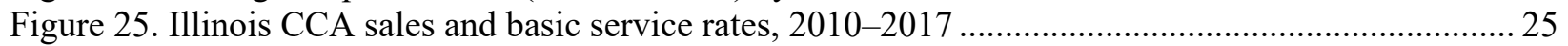

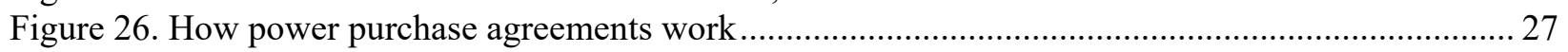

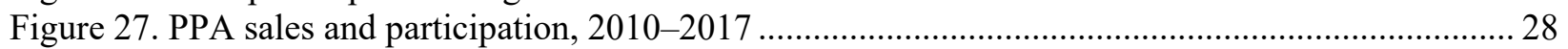

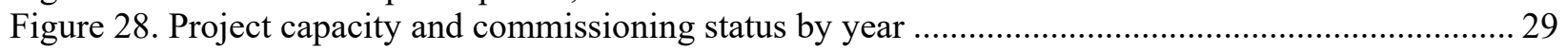

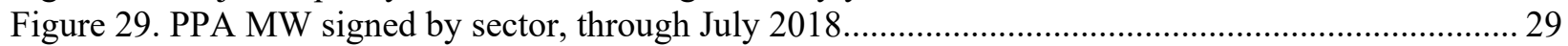

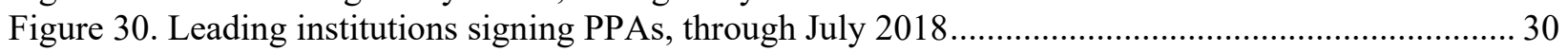

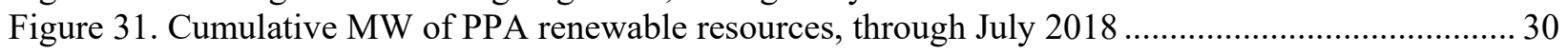

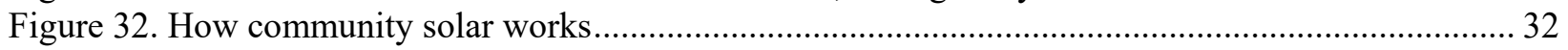

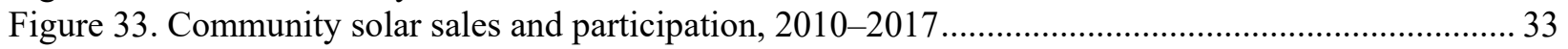

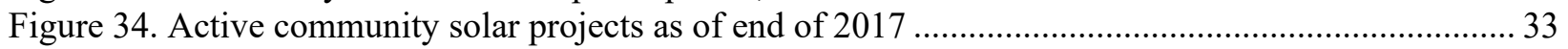

Figure 35. Current and projected community solar capacity in six leading states ................................... 34

Figure 36. Customer product switching pathways that increase green power demand ............................ 39

Figure 37. Customer product switching pathways that decrease green power demand............................ 39

Figure 38. Green power share of total sales by electricity product........................................................... 40 


\section{List of Tables}

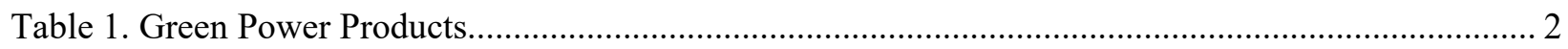

Table 2. Methodologies, Resources, and Data Limitations .............................................................. 3

Table 3. Voluntary Green Power Participation and Sales in 2017 f.................................................... 4

Table 4. Estimated Green Power Sales (millions of MWh), 2013-2017 …........................................ 5

Table 5. Estimated Green Power Participation ( $\times 1,000$ customers), 2012-2017 …............................... 6

Table 6. Contract Length by Type of Utility Green Power Procurement (MWh), 2017 ......................... 12

Table 7. CCA Green Power Sales and Participation by State in 2017 ....................................................23

Table 8. Potential Community Solar Green Power Models .................................................................... 36

Table A-1. Green Power Customers by State ..................................................................................... 47

Table A-2. Estimated Green Power Production (MWh) by State of Origin ${ }^{\mathrm{a}}$...........................................50 


\section{Introduction}

Most renewable energy procurement in the United States falls into one of two categories. Compliance-based purchasing refers to renewable energy procurement by load-serving entities to comply with state renewable energy mandates known as renewable portfolio standards (RPS). Voluntary green power, for the purposes of this report, refers to voluntary renewable energy procurement by retail electricity customers in excess of RPS. ${ }^{1}$ Both types of procurement are verified through renewable energy certificates (RECs), accounting mechanisms that represent the clean energy attributes of one megawatt-hour (MWh) of renewable electricity. When a REC is "retired" on behalf of a specific user, that user has the sole right to claim the use of the renewable energy represented by that REC, thus preventing the double counting of renewable energy use claims. ${ }^{2}$ For more information on RECs and their role in voluntary green power markets, see NREL (2015) and EPA (2018). The report summarizes data on the various ways in which retail electricity customers - including residential, commercial \& industrial (C\&I), and institutional (e.g., government) customers - purchase voluntary green power. For similar data from compliance-based markets, see Barbose (2017).

Table 1 on the following page summarizes the seven ways that customers can buy green power, which we refer to as green power products. For each green power product, RECs are retired on behalf of retail electricity customers to allow those customers to make valid claims to renewable energy use. The inclusion of RECs in all seven green power products ensures that the associated renewable energy use cannot be double counted and claimed by a utility for RPS compliance. In other words, all sales through the green power products are above and beyond sales that would have occurred anyway due to state RPS. The availability of the seven green power products varies geographically based on state electricity market structure, laws, and regulations.

For the purposes of this report, the term green power refers exclusively to renewable energy procurement that exceeds RPS obligations. For example, competitive suppliers and community choice aggregations (CCAs) are subject to RPS compliance in states with RPS, and therefore a fraction of their sales is used to meet their compliance obligations. All voluntary green power sales estimates (MWh) reported here for competitive suppliers and CCAs exclude the portion of renewable energy sales used toward RPS compliance.

This report does not include green power use where no explicit REC transaction occurs and therefore no usage data are available. This lack of data/absence of REC transaction occurs when customers own on-site systems and "retain" the RECs, so that RECs are never sold or recorded in one the seven green power products defined in Table 1. Data from the U.S. EPA's Green Power Partnership suggest that on-site green power consumption by nonresidential customers may amount to about $4 \%$ of the green power market summarized in the report, or about four million MWh annually. Additional on-site green power, not accounted for in this report, is

\footnotetext{
${ }^{1}$ This definition is consistent with the definition used by the U.S. Environmental Protection Agency. See EPA (2018) for more information about voluntary green power.

${ }^{2}$ RECs are formally recognized as a valid basis for making renewable energy use claims by the Federal Trade Commission, the U.S. Environmental Protection Agency, the U.S. Federal Energy Regulatory Commission, the U.S. Federal Energy Management Program, the American Bar Association, and at least 35 U.S. states and territories. See Jones, Quarrier, and Kelty (2015) for a more complete discussion of the legal basis of RECs.
} 
occurring through residential installations and organizations that are not part of the Green Power Partnership. Further, this report does not discuss potential costs of integrating voluntary green power resources into the grid or the technical impacts of voluntary green power markets on electric grids.

Table 1. Green Power Products

\begin{tabular}{|c|c|c|}
\hline Product & Description & Customer Classes \\
\hline Utility green pricing & $\begin{array}{l}\text { Utility customers procure green power on a month-to- } \\
\text { month basis through an added fee on their utility bill }\end{array}$ & $\begin{array}{l}\text { Residential, small } \\
\text { commercial }\end{array}$ \\
\hline $\begin{array}{l}\text { Utility renewable } \\
\text { contracts }\end{array}$ & $\begin{array}{l}\text { Utility customers procure green power from their utility } \\
\text { through a special tariff or bilateral contract, typically } \\
\text { on a long-term basis sourced from a new renewable } \\
\text { energy generator }\end{array}$ & Large C\&I \\
\hline Unbundled RECs & $\begin{array}{l}\text { Retail customers buy RECs separated or "unbundled" } \\
\text { from the underlying electricity. This category refers } \\
\text { only to sales of unbundled RECs directly to retail } \\
\text { customers, it excludes sales of unbundled RECs } \\
\text { through other green power products (e.g., utility green } \\
\text { pricing) to avoid double counting. }\end{array}$ & $\begin{array}{l}\text { All, mostly C\&I and } \\
\text { institutional }\end{array}$ \\
\hline Competitive suppliers & $\begin{array}{l}\text { Customers in competitive electricity markets may } \\
\text { select a green power option from an alternative retail } \\
\text { electricity supplier }\end{array}$ & All \\
\hline $\begin{array}{l}\text { Community choice } \\
\text { aggregations (CCA) }\end{array}$ & $\begin{array}{l}\text { Communities aggregate their loads to collectively } \\
\text { procure green power as a bulk purchaser through an } \\
\text { alternative electricity supplier }\end{array}$ & $\begin{array}{l}\text { All, mostly } \\
\text { residential and small } \\
\text { commercial }\end{array}$ \\
\hline $\begin{array}{l}\text { Power purchase } \\
\text { agreements (PPA) }\end{array}$ & $\begin{array}{l}\text { Customers procure green power through a long-term } \\
\text { contract with an off-site renewable energy project }\end{array}$ & C\&I, institutional* \\
\hline Community solar & $\begin{array}{l}\text { Customers buy a subscription in a shared solar } \\
\text { project and accrue green power in proportion to their } \\
\text { subscription }\end{array}$ & $\begin{array}{l}\text { All, mostly } \\
\text { residential and small } \\
\text { commercial }\end{array}$ \\
\hline
\end{tabular}

${ }^{*}$ Residential customers also sign PPAs, however RECs are typically owned by the project owner rather than the end-use customer. Residential PPAs are excluded from this report.

\section{Data Sources and Limitations}

Green power market data are based on figures provided to the National Renewable Energy Laboratory (NREL) by utilities and independent renewable energy marketers and publicly available data (Table 2). The data on voluntary market trends presented in this report build on data presented in Status and Trends in the U.S. Voluntary Green Power Market (2016 Data) (O’Shaughnessy et al. 2017). 
Table 2. Methodologies, Resources, and Data Limitations

\begin{tabular}{|c|c|}
\hline Product & Methodology, Resources, and Limitations \\
\hline Utility green pricing & $\begin{array}{l}\text { National estimate extrapolated from data collected from } 46 \text { utility } \\
\text { programs. NREL estimates that the data sample represents over } \\
80 \% \text { of utility green pricing sales }\end{array}$ \\
\hline $\begin{array}{l}\text { Utility renewable } \\
\text { contracts }\end{array}$ & $\begin{array}{l}\text { Estimates based on data from WRI (2018); Heeter, Cook, and } \\
\text { Bird (2017); and data collected by NREL }\end{array}$ \\
\hline Unbundled RECs & $\begin{array}{l}\text { National estimate extrapolated from data provided by the Green-e } \\
\text { national certification program (Leschke 2018) and NREL survey } \\
\text { data. }\end{array}$ \\
\hline Competitive suppliers & $\begin{array}{l}\text { Estimates based on survey data, data from EIA Form-861 (EIA } \\
\text { 2018a), and competitive supplier websites }\end{array}$ \\
\hline $\begin{array}{l}\text { Community choice } \\
\text { aggregations }\end{array}$ & $\begin{array}{l}\text { Estimates for Massachusetts and Ohio based on data collected from } \\
\text { CCAs; estimates for California based on Trumbull (2018); estimates } \\
\text { for Illinois based on information from ICC (2018a; 2018b) and } \\
\text { Homefield Energy (2018); estimates for New York based on } \\
\text { Westchester Power (2018). }\end{array}$ \\
\hline $\begin{array}{l}\text { Power purchase } \\
\text { agreements }\end{array}$ & $\begin{array}{l}\text { Based on data obtained from BNEF (2018) and S\&P Global Market } \\
\text { Intelligence (2018). }\end{array}$ \\
\hline Community solar & $\begin{array}{l}\text { Based on data on operational community solar projects compiled } \\
\text { from various sources (O'Shaughnessy et al. 2018), state-level solar } \\
\text { capacity factors, and assumed average subscription sizes per } \\
\text { customer; REC treatment is unknown for most projects. Community } \\
\text { solar sales and participation figures are therefore excluded from } \\
\text { green power market totals, except for sales and participation from } \\
\text { programs administered by MCE, Pacific Gas \& Electric, Rocky } \\
\text { Mountain Power, and Sacramento Municipal Utility District (where by } \\
\text { design customers retain RECs). }\end{array}$ \\
\hline
\end{tabular}

\section{Structure of this Report}

Section 2 provides an overall summary of the status of the green power market with national totals of sales (MWh) and participation (number of customers). We provide state-level estimates of green power sales and participation in the Appendix. Sections 3-9 summarize the status and trends for each of the green power procurement mechanisms. Section 10 analyzes how the expansion of new retail electricity products may affect voluntary green power markets. Section 11 concludes the report. 


\section{Summary of Voluntary Green Power Participation and Sales}

About 5.5 million U.S. electricity customers purchased about 112 million MWh of green power in 2017 (Table 3), which represents about a 27\% increase in green power sales from 2016 to $2017 .^{3}$

Table 3. Voluntary Green Power Participation and Sales in 2017

\begin{tabular}{lrr}
\hline Green Power Option & Sales (MWh) & Participants \\
\hline Utility green pricing & $8,850,000$ & 885,000 \\
Utility renewable contracts & $2,788,000$ & 15 \\
Competitive suppliers & $18,133,000$ & $1,691,000$ \\
Unbundled RECs & $51,744,000$ & 192,000 \\
CCAs & $8,882,000$ & $2,726,000$ \\
PPAs & $21,271,000$ & 273 \\
Community solar & 80,400 & 4,700 \\
\hline Total & $111,748,000$ & $5,499,000$ \\
\hline
\end{tabular}

PPAs, unbundled RECs, and utility renewable contracts tend to be purchased in large quantities by larger nonresidential electricity customers. As a result, these products account for about $68 \%$ of green power sales but only account for about $4 \%$ of customers (Figure 1). In contrast, CCAs, competitive suppliers, and utility green pricing programs primarily serve small electricity buyers such as residential and small commercial customers. These products account for about $96 \%$ of green power customers but only about $32 \%$ of green power sales.

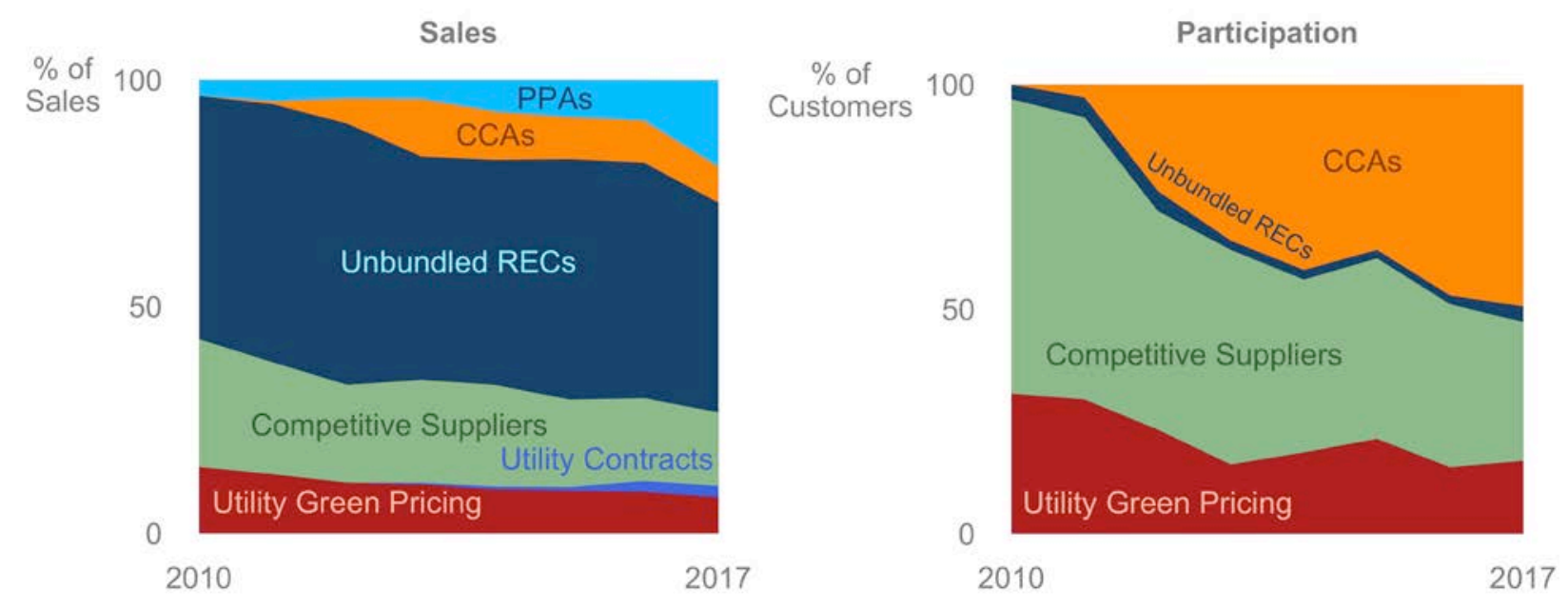

Figure 1. Shares of green power sales (left) and customers (right) over time by product

Community solar, PPAs, and utility contracts collectively account for less than $1 \%$ of customers.

\footnotetext{
${ }^{3}$ All of the data in this section and data behind certain figures in this report are available in a spreadsheet format at https://data.nrel.gov/submissions/98 (“U.S. Voluntary Green Power Market Data 2017,” NREL).
} 
For the first time, U.S. voluntary green power sales broke 100 million MWh in 2017, reaching about 112 million MWh (Table 4). Unbundled RECs continue to account for nearly half (46\%) of the green power market in terms of sales. Green power sales through PPAs more than doubled from 2016 to 2017, accounting for more than half of the increase in market wide green power sales (Figure 2).

Table 4. Estimated Green Power Sales (millions of MWh), 2012-2017a

\begin{tabular}{lrrrccc}
\hline Green Power Option & $\mathbf{2 0 1 2}$ & $\mathbf{2 0 1 3}$ & $\mathbf{2 0 1 4}$ & $\mathbf{2 0 1 5}$ & $\mathbf{2 0 1 6}$ & $\mathbf{2 0 1 7}$ \\
\hline Utility green pricing & 6.0 & 6.9 & 7.0 & 7.5 & 8.0 & 8.9 \\
Utility contracts & 0 & 0.2 & 0.5 & 0.7 & 2.1 & 2.8 \\
Competitive suppliers & 11.6 & 14.5 & 16.2 & 15.4 & 16.0 & 18.1 \\
Unbundled RECs & 31.0 & 31.4 & 36.0 & 42.5 & 45.5 & 51.7 \\
CCAs & 3.0 & 8.1 & 7.7 & 7.4 & 8.1 & 8.9 \\
PPAs & 2.2 & 2.7 & 5.1 & 6.6 & 7.9 & 21.3 \\
Community solar & 0 & 0 & 0 & 0 & 0.01 & 0.08 \\
\hline Total & $\mathbf{5 4}$ & $\mathbf{6 4}$ & $\mathbf{7 3}$ & $\mathbf{8 0}$ & $\mathbf{8 8}$ & $\mathbf{1 1 2}$ \\
\hline
\end{tabular}

a We continuously update historical results based on improved data and methods; some historical results differ from results provided in previous versions of this report.
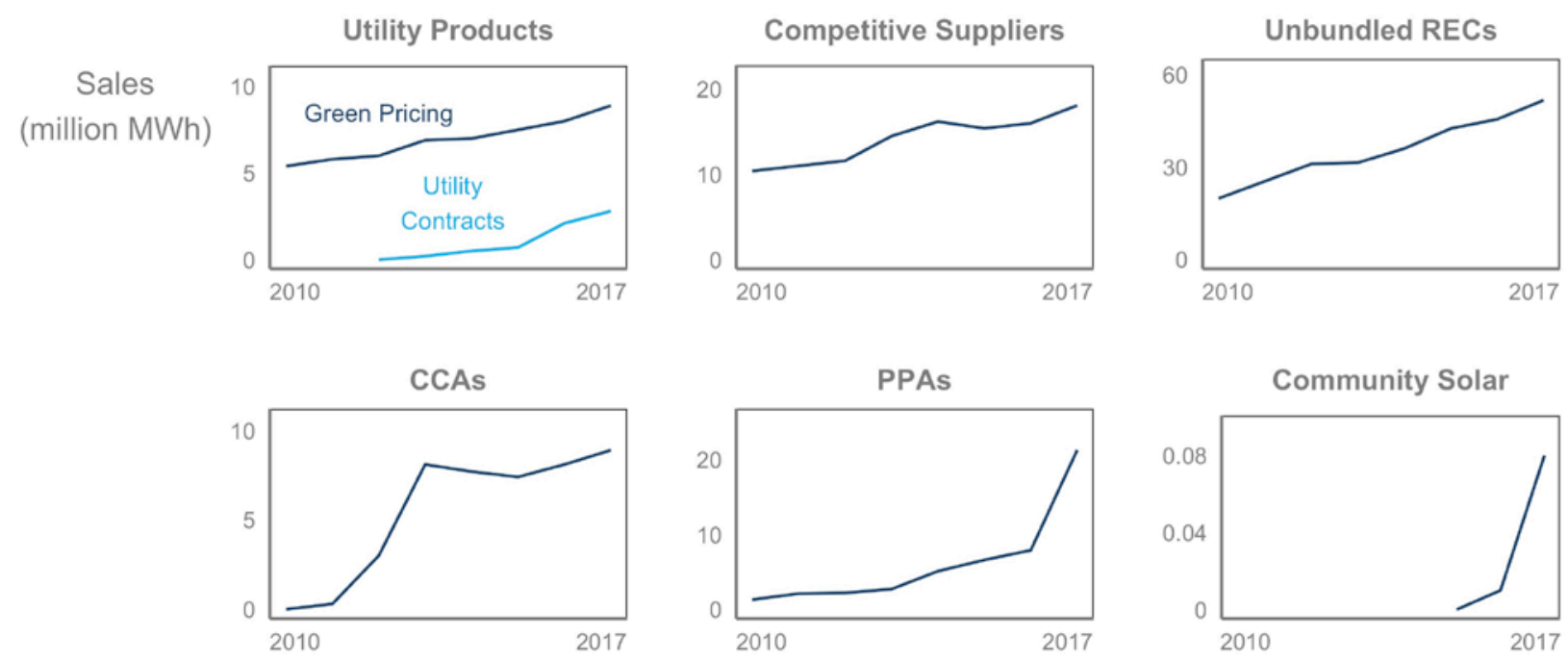

Figure 2. Green power sales by mechanism, 2010-2017

Plots are on different scales. 
We estimate that green power participation remained relatively stable from 2016 to 2017 , as increases in participation through most products were offset by an estimated reduction in competitive supplier customers (Table 5, Figure 3). Over that period, CCAs accounted for about half of all green power customers.

Table 5. Estimated Green Power Participation ( $\times 1,000$ customers $\left.^{\mathrm{a}}\right), 2012-2017^{\mathrm{b}}$

\begin{tabular}{lrrrrrr}
\hline Green power option & $\mathbf{2 0 1 2}$ & $\mathbf{2 0 1 3}$ & $\mathbf{2 0 1 4}$ & $\mathbf{2 0 1 5}$ & $\mathbf{2 0 1 6}$ & $\mathbf{2 0 1 7}$ \\
\hline Utility green pricing & 570 & 706 & 743 & 789 & 816 & 885 \\
Utility contracts & 0 & 0.001 & 0.001 & 0.001 & 0.001 & 0.002 \\
Competitive suppliers & 1,200 & 2,200 & 1,584 & 1,506 & 2,011 & 1,691 \\
Unbundled RECs & 110 & 95 & 89 & 70 & 108 & 192 \\
CCAs & 580 & 1,600 & 1,700 & 1,380 & 2,600 & 2,726 \\
PPAs & 0.15 & 0.17 & 0.18 & 0.20 & 0.21 & 0.27 \\
Community solar & 0 & 0 & 0 & 0 & 1.5 & 4.7 \\
\hline Total & $\mathbf{2 , 4 6 0}$ & $\mathbf{4 , 6 0 1}$ & $\mathbf{4 , 1 1 7}$ & $\mathbf{3 , 7 4 5}$ & $\mathbf{5 , 5 3 7}$ & $\mathbf{5 , 5 0 0}$ \\
\hline
\end{tabular}

a Includes all customer types: residential, C\&I, institutional

b We continuously update historical results based on improved data and methods; some historical results differ from results provided in previous versions of this report.
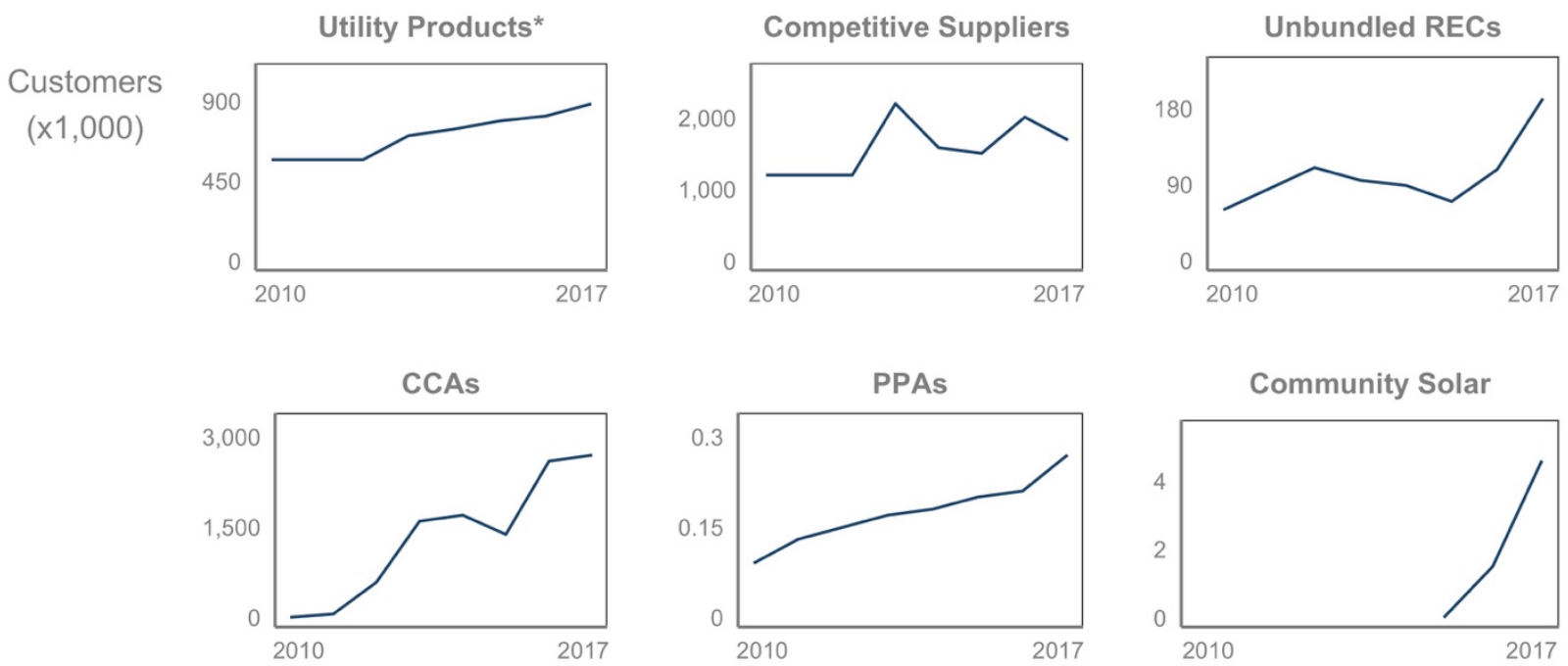

Figure 3. Green power participation by mechanism (2010-2017)
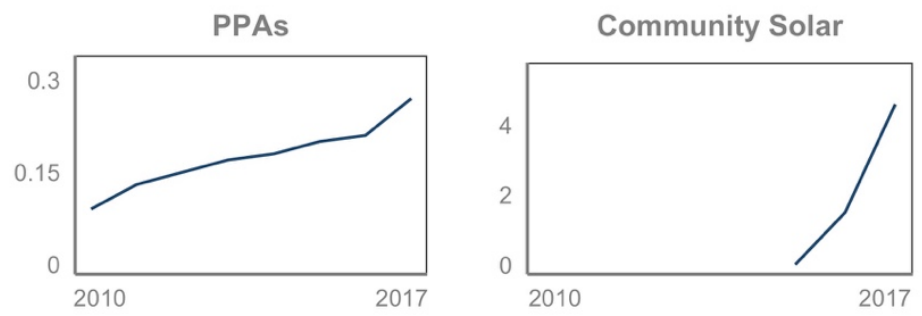

Plots are on different scales.

* Equal to sum of utility green pricing and utility renewable contracts 
Figure 4 places the voluntary green power market in the context of the broader renewable energy market, excluding large hydropower. Most U.S. renewable energy sales are used to comply with state RPS programs. In 2017, compliance-based sales in state programs that require regulated entities to procure RECs from "new" projects accounted for about $36 \%$ of renewable energy sales, while compliance-based sales from existing projects accounted for about $21 \%$ of renewable energy sales. The voluntary market accounted for about $26 \%$ of all U.S. nonlargehydro renewable energy sales in 2017. The "other renewables" group in Figure 4 includes utility renewable energy purchasing beyond RPS requirements and on-site generation. The other category may also include some renewable energy that was generated in 2017 for which the RECs will be sold in a future year. Compliance-based REC sales are based on data compiled by the Lawrence Berkeley National Laboratory (LBNL 2017). Total U.S. renewable energy sales are based on retail electricity sales data from the U.S. Energy Information Administration (EIA 2018b).

\section{Millions}

of MWh 400

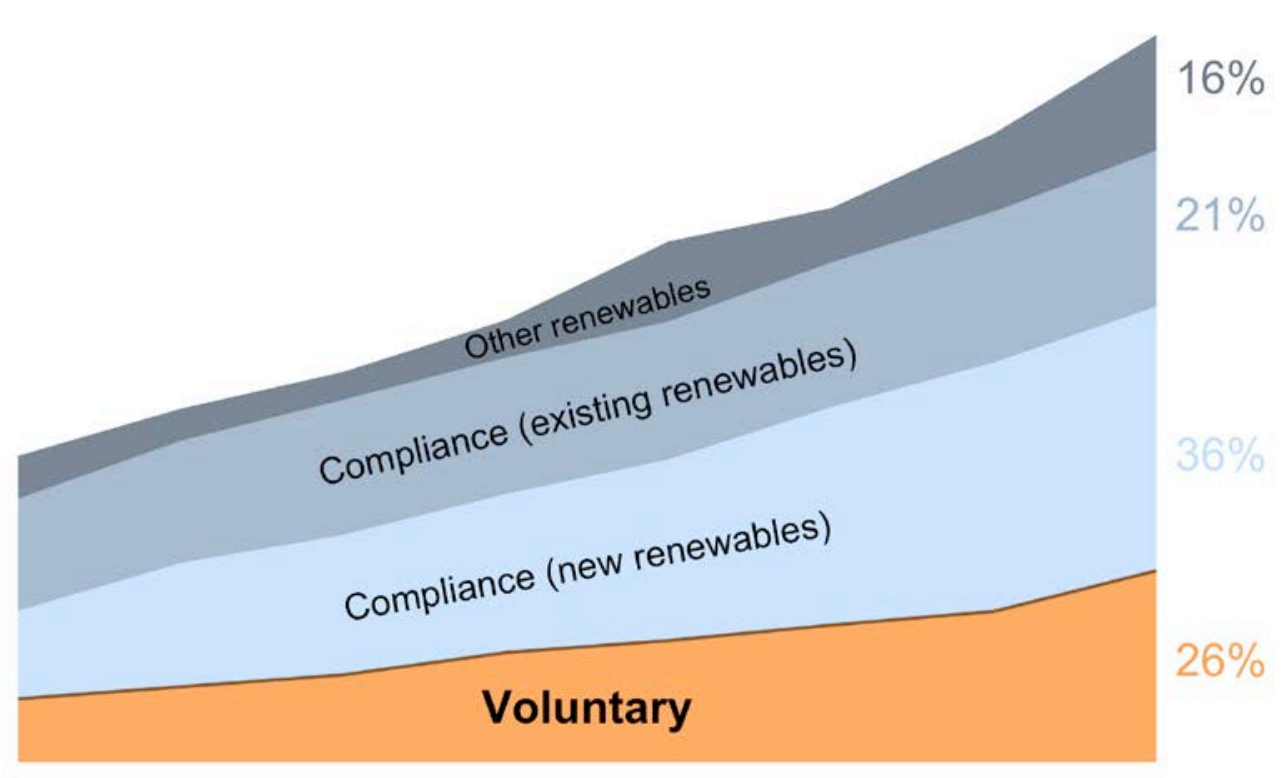

2010

2017

Figure 4. Renewable energy sales in voluntary, compliance, and other markets, 2010-2017

Based on data from EIA (2018b) and LBNL (2017)

The category of "other renewables" has expanded in recent years, in part because some utilities are exceeding RPS requirements as renewable energy costs fall. For instance, California's investor-owned utilities were on track to meet the state's previous RPS about 10 years ahead of schedule (Gattaciecca, Trumbull, and DeShazo 2018), and recent changes to the California RPS may prompt California utilities to further increase renewable energy procurement. Increased above-RPS renewable energy procurement by utilities could have implications for voluntary green power markets. We explore these questions as part of a larger discussion in Section 10. 


\section{Utility Green Pricing}

Many utilities sell green power to residential and nonresidential customers through utility green pricing programs (Figure 5). ${ }^{4}$ In a green pricing program, the utility retires RECs on behalf of the customer in proportion to the quantity of green power purchased by the customer. Green pricing customers generally pay for the green power through an additional line item on their utility bill. Green pricing sales and participation data in this report are based on survey data gathered by NREL.

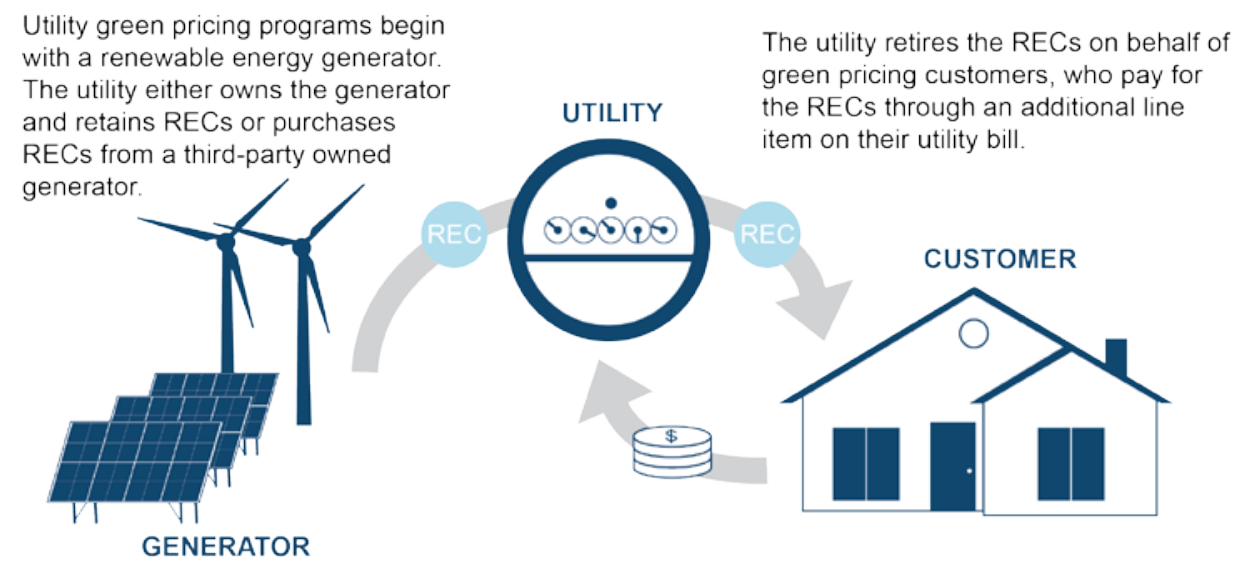

Figure 5. How utility green pricing programs work

The figure provides a simplified schematic for visualization purposes. Specific program structures vary.

\subsection{Status of Utility Green Pricing Programs}

In 2017, about 885,000 customers bought about 8.9 million MWh of green power through utility green pricing programs (Figure 6).
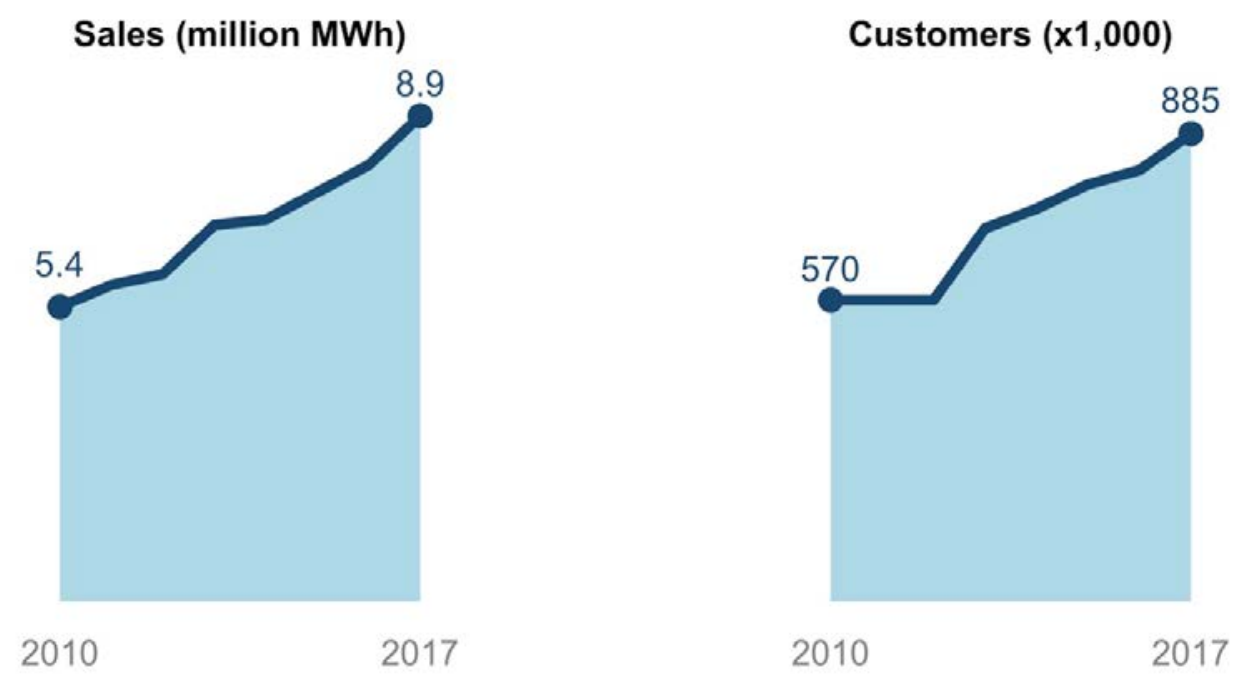

Figure 6. Utility green pricing program sales and participation, 2010-2017

\footnotetext{
${ }^{4} \mathrm{~A}$ list of active utility green pricing programs is available at https://www.nrel.gov/analysis/green-power.html ("Voluntary Green Power Procurement," NREL).
} 


\subsection{Trends in Utility Green Pricing Programs}

Utility green pricing sales continue to steadily increase. A few key trends have emerged alongside this steady increase in sales: growth continues to be driven by a few large programs; utility green pricing programs are increasing the solar content of their green power portfolios; green pricing premiums correlate with program size and renewable energy content; and programs continue to procure primarily unbundled RECs.

\section{Overall growth was driven by success in the largest programs}

Large green pricing programs steered overall sales and participation growth in 2017, consistent with previous years, overshadowing ongoing retraction of smaller programs. We estimate that the 10 largest utility green pricing programs accounted for about $90 \%$ of overall sales in 2017 . These large programs achieve their size, in part, because of high participation rates (i.e., the percentage of eligible customers that enroll in green pricing). For instance, Portland General Electric (PGE), the largest green pricing program in the country, reached a customer participation rate of over $19 \%$. The participation rate among the remaining top 10 programs averaged about $4 \%$ (NREL 2018), while participation rates outside the top 10 averaged around $2 \%$.

Residential and nonresidential sales both increased from 2016 to 2017 in the top 10 programs, while sales in both sectors stabilized in the remaining programs (Figure 7). After several years of decline, residential enrollment and sales in programs outside the top 10 programs remained steady over the course of 2017. Similarly, outside the top 10, nonresidential enrollment continued to decline but at a slower rate than previous years. The drivers behind the ongoing decline in nonresidential sales in the non-top 10 programs is unclear. Possible explanations include nonresidential customers shifting toward other green power products such as unbundled RECs, shifting toward other electricity products such as community solar that do not necessarily meet the definition of green power, or simply losing interest in green power.

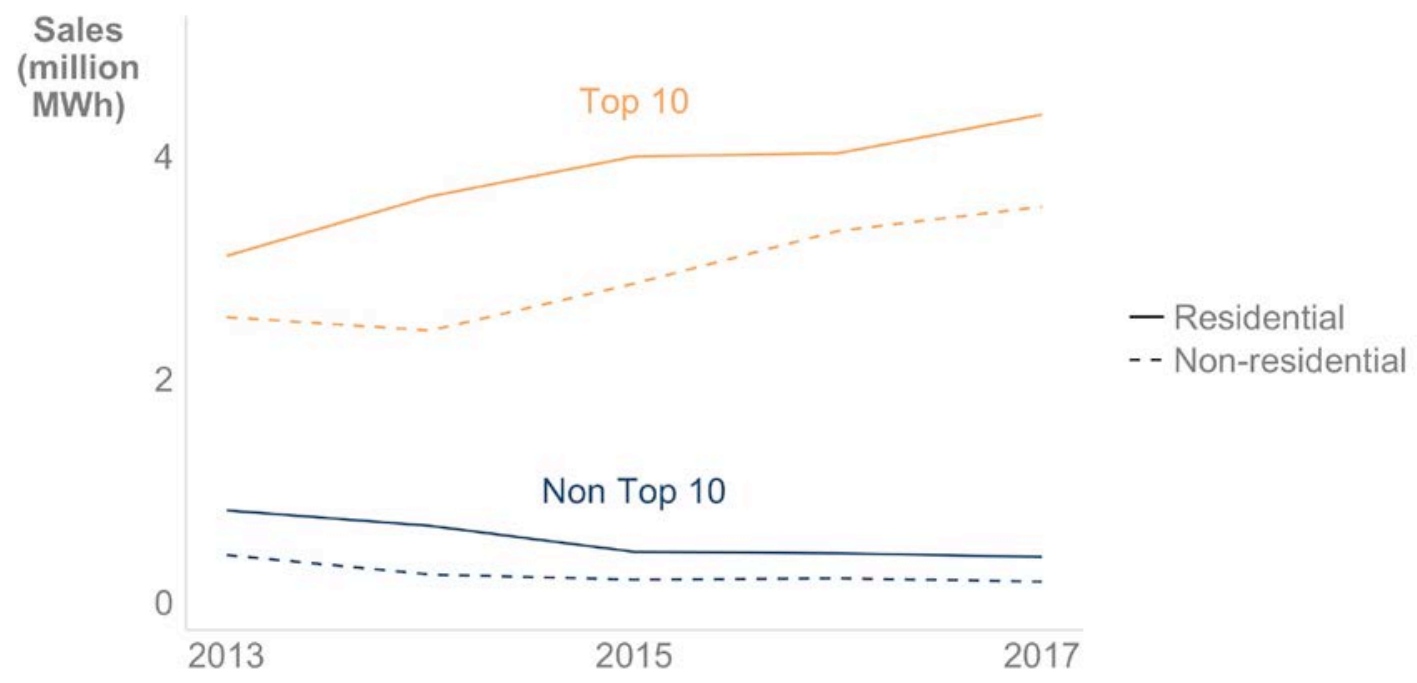

Figure 7. Residential and nonresidential utility green pricing sales in top 10 and other programs 


\section{Solar content continues to increase in green pricing portfolios}

Solar is increasing in its share of the power mix of green pricing programs, though wind remains the primary generation resource. This trend is largely driven by a few large programs that are beginning to increase procurement of solar resources. Emerging green pricing programs that feature solar procurement allow customers to purchase solar-generated RECs at a premium. Unlike utility-administered community solar, green pricing programs do not provide customers with bill credits for PV system output. Notably, several large utilities that offer green pricing programs initiated new solar programs in 2017 that provide both bill credits and RECs to customers. Though these programs blur the lines between green pricing and community solar, we define them here as community solar and summarize these projects in Section 9.2.2.

To our knowledge, PGE's Green Future Solar program, launched in 2015, remains the only green pricing program fueled entirely by solar. Green Future Solar customers purchase 1-kW "blocks" of solar energy for an additional $\$ 5$ per month on top of basic service. This program exhibited growth in both sales and enrollment from 2016 to 2017. Several other large programs increased the solar content of their green power portfolios in 2017, including PacifiCorp's Blue Sky Block, Xcel Energy's Renewable*Connect, the Tennessee Valley Authority's Green Power Switch Program, and Avista's Buck-A-Block program.

An increase in solar sales is particularly prominent among the top 10 utilities: the contribution of solar to green power sales in the top 10 programs reached $14 \%$ in 2017 , compared to $6 \%$ for other programs. However, the solar share in non-top 10 programs is increasing rapidly, growing from $1 \%$ in 2016 to $6 \%$ in 2017. Most remaining non-wind renewable generation outside the top 10 is sourced from landfill gas, which has remained steady at about $13 \%$ share of generation.

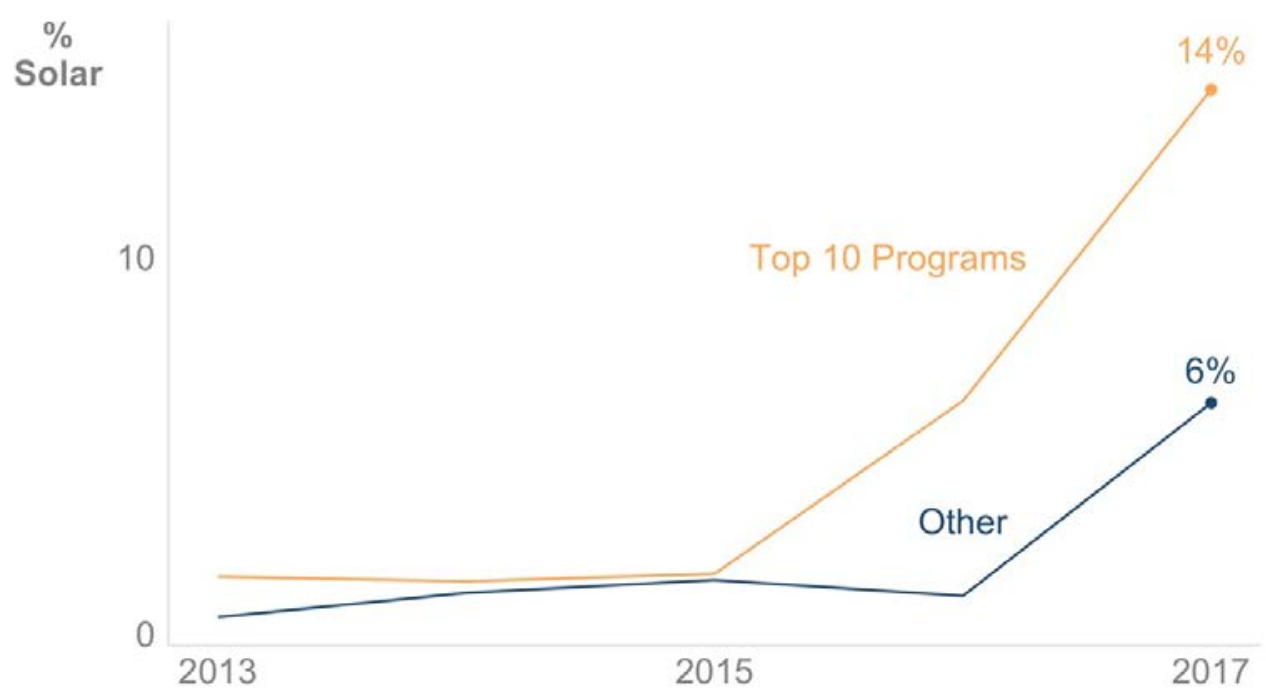

Figure 8. Percentage of solar in green power portfolios of top 10 and other utility green pricing programs

\section{Green pricing premiums correlate with program size and solar content}

Green pricing programs charge customers for their RECs through premiums over the standard rates paid by utility customers. These premiums are generally higher than prices for unbundled RECs (see Section 6) because green pricing programs must also recoup various program and 
administrative costs. Large green pricing programs generally offer green power at lower price premiums than other programs. The average residential premium among the top 10 programs was about $\$ 0.016 / \mathrm{kWh}$, while the average premium among other programs was $\$ 0.022 / \mathrm{kWh}$. Overall, residential rate premiums ranged from $\$ 0.002 / \mathrm{kWh}$ to $\$ 0.08 / \mathrm{kWh}$, with an overall average premium of $\$ 0.019$. The average nonresidential premium among top 10 programs was about $\$ 0.013 / \mathrm{kWh}$, while the average premium in smaller programs was about $\$ 0.022$. The ability of larger programs to offer lower green power premiums, possibly through economies of scale, helps explain why large green pricing programs have been able to sustain high participation rates, while smaller programs continue to exhibit losses in sales. Interestingly, utility green pricing premiums have remained relatively stable in recent years even as renewable energy costs have declined. Stable premiums may reflect stagnant utility administration and marketing costs that, unlike renewable energy costs, have not declined over time.

In addition to correlating with program size, green power premiums exhibit a slight correlation with the percentage of solar in the green power portfolio. Specifically, green power premiums are higher in green pricing programs that use more solar (Figure 9). This correlation is to be expected: solar is generally costlier per watt installed than wind, thus solar RECs are generally more expensive than wind-based RECs (see Section 6.2). The fact that some utility green pricing programs have been able to integrate more solar - despite its typically higher cost - may demonstrate customer interest in and willingness to pay for solar green power products.

\section{Average Premium $(\$ / \mathrm{kWh})$}

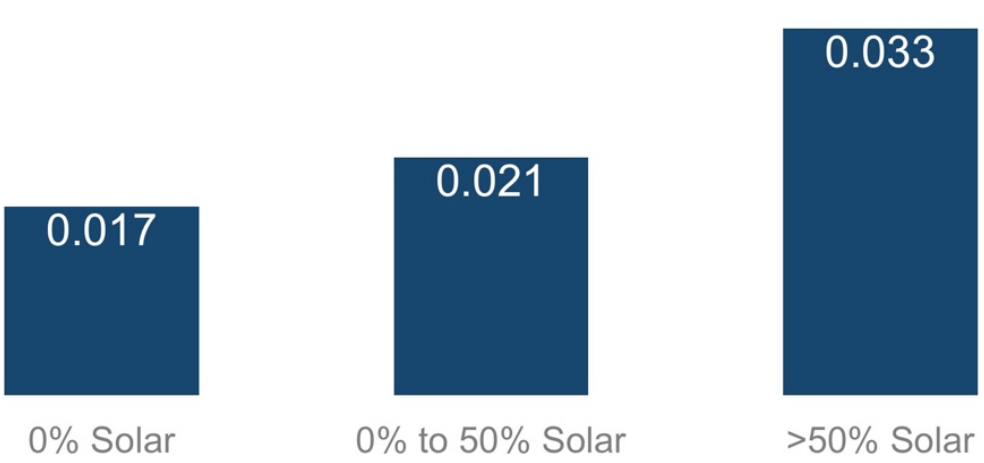

Figure 9. Average green pricing premium for programs offering different percentages of solar

\section{Green Pricing Programs Continue to Procure Primarily through Unbundled RECs}

Unbundled RECs remain the leading method for green power procurement in utility green pricing programs. ${ }^{5}$ Across all utilities, about $52 \%$ of power is procured through unbundled REC contracts of five years or less. More utilities procured power through long-term bundled REC contracts in 2016 than 2017; in 2017, programs procured about $30 \%$ of green power through long-term ( $\geq 11$ years) bundled REC contracts, compared to $18 \%$ of power in 2016 . Green power procured through utility-or customer-owned generation is marginal and shows a decrease compared to prior years.

\footnotetext{
${ }^{5}$ As noted in the introduction, unbundled RECs that are bought and sold by an intermediary like a utility green pricing program are excluded from the sales estimates for unbundled RECs summarized in Section 6.
} 
Table 6. Contract Length by Type of Utility Green Power Procurement (MWh), 2017

\begin{tabular}{lcccc}
\hline $\begin{array}{l}\text { Contract } \\
\text { Length }\end{array}$ & $\begin{array}{c}\text { Unbundled } \\
\text { RECs (\%) }\end{array}$ & $\begin{array}{c}\text { RECs Bundled with } \\
\text { Electricity (\%) }\end{array}$ & $\begin{array}{c}\text { Projects Owned by } \\
\text { Utility (\%) }\end{array}$ & $\begin{array}{c}\text { RECs Produced by } \\
\text { Utility Consumers (\%) }\end{array}$ \\
\hline 1 year & 28 & 0 & 0 & 0 \\
$2-5$ years & 24 & 0 & 0 & 0 \\
$6-10$ years & 3 & 6 & 0 & $\sim 0$ \\
$\geq 11$ years & 4 & 30 & 5 & 0 \\
\hline Percent of total & 59 & 36 & 5 & 0 \\
procurement & 59 & & \\
\hline
\end{tabular}




\section{Utility Renewable Contracts}

Some utilities offer to procure renewable energy on behalf of large nonresidential customers through a one-off bilateral contract or through programs known as utility green tariffs. In both cases, the utility moves the customer to a new rate structure to reflect the costs of the renewable energy project and retires RECs on behalf of the customer. A key difference between utility renewable contracts and utility green pricing is that customers may use utility renewable contracts to support and procure green power from a new generator. Also, the long-term price predictability of utility renewable contracts may yield economic benefits that do not accrue through utility green pricing programs.

In a utility renewable contract, the customer enters into a contract with the utility to procure power and RECs from a renewable energy provider. Unlike green pricing programs, the customer may be able to specify the resource for the product.
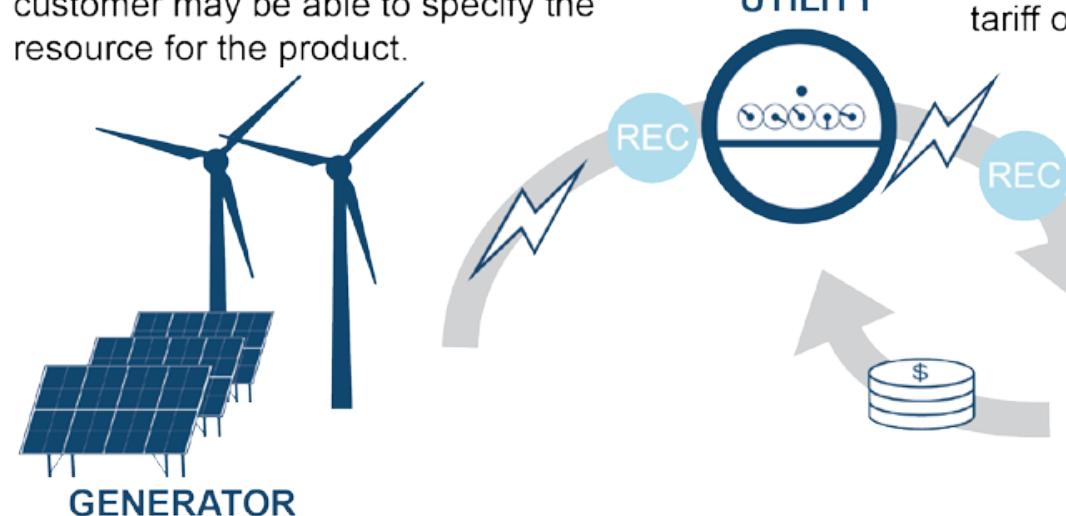
The utility provides the power and RECs to the customer. The customer continues to pay the utility with a modified green tariff or bilateral contract rate.

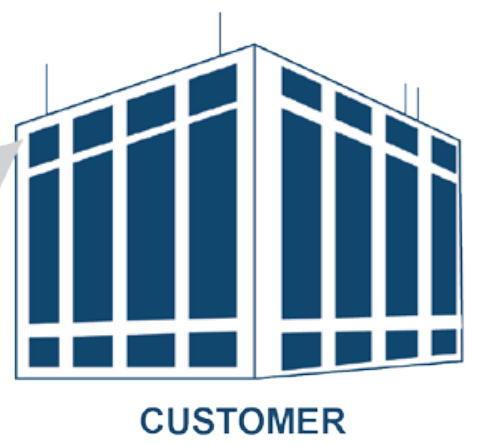

Figure 10. How utility renewable contracts work

The figure provides a simplified schematic for visualization purposes. Specific program structures may vary; tariff structures may also vary within programs on a case-by-case basis.

\subsection{Utility Bilateral Agreements}

In a bilateral agreement, a utility procures renewable energy on behalf of a single nonresidential customer through a one-off contract. The terms of bilateral agreements are generally unavailable to other customers; hence, bilateral agreements may vary from project to project even within the same utility. Bilateral agreements can be difficult to track, because capacity may not be publicly disclosed. Based on data compiled in Heeter, Cook, and Bird (2017) and on subsequent NREL research, we estimate that at least 15 utility bilateral agreements have been signed in nine states: Alabama, Arizona, Georgia, Iowa, Kentucky, Nebraska, Oklahoma, Oregon, and Tennessee. We estimate that about $741 \mathrm{MW}$ of capacity in six agreements had come online by the end of 2017 and that they generate about 2.2 million MWh of green power per year (Figure 11). Most bilateral agreements to date have been made by information technology companies (e.g., Google and Microsoft), allowing these companies to power data centers with green power located in their utility's service territory. Iowa is the state leader in terms of bilateral contract capacity due to two relatively large wind contracts totaling to about $546 \mathrm{MW}$ of capacity. 


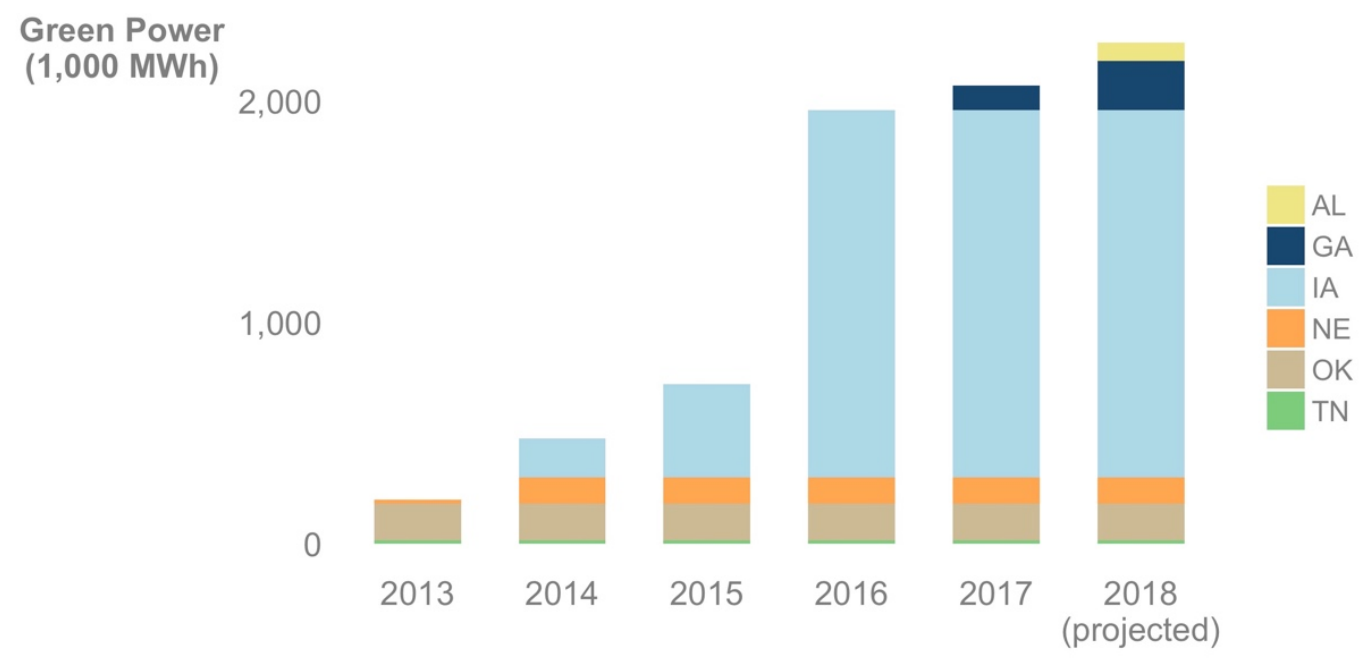

Figure 11. Annual green power sales through utility bilateral contracts

Based on data from Heeter, Cook, and Bird (2017) and data collected by NREL

\subsection{Utility Green Tariff Programs}

Utility green tariff programs allow customers to switch to new tariff rates to procure renewable energy via the utility. Utility green tariffs are available to any customer in an eligible customer class, whereas bilateral contracts are one-off arrangements with a single customer. Much like a utility green pricing program, this is a program run through the utility but typically involves a larger customer purchase. Further, most utility green pricing customers remain on the same rate structure and pay an additional line-item premium to reflect their participation in green pricing. In contrast, utility green tariff customers switch to a new rate structure to reflect their participation in the green tariff.

Fourteen utilities currently offer green tariff programs, though customers have only used the green tariffs under 10 of these programs (WRI 2018) (Figure 12). By the end of 2018, 21 green tariffs are expected to be offered by 16 utilities in 17 states (Bonugli et al. forthcoming). Some programs are limited to new load, meaning that customers can only use the green tariffs to procure electricity for new facilities or operations (e.g., New Mexico, North Carolina). Some programs place restrictions on the use of green tariffs for existing customers. For instance, the Madison Gas \& Electric program in Wisconsin only allows existing customers to use green tariffs for projects no larger than $25 \mathrm{MW}$ in capacity but places no restrictions on new customers (Tawney, Barua, and Bonugli 2017). 


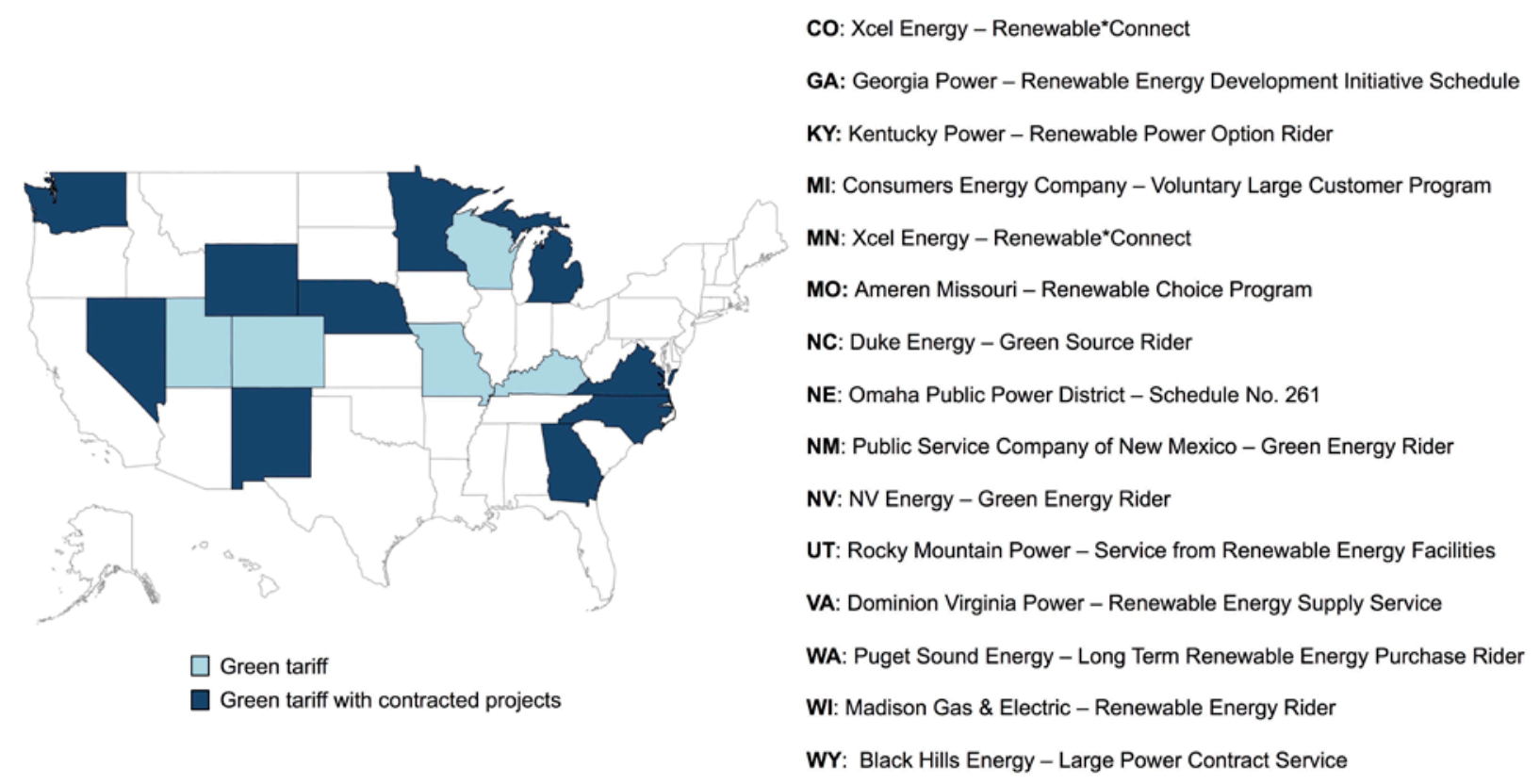

Figure 12. Utility green tariff programs

Map based on information from WRI (2018)

By the end of 2017, $770 \mathrm{MW}$ of PV projects had been contracted for through green tariff programs, with about $540 \mathrm{MW}$ of that capacity in nine projects online by the end of 2017 . We estimate these projects generated about 716,000 MWh of green power in 2017. We project that green power output will increase to 1,037,000 MWh in 2018 (Figure 13), both because projects that came online in the middle of 2017 will produce for the entire calendar year, and also because three additional projects are slated to come online in 2018 (WRI 2018). Nevada is currently the state leader in terms of green power output from utility green tariffs, in part because NV Energy's program is the longest-running utility green tariff in the country, implemented in September 2013.

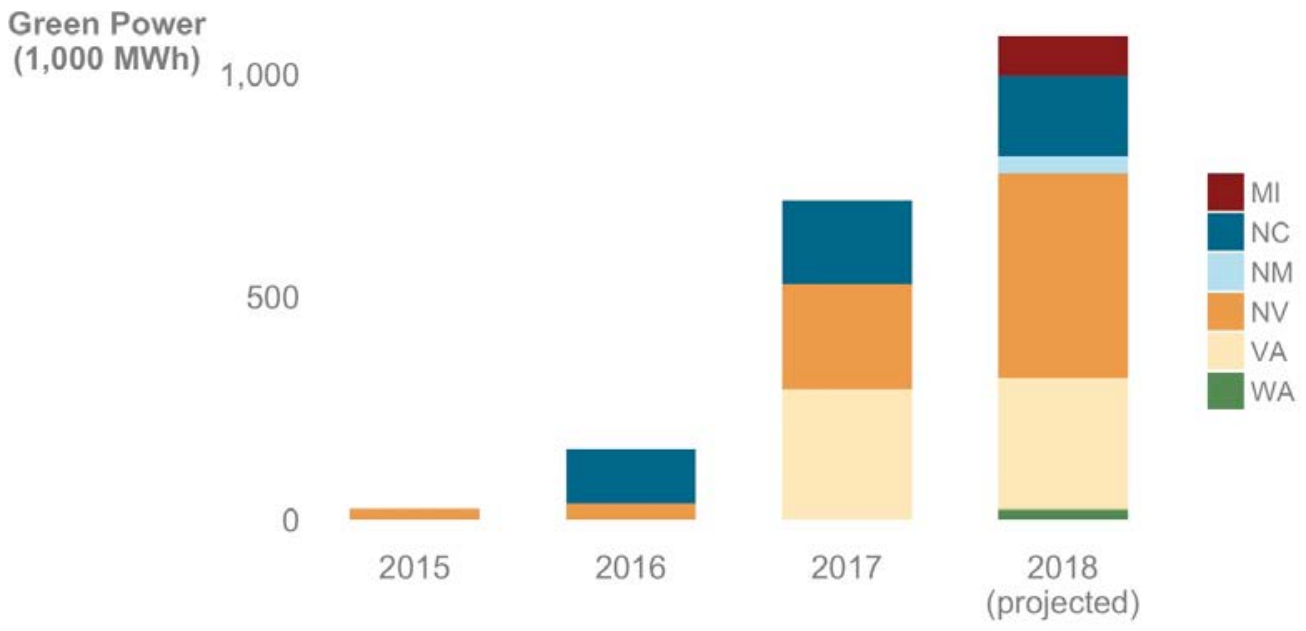

Figure 13. Annual green power sales through utility green tariff programs

Based on data from WRI (2018) 


\section{Competitive Suppliers}

In states with restructured electricity markets, ${ }^{6}$ retail electricity customers can choose to buy electricity from a number of providers known as competitive suppliers (Figure 14). Many customers choose to switch to competitive suppliers that offer green power products.

In restructured electricity markets, customers may choose a competitive electricity supplier that offers a green power product.

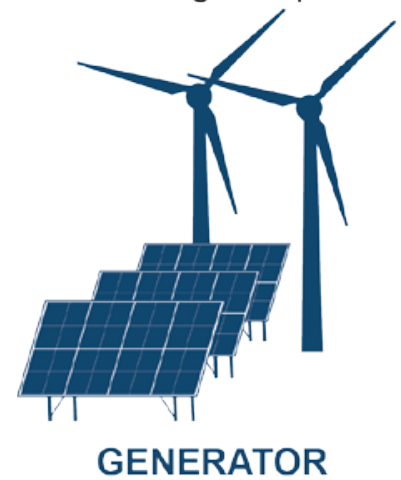

GENERATOR
The competitive supplier provides the customer with power and RECs. The utility remains responsible for transmission and distribution. The competitive supplier may charge a premium for the green power product.

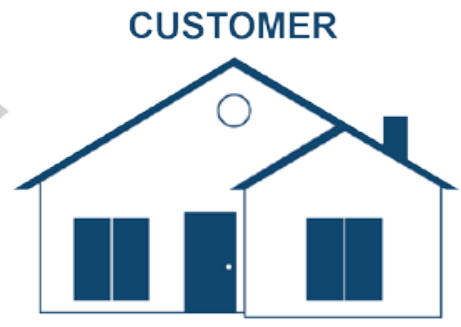

Figure 14. How competitive suppliers work

The figure provides a simplified schematic for visualization purposes. Specific transactions may vary.

\subsection{Status of Competitive Supplier Green Power}

In 2017, competitive suppliers sold about 18.1 million MWh of renewable energy to about 1.7 million customers (Figure 15).

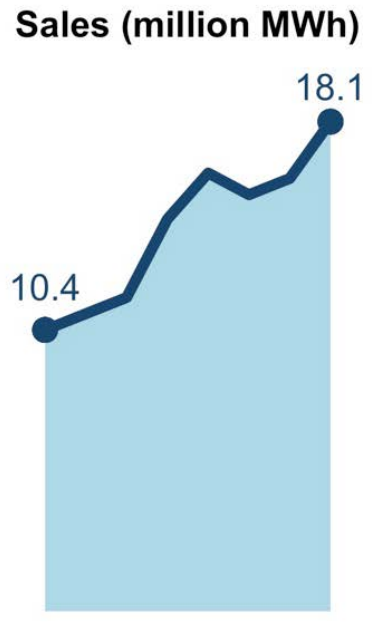

2010
2017
Customers $(x 1,000)$

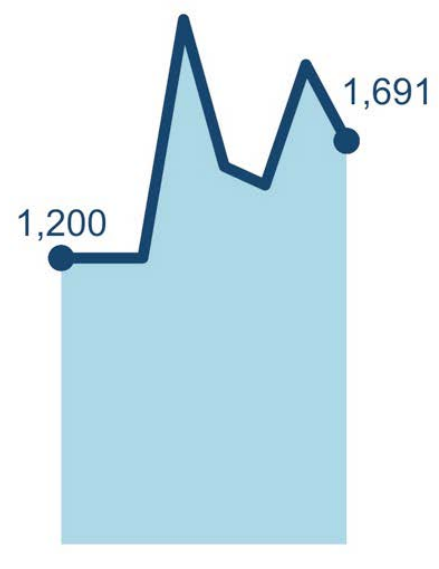

2010
2017

Figure 15. Competitive supplier sales and participation, 2010-2017

\footnotetext{
${ }^{6}$ The term "restructured" refers to markets where non-utility suppliers are allowed to compete with utilities to supply retail electricity. 15 states currently have fully restructured retail electricity markets: CT, DE, IL, MA, MD, ME, MI, NH, NJ, NY, OH, OR, PA, RI, TX.
} 


\subsection{Trends in Competitive Supplier Green Power}

Similar to trends in utility green pricing, we estimate that steady growth in competitive supplier green power sales is primarily attributable to a few large suppliers. Figure 16 depicts green power sales for eight suppliers that offer $100 \%$ renewable energy products and had data reported in EIA Form-861 in every year from 2014 to 2017 (EIA 2018a). ${ }^{7}$ The figure shows how the top suppliers increased green power sales by around 1.6 million MWh from 2014 to 2017. These trends suggest large suppliers are finding ways to increase green power sales, possibly through economies of scale. In contrast, we estimate that the remainder of the market has stagnated, with sales increasing by about 0.3 million MWh from 2014 to 2017 . Over $90 \%$ of the sales of the top suppliers occurred in Texas (80\%), New York (7\%), Pennsylvania (5\%), Ohio (2\%), and Illinois $(2 \%)$.

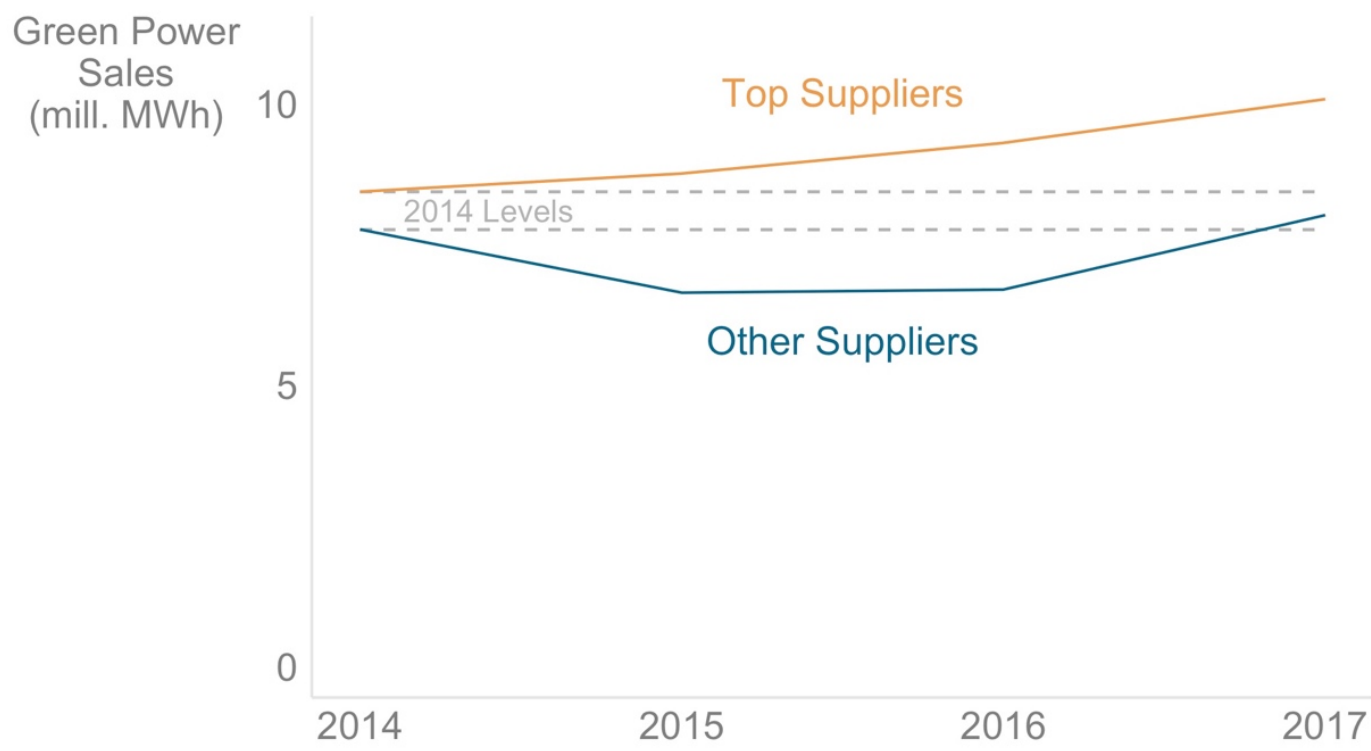

Figure 16. Competitive supplier green power sales by top eight suppliers and other suppliers

\footnotetext{
${ }^{7}$ Breeze; Collegiate Clean Energy; Green Mountain Energy; Kiwi Energy; MPower Energy; Spartan Renewable Energy; SmartEnergy Holdings; Star Energy Partners.
} 


\section{Unbundled RECs}

When a renewable energy generator produces a megawatt-hour of output, the electricity may be sold into a wholesale electricity market while the REC is "unbundled" and sold into a separate REC market (Figure 17). This section provides data on sales of unbundled RECs directly to enduse customers. This section excludes sales of unbundled RECs through other green power products such as utility green pricing programs, competitive suppliers, and CCAs.

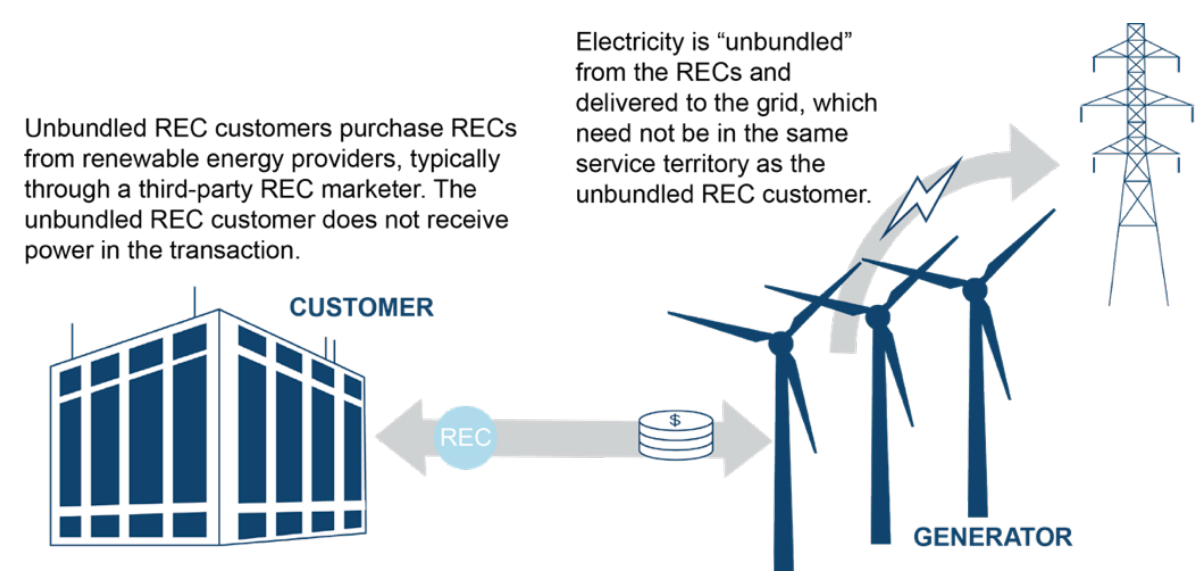

Figure 17. How unbundled RECs work

The figure provides a simplified schematic for visualization purposes. Specific transactions may vary.

\subsection{Status of Unbundled RECs}

We estimate that about 192,000 customers bought about 51.8 million MWh of green power directly through unbundled RECs in 2017 (Figure 18).

\section{Sales (million MWh)}

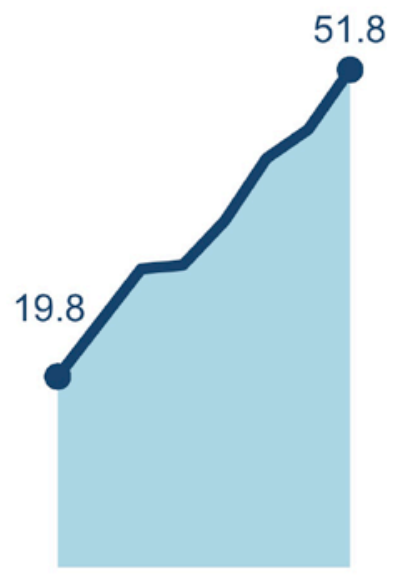

2010
2017

\section{Customers $(x 1,000)$}

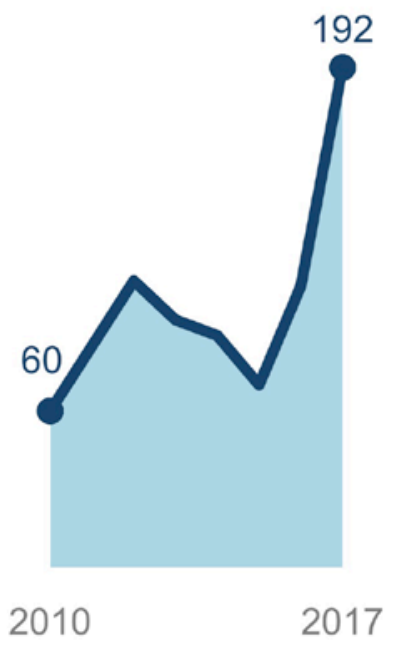

Figure 18. Unbundled REC sales and participation, 2010-2017 


\subsection{Trends in Unbundled RECs}

Unbundled RECs have historically been procured through relatively large bulk purchases. As recently as 2015, the average unbundled REC customer procured about $610 \mathrm{MWh}$ of unbundled RECs per year. For comparison, a typical residential home uses around $10 \mathrm{MWh}$ per year. Beginning in 2016 and continuing in 2017, the average unbundled REC purchase size declined as more residential and small commercial customers began to procure unbundled RECs. The average unbundled REC purchase fell to $420 \mathrm{MWh}$ per customer in 2016 and to $270 \mathrm{MWh}$ per customer in 2017. The trend toward smaller unbundled REC purchases may reflect the successful efforts of REC providers to market unbundled RECs to smaller green power customers.

Relatively low REC prices are one contributing factor to ongoing increases in unbundled REC sales. From 2014 to 2017 , REC prices fell by more than $50 \%$, corresponding to a period of rapidly increasing unbundled REC sales. For the first time since 2013, prices for voluntary RECs increased for consecutive months in 2018 (Figure 19). Voluntary REC prices increased from $\$ 0.31 /$ MWh in August 2017 to $\$ 0.70 /$ MWh in August 2018. The recent increase in REC prices could reflect a market adjustment to the increasing demand for unbundled RECs. However, voluntary REC prices still remain below 2014 levels.

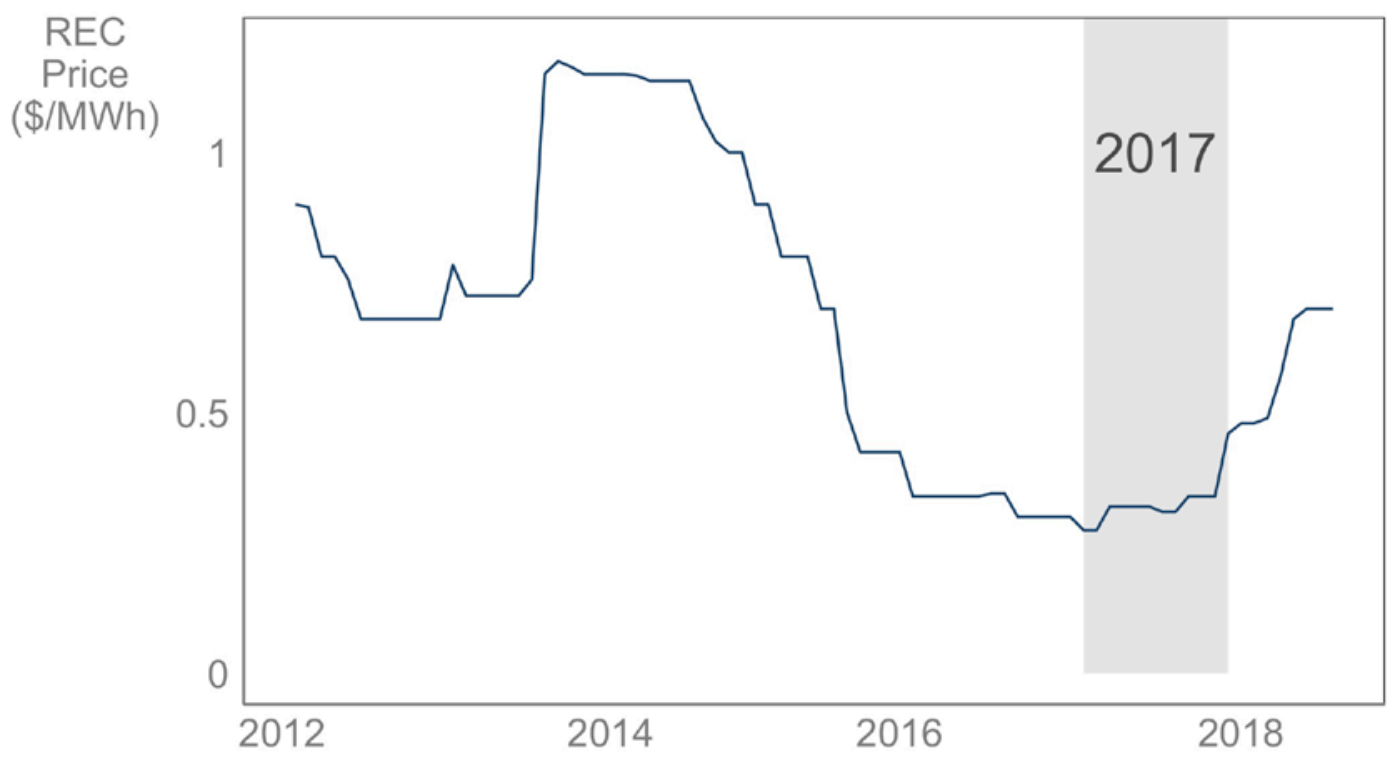

Figure 19. Voluntary national REC prices, January 2012-August 2018

Based on data from Spectron (2018)

For additional context, the following two figures provide information about REC pricing for compliance-based RECs. RECs used for RPS compliance have different pricing than RECs used for voluntary purposes. Prices for RECs used for compliance purposes tend to be higher due to RPS programs that require regulated entities to source RECs from specific states or regions. These restrictions limit the supply of eligible RECs while ensuring demand from load-serving entities, causing upward pressure on prices for RECs. This upward pressure on REC prices translates to higher prices for compliance-based and voluntary RECs in states with RPS. As a result, RECs (both compliance-based and voluntary) tend to exhibit higher prices in the states 
with the strictest RPS requirements and lower prices in states with low or no RPS. As illustrated in the following figures, REC prices can be volatile due to changing RPS policies (Barbose 2017). For a more thorough discussion of compliance REC prices and trends see Barbose (2017).

Figure 20 illustrates REC prices for 12 states with sufficient data aggregated by SNL Energy (2018), excluding solar RECs (SRECs). The decline in REC prices in the northeastern states is attributable to increasing supplies in the region (Barbose 2017).
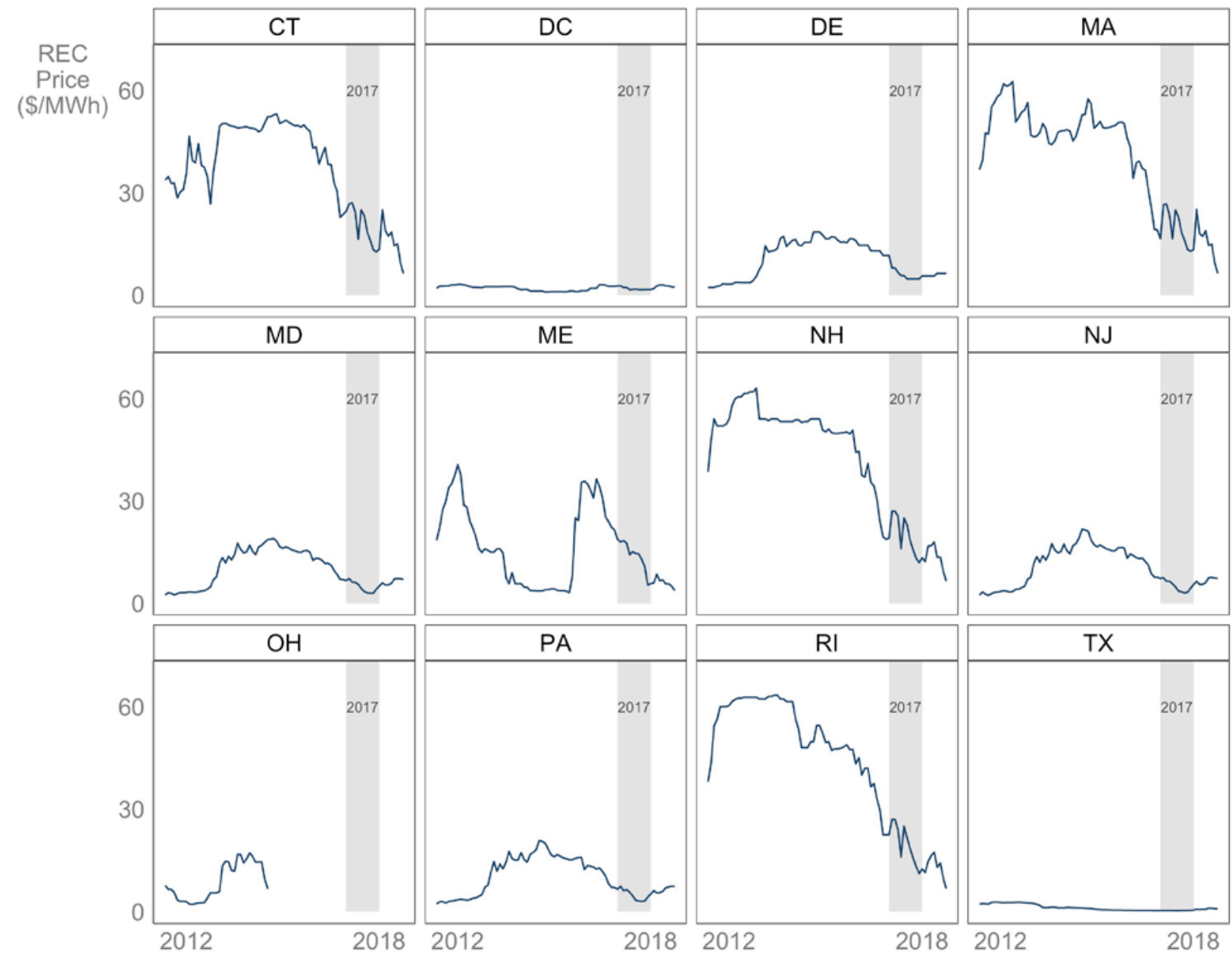

Figure 20. Prices of RECs used for compliance (excluding SRECs), January 2012_August 2018

Based on data from SNL Energy (2018)

The Ohio RPS program was frozen in 2015 and 2016. 
Figure 21 displays trends in prices for SRECs for states with active SREC markets. SREC prices tend to be significantly higher than other REC prices, on the order of hundreds rather than tens of dollars. Washington, DC has generally been the highest-priced SREC market in the country, due to the District's solar carveout combined with the challenges of finding adequate PV host sites in a predominantly urban jurisdiction. However, Massachusetts surpassed DC as the most expensive SREC market in August 2018, as SREC prices in DC fell sharply and Massachusetts SREC prices increased beginning in April 2018. The recent increase in Massachusetts SREC prices may reflect a market adjustment to the expiration of the state's existing SREC program in April 2018.

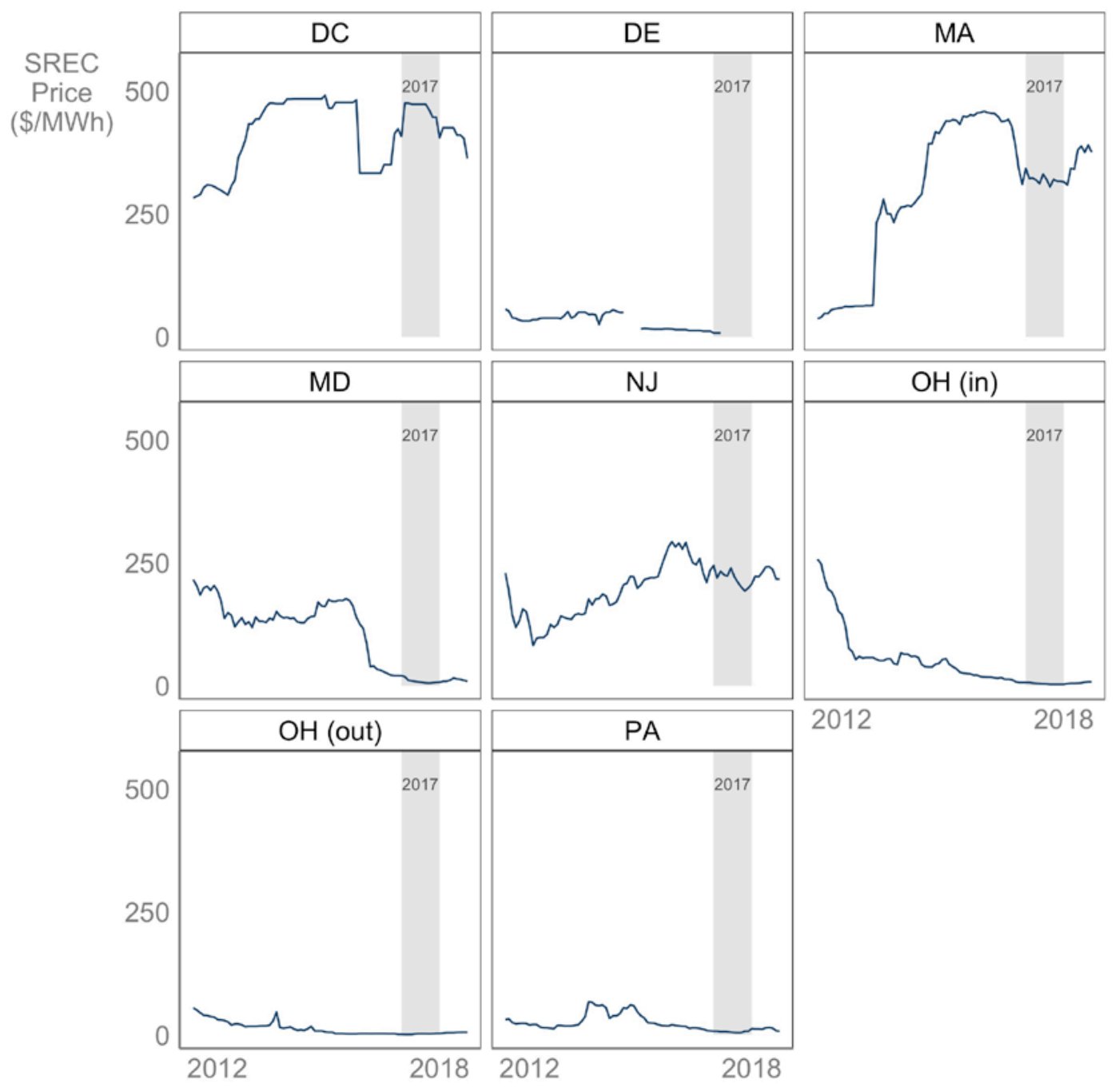

Figure 21. SREC pricing, January 2012-August 2018

Based on data from SNL Energy (2018). OH (in) refers to SREC prices in Ohio for in-state solar generation, while Ohio (out) refers to SREC prices in Ohio for out-of-state solar generation 


\section{Community Choice Aggregation}

A community choice aggregation (CCA) is a governmental entity that procures electricity on behalf of retail electricity customers (Figure 22). CCAs can only exist within an investor-owned utility territory. Some CCAs choose to procure green power on behalf of their customers above and beyond state RPS requirements, though most CCAs only procure as much renewable energy as required by state RPS. This section only reports data on green power sales through CCAs. Unlike every other green power product, CCAs are "opt out," meaning customers are notified about the program, given the choice of opting out, and then automatically enrolled into the CCA unless they choose to opt out of the program and return to the investor-owned utility.

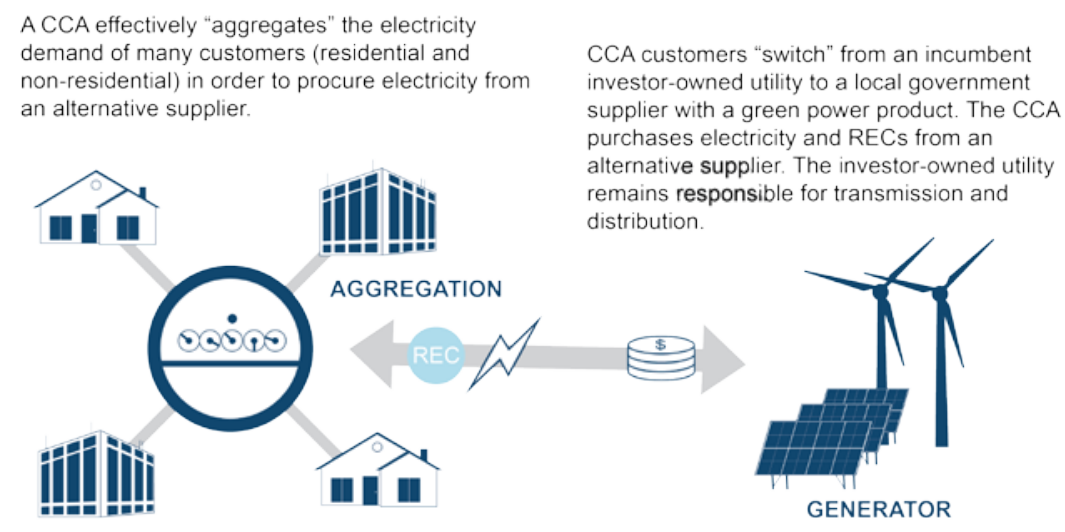

Figure 22. How community choice aggregation works

The figure provides a simplified schematic for visualization purposes. Specific program structures may vary.

\subsection{Status of CCAs}

In 2017, community choice aggregations sold about 8.9 million MWh of green power to about 2.7 million customers (Figure 23) in five states: California, Illinois, Massachusetts, New York, and Ohio.
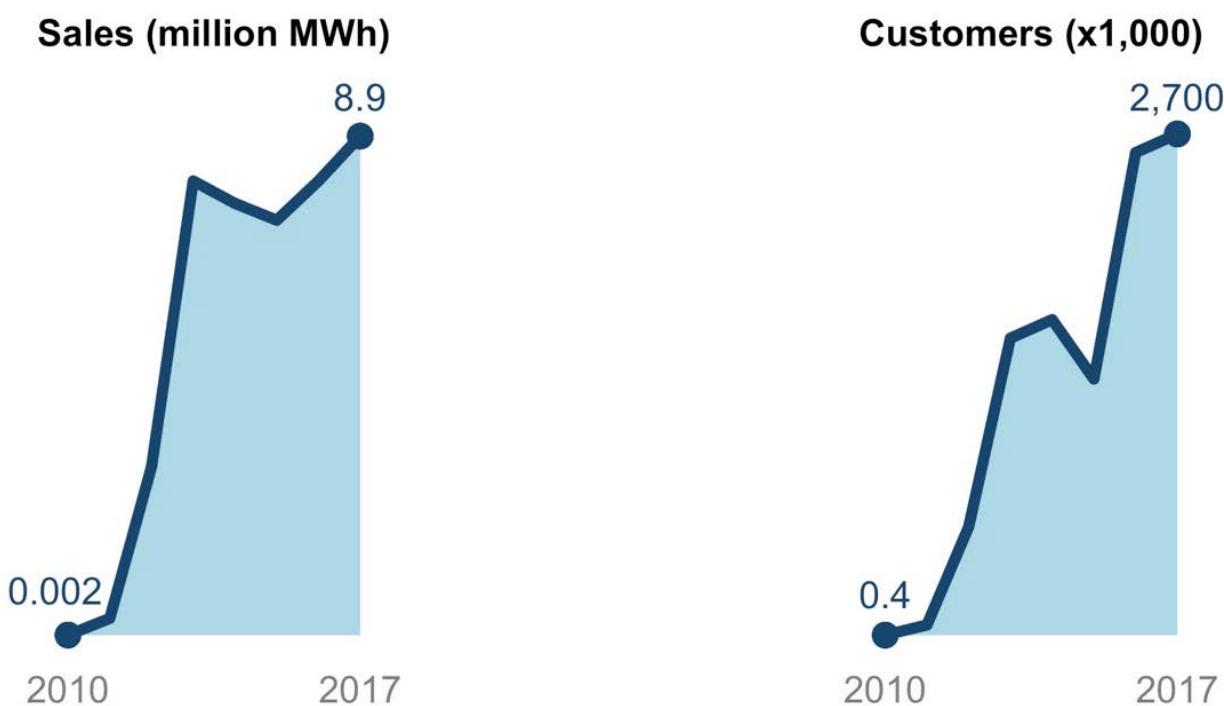

Figure 23. CCA sales and participation, 2010-2017 


\subsection{Trends in CCAs}

Illinois remains the top state-level CCA green power market in terms of sales, though California is now by far the state leader in terms of CCA green power participation (Table 7). California will likely surpass Illinois in terms of green power sales in 2018, as CCA green power programs continue to shrink in Illinois and expand in California.

Table 7. CCA Green Power Sales and Participation by State, 2017

\begin{tabular}{lccc}
\hline \multicolumn{1}{c}{ State } & $\begin{array}{c}\text { Estimated Green Power } \\
\text { Sales (MWh) }\end{array}$ & $\begin{array}{c}\text { Participants in CCAs with } \\
\text { Green Power Products }\end{array}$ & $\begin{array}{c}\text { CCAs with Green } \\
\text { Power Products } \\
\text { (as of 12/31/17) }\end{array}$ \\
\hline Illinois $^{\mathrm{a}}$ & $3,511,000$ & 463,000 & 50 \\
\hline California $^{\mathrm{b}}$ & $3,288,000$ & $1,239,000$ & 9 \\
\hline Massachusetts $^{\mathrm{c}}$ & $1,178,000$ & 400,000 & 35 \\
\hline Ohio $^{\mathrm{c}}$ & 573,000 & 100,000 & 2 \\
\hline New York $^{\mathrm{d}}$ & 332,000 & 64,000 & 1 \\
\hline Total $^{\mathrm{e}}$ & $\mathbf{8 , 8 8 3 , 0 0 0}$ & $\mathbf{2 , 7 2 6 , 0 0 0}$ & $\mathbf{9 7}$ \\
\hline
\end{tabular}

a Estimate extrapolated from publicly available reports of green power products in CCAs applied to historical data on electricity usage; ${ }^{b}$ Based on data obtained from California Energy Commission and compiled by the UCLA Luskin Center for Innovation (Trumbull 2018); ' Based on survey data; d Based on data from Westchester Power (2018);

e Figures do not perfectly add due to rounding

As shown in Figure 23, CCA sales increased sharply from 2010 to 2013 and then fell from 2013 to 2015, and they have since rebounded and had surpassed 2013 levels by 2017 . The 2013-2015 decline in CCA green power sales was driven by falling sales in Illinois and to a lesser extent in Ohio (Figure 24). At the same time, CCA green power sales steadily increased in California and Massachusetts. From 2015 to 2017, significant increases in green power sales in California and Massachusetts more than offset further sales reductions in Illinois and Ohio, driving an overall increase in CCA sales from 2015 to 2017. The implementation of a CCA in New York further contributed to increasing CCA green power sales. In the remainder of this section, we explore the state-level dynamics that explain these trends. 


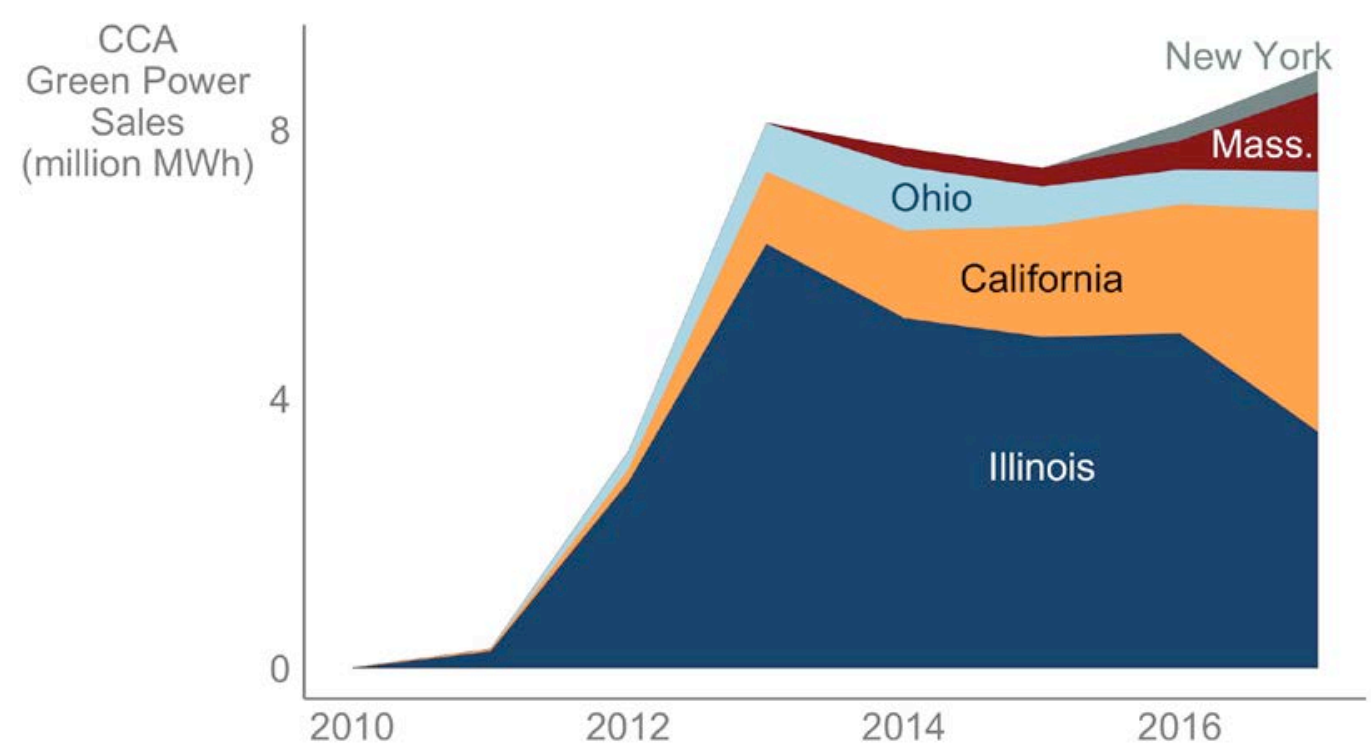

Figure 24. CCA green power sales (million MWh) by state

\section{California}

CCAs in California have expanded rapidly across the state and this expansion is accelerating. According to Gattaciecca, Trumbull, and DeShazo (2018), three communities implemented CCAs from 2010 to 2015, two communities implemented CCAs in 2016, four communities implemented CCAs in 2017, and eight additional communities are expected to implement CCAs by the end of 2018. We estimate that California CCA green power customers now outnumber CCA green power customers in all other states combined, and we project California will surpass Illinois as the leading state in terms of green power sales in 2018.

California is largely unique among the seven states that allow CCAs for two reasons. First, it has a regulated retail electricity market, meaning most retail electricity customers cannot procure power from competitive suppliers and are served exclusively by investor-owned or municipal utilities. ${ }^{8}$ As a result, California CCAs incur additional responsibilities not borne by CCAs in other states. In California, CCAs will be required to ensure reliable electricity service by entering into long-term (e.g., 10 years) contracts with generators for the RPS portion of their renewable energy procurement, beginning in 2021 (Gattaciecca, Trumbull, and DeShazo 2018). In contrast, CCAs in other states primarily sign short-term (e.g., three years) contracts with competitive suppliers. The ability/requirement to sign long-term contracts represents both a challenge and a benefit in terms of CCA green power procurement. New California CCAs may face challenges in entering long-term contracts, such as lack of financial standing and creditworthiness. On the other hand, long-term contracts may allow CCAs to more effectively procure new local renewable energy generation, create more rate stability, and ensure programmatic longevity. Indeed, by 2018, California CCAs had procured more than 1,000 MW of in-state renewable energy capacity through long-term contracts (CalCCA 2018), though some of this procurement may be used to meet RPS.

\footnotetext{
${ }^{8}$ Some large non-residential customers are allowed "direct access" to wholesale markets, but residential and small commercial retail customers cannot participate.
} 
Second, CCAs tend to be much larger in California than in the other states. On average, green power CCAs in California serve about 140,000 customers, compared to about 11,000 customers in Massachusetts and 9,000 customers in Illinois. The large size of California's CCAs stems from the prevalent use of joint powers agreements, ${ }^{9}$ contractual structures allowing a single entity to procure power on behalf of many municipalities. Through joint powers agreements, several CCAs in California serve entire counties and three CCAs serve multiple counties. By allowing CCAs to serve broader customer bases, joint powers agreements may yield economies of scale and allow CCAs to offer more services, such as electric vehicle charging programs, demand response, and energy efficiency programs (Gattaciecca, Trumbull, and DeShazo 2018).

\section{Illinois}

Green power sales through Illinois CCAs continue to decline due to discontinued green power programs; they fell $29 \%$ from 2016 to 2017 , both because some CCAs have discontinued entirely and because some CCAs have switched to lower-cost non-green power electricity products. About a dozen Illinois CCAs discontinued their green power products from 2016 to 2017. This ongoing trend is primarily attributable to changes in the cost-competitiveness of Illinois CCAs. In 2011, relatively high basic service rates (the rates offered by the state's investor-owned utilities) allowed CCAs to offer cost savings as high as $\$ 0.03 / \mathrm{kWh}$ (LEAN 2018). Many CCAs used their cost advantages to integrate green power into their electricity portfolios. However, from 2012 to 2014, falling basic service rates eroded the CCA cost advantage and drove many CCAs to discontinue their green power products (Figure 25). Basic service rates have risen since 2014, but CCA green power sales have not rebounded.

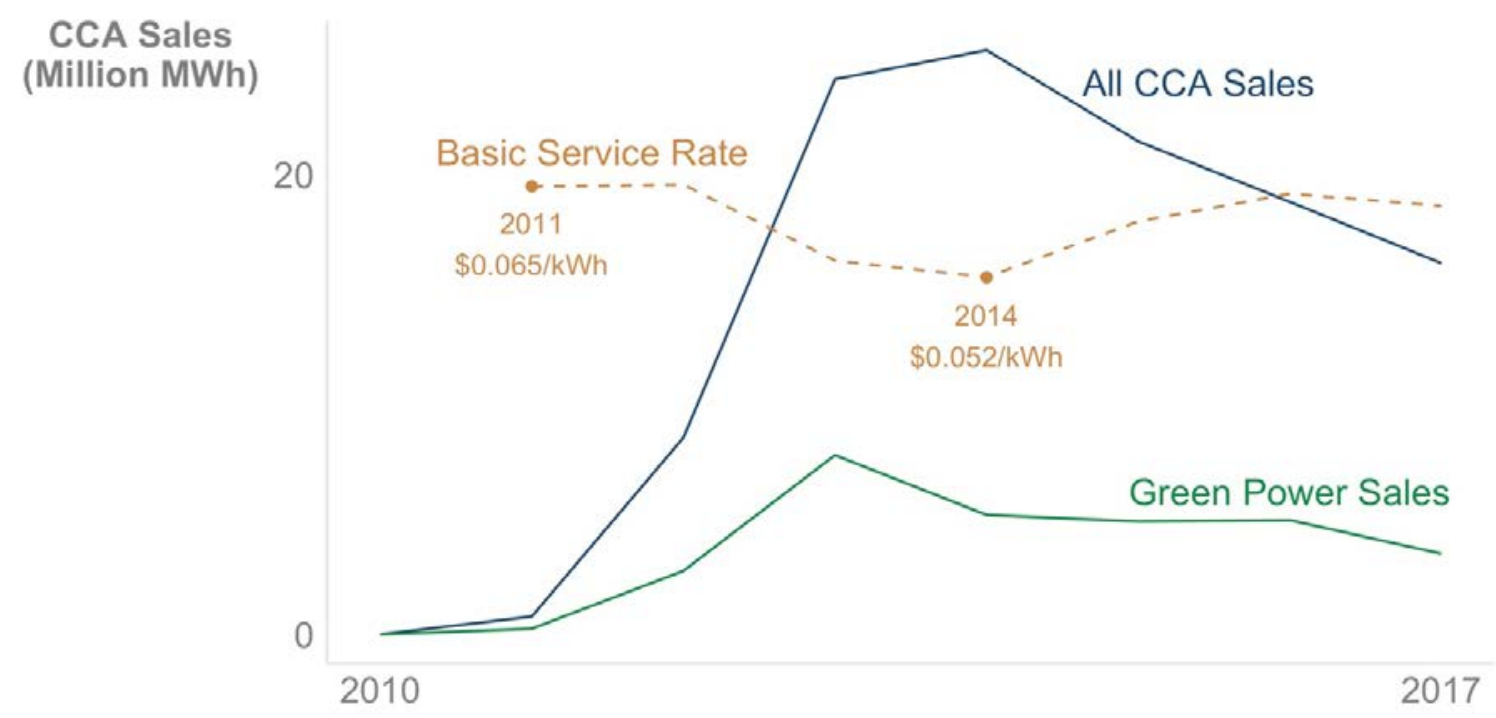

Figure 25. Illinois CCA sales and basic service rates, 2010-2017

${ }^{9}$ Some CCAs outside California have also used joint powers agreements, but their use outside is less prevalent in other states. 


\section{Massachusetts}

The Massachusetts CCA landscape comprises dozens of individual municipality programs as well as the Cape Light Compact program, which aggregates on behalf of 21 municipalities in the Cape Cod region. Before 2017, customers of the Cape Light Compact had the option to opt in to a $100 \%$ renewable energy product. Similar to utility green pricing programs, participation in the opt-in program was relatively low and resulted in low green powers sales. In 2017, Cape Light Compact switched their service so that customers are automatically enrolled into a $100 \%$ renewable energy product. The result illustrates the significant impacts of CCAs with opt-out green power products: Cape Light Compact's green power sales increased from about 4,700 MWh in 2016 to about 880,000 MWh in 2017. Cape Light Compact's decision to switch to an opt-out structure drove a 170\% increase in Massachusetts' CCA green power sales overall, although green power sales outside Cape Light Compact remained relatively stable.

In addition to switching to opt out, Cape Light Compact implemented a new structure to keep costs low in the near term while promoting local renewable energy in the long term. Partnering with its supplier, NextEra, Cape Light Compact provides green power consisting of $1 \%$ local renewables and $99 \%$ nationally sourced unbundled RECs. NextEra places the premium paid on the unbundled RECs into a Renewable Energy Trust overseen by an independent trustee (NextEra 2018). The use of nationally rather than regionally sourced RECs keeps program costs low. At the same time, NextEra can later use proceeds from the Trust to finance regional renewable energy projects (Lichtenstein and Reid-Shaw 2017).

\section{New York}

Westchester Power-New York's only active CCA in 2017-serves about 96,000 customers in Westchester County (Westchester Power 2018). In its first full year of operation, Westchester Power sold about 356,000 MWh of green power to 64,000 customers (Westchester Power 2018). As of December 2017, 56 other communities in New York had passed local laws to begin the CCA implementation process (Binns 2018). By January 2018, the New York State Public Service Commission had approved CCAs in the City of Elmira; the towns of Oneonta, Mountour, Horseheads, Union, and Binghamton; and the Village of Mountour Falls (NY PSC 2018).

\section{Ohio}

In Ohio, CCA green power sales increased by about $12 \%$ from 2016 to 2017, largely due to an increase in sales in the City of Cincinnati's program. Over 100 CCAs are active in Ohio, but to our knowledge, only Cincinnati and Cleveland have offered green power. The absence of green power from Ohio CCAs may reflect the difficulty of offering green power in markets with lower electricity costs. Of the seven states that have passed enabling legislation, Ohio has the lowest residential electricity rates (EIA 2016). In states with low electricity costs, CCAs may find it more difficult to justify paying green power premiums, especially if those premiums offset any cost savings achieved through aggregation. 


\section{Power Purchase Agreements}

In a power purchase agreement (PPA), an electricity customer enters into a long-term contract with a generator to buy electricity. PPAs may be signed for on- or off-site systems. PPAs for residential on-site systems generally do not convey RECs to the end-use customers and therefore do not qualify as green power. Data for on-site nonresidential systems are relatively scarce, but these systems represent a small fraction of nonresidential PPAs (EPA 2017). For these reasons, our analysis in this section is limited to off-site PPAs where RECs are conveyed to nonresidential customers (Figure 26).

PPAs have two primary forms. In a physical PPA, the customer enters into a contract to buy electricity at a negotiated PPA rate. The purchased electricity is credited toward the customer's electric demand such that, from a billing perspective, the customer uses the electricity (regardless of whether the electricity is physically delivered to the customer's site). In a financial PPA, the customer enters into a contract for differences for electricity at a negotiated PPA rate.

The generator sells electricity into the local grid at the local wholesale rate. The customer and generator are financially obligated to settle differences between the PPA rate and the wholesale rate; the customer pays the generator the difference when the wholesale rate is less than the PPA rate, and the generator pays the customer the difference when the wholesale rate is greater than the PPA rate. The financial PPA structure allows both the customer and the generator to hedge against wholesale market price volatility.

PPA sales and participation estimates in this report are based on data from BNEF (2018) and S\&P Global Market Intelligence (2018).

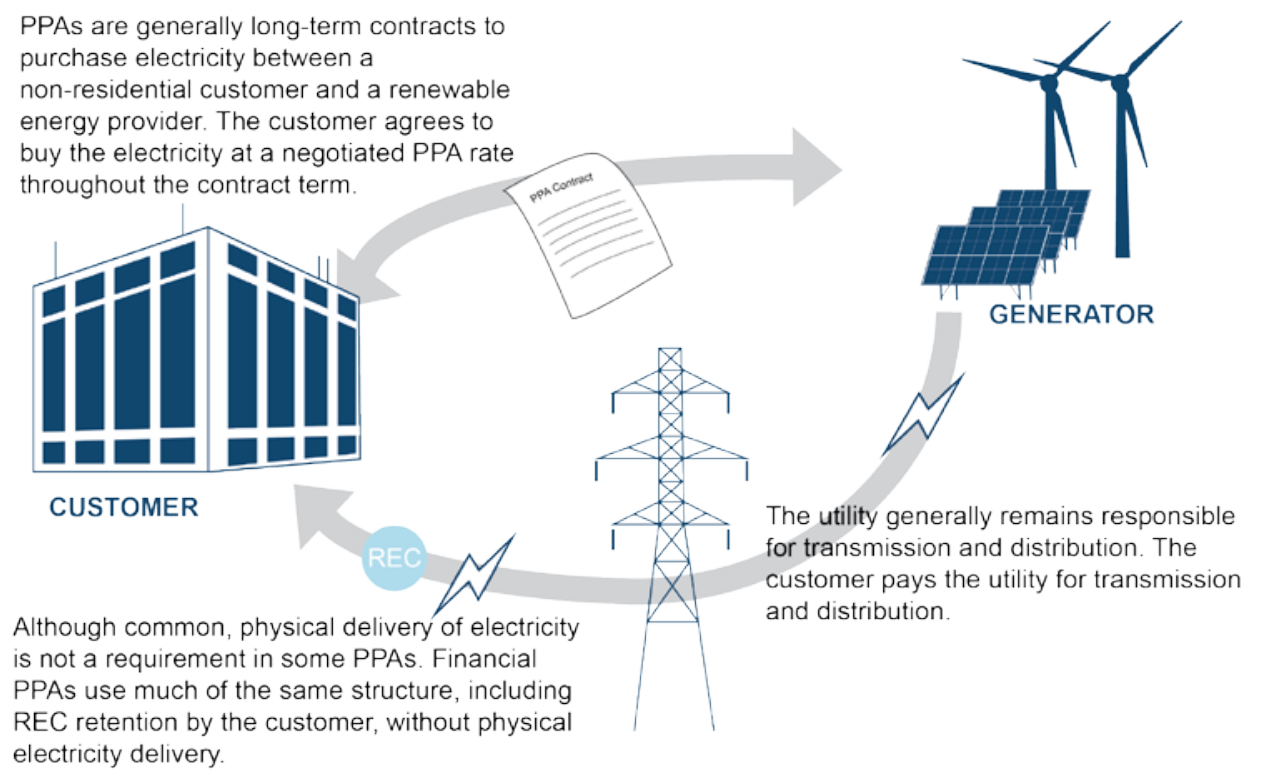

Figure 26. How power purchase agreements work

The figure provides a simplified schematic for visualization purposes. Specific contract structures may vary. 


\subsection{Status of PPAs}

In 2017, 21.3 million MWh of green power were consumed through 273 PPAs; these results reflect projects commissioned by the end of 2017 where we estimate that the customer purchases the RECs for voluntary purposes (Figure 27). The large increase in sales from 2016 to 2017 is the result of projects signed in 2015 being commissioned. Though not shown in Figure 27, sales as of July 2018 have not grown much from end of year 2017 because projects signed in 2018 have for the most part yet to come online.

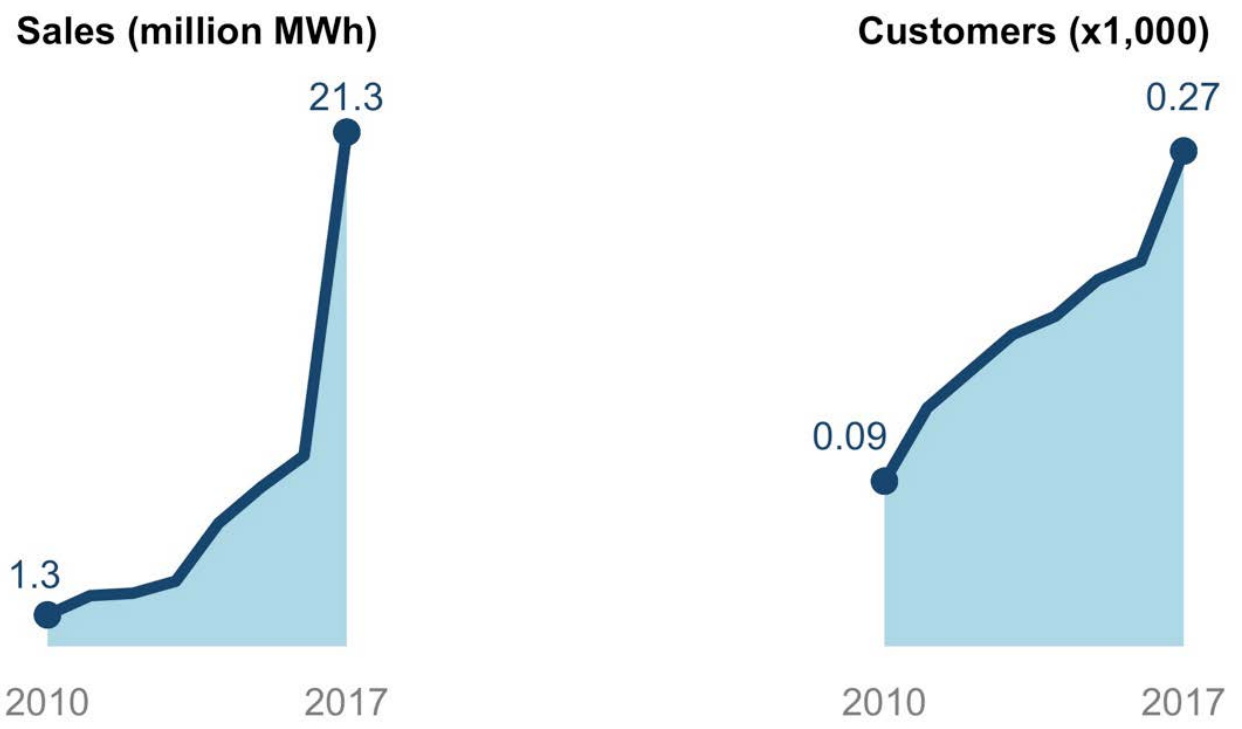

Figure 27. PPA sales and participation, 2010-2017

\subsection{Trends in PPAs}

While the data presented in Figure 27 reflect only PPAs where the customer owns the RECs, the remainder of this section presents trends in PPAs generally, regardless of whether the RECs are retained by the PPA signer.

PPA project implementation can take months or years between contract signing and project commissioning. As a result, some PPAs that are signed in one year may not actually begin to generate electricity until the following year or even later. In $2015,3,683 \mathrm{MW}$ of project capacity was contracted for through CCAs, but 2,779 MW of that capacity remained uncommissioned by the end of 2016. In 2017 and 2018, about 2,364 MW of the 2015 contracts came online, which is the primary driver of the significant increase in PPA sales from 2016 to 2017 (Figure 28). These projects contribute to the vast majority of the increase from 2016 PPA sales to 2017 PPA sales, though projects signed in 2016 are also a contributor: as of July 2017, only 501 MW of projects signed in 2016 were commissioned, compared to 1,037 MW as of July 2018. 


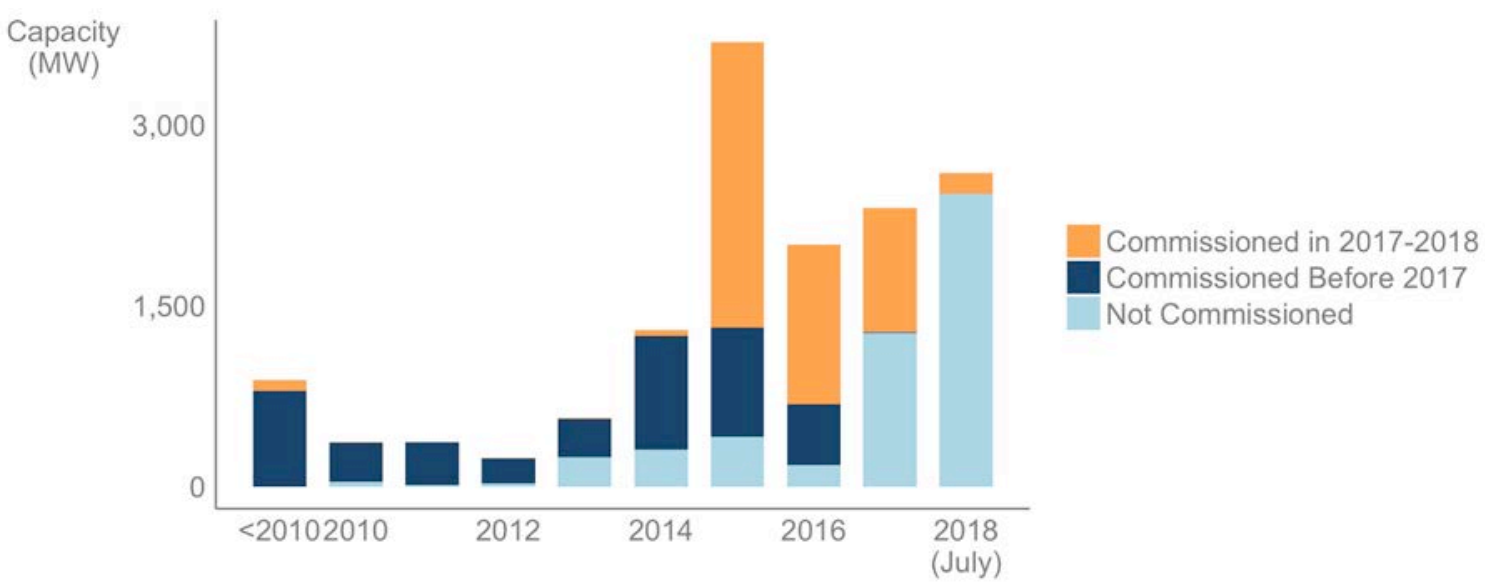

Figure 28. Project capacity and commissioning status by year

The height of the bars represents capacity contracted for in a given year, while the colors represent whether those contracts have been commissioned (i.e., projects have begun producing electricity) and in which year.

In 2017, the tech sector contracted for the largest amount of MW via PPAs (Figure 29). The tech sector has not rebounded to 2015 levels but was showing a large increase into the first part of 2018, with nearly 1,400 MW signed as of July 2018. Manufacturers also signed large deals in 2017, due to signings by Kimberly-Clark (245 MW in two transactions) and General Mills (100 MW).

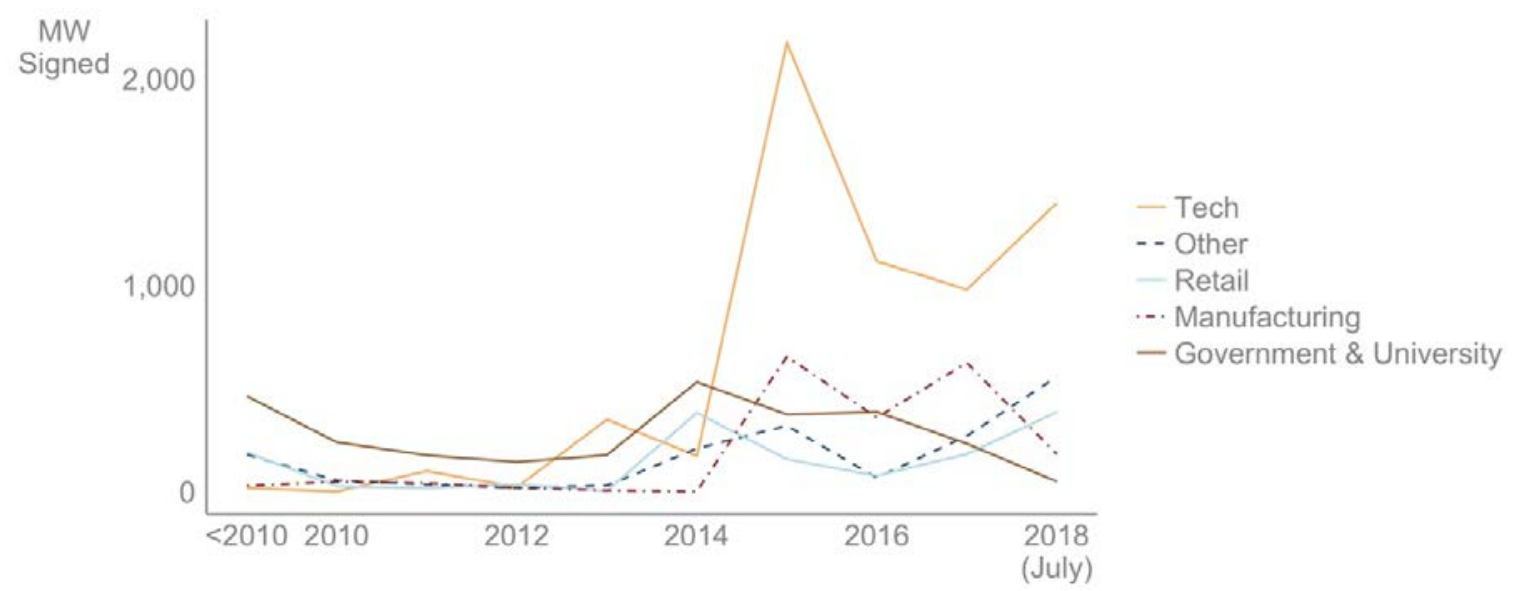

Figure 29. PPA MW signed by sector, through July 2018

The largest purchasers cumulatively through July 2018 were mostly the same as in previous years, with the additions of AT\&T, General Motors, and Target to the top 15 list (Figure 30). AT\&T signed $820 \mathrm{MW}$ in 2018 from wind facilities in Texas and Oklahoma; General Motors signed $200 \mathrm{MW}$ in 2017 from wind in Illinois and Ohio, and Target signed $100 \mathrm{MW}$ in 2017 from wind in Kansas. 


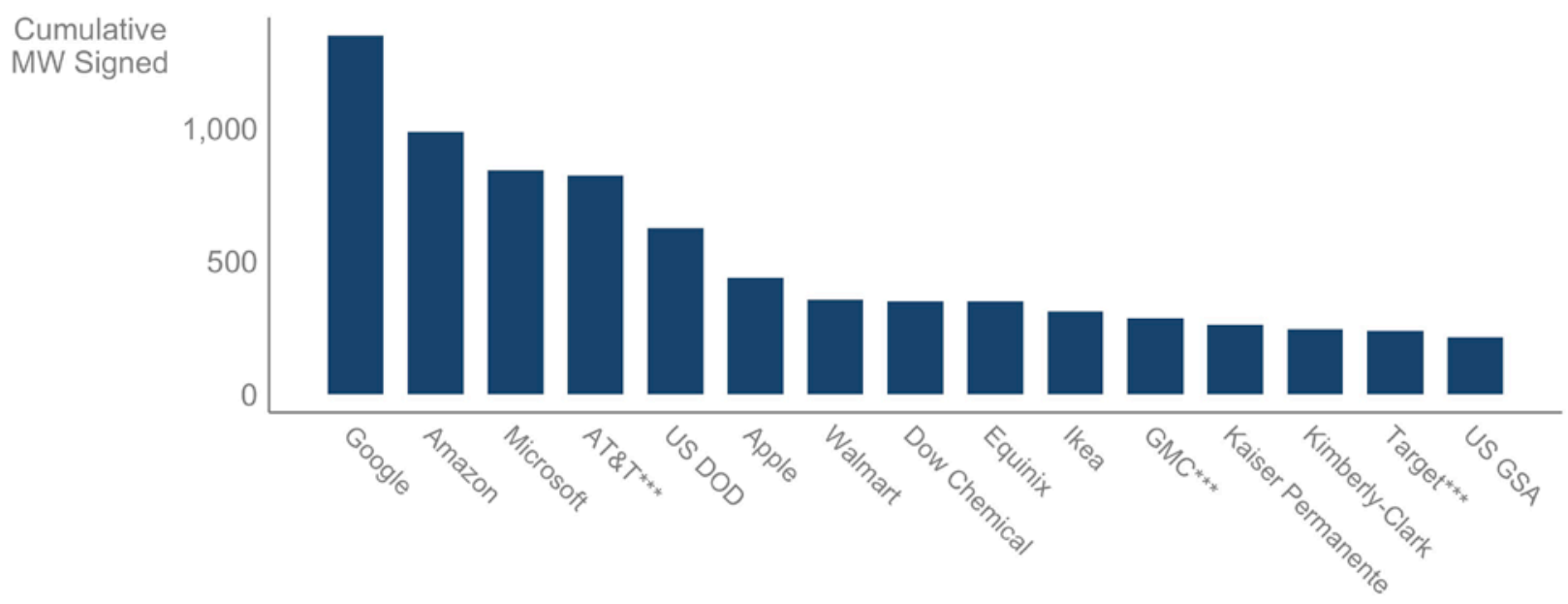

Figure 30. Leading institutions signing PPAs, through July 2018

*** Company new to the top 15 in 2017

US DOD = U.S. Department of Defense; US GAS = U.S. General Services Administration

Wind resources continue to dominate the PPA market (Figure 31), maintaining 60\%-70\% share in recent years. Solar resources are the second most common but have not increased annually as quickly as wind resources. Only minimal amounts of biomass and waste resources are being contracted via PPAs.

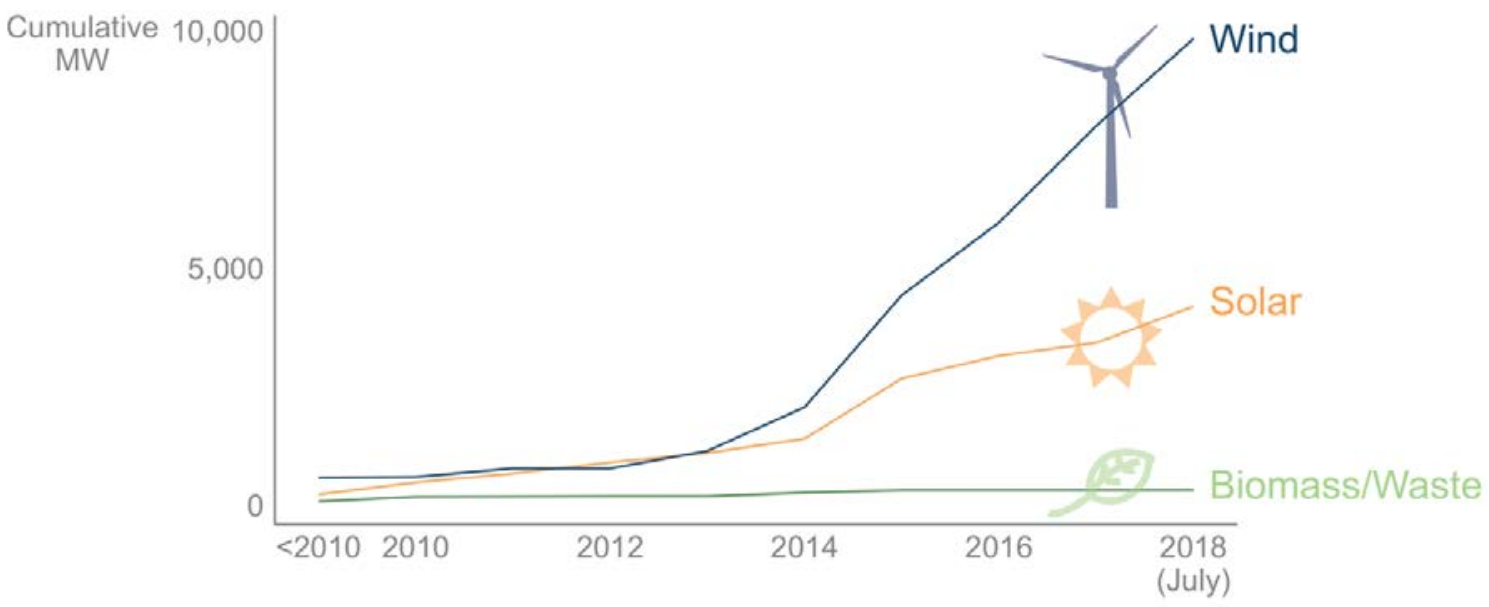

Figure 31. Cumulative MW of PPA renewable resources, through July 2018 
The PPA market has seen some examples of buyer aggregation, though that structure is not yet commonplace. Buyer aggregation involves multiple purchasers signing PPAs with the same generator or generators. Buyer aggregation could reduce transaction costs, which pose barriers to financial PPAs for many small buyers (Heeter, Cook, and Bird 2017). These structures vary but typically involve at least one large buyer paired with additional medium to smaller sized buyers. In 2016, the Massachusetts Institute of Technology (MIT), Boston Medical Center, and the Post Office Square Redevelopment Corporation signed a 25-year PPA for 60 MW of solar. MIT's share was the largest, at $44 \mathrm{MW}$, while Boston Medical Center's share was $16 \mathrm{MW}$, and Post Office Square Redevelopment Corporation signed for less than 1 MW (Heeter, Cook, and Bird 2017). More recently, Akamai, Etsy, and Swiss Re partnered in 2018 to buy 290 MW of renewable energy (125 MW of wind in Illinois and 165 MW from solar in Virginia). 


\section{Community Solar}

In a community solar program, a utility or third-party project developer develops a solar project and sells the output to multiple subscribers (Figure 32). Community solar subscribers are generally compensated through utility bill credits that are proportional to the size of their subscription.

To date, most community solar customers have not received the RECs associated with their energy subscriptions. Community solar output is often used by utilities to meet RPS compliance obligations. For this reason, most community solar sales do not meet our definition of green power. ${ }^{10}$ In Section 9.1, we distinguish green power community sales data from sales representing the broader community solar market. In Section 9.2, we provide data on the community solar market as a whole, including data for sales that do not qualify as green power. In Section 9.2.2, we identify and summarize four innovative programs that are retiring RECs on behalf of subscribers and therefore do meet our definition of green power.

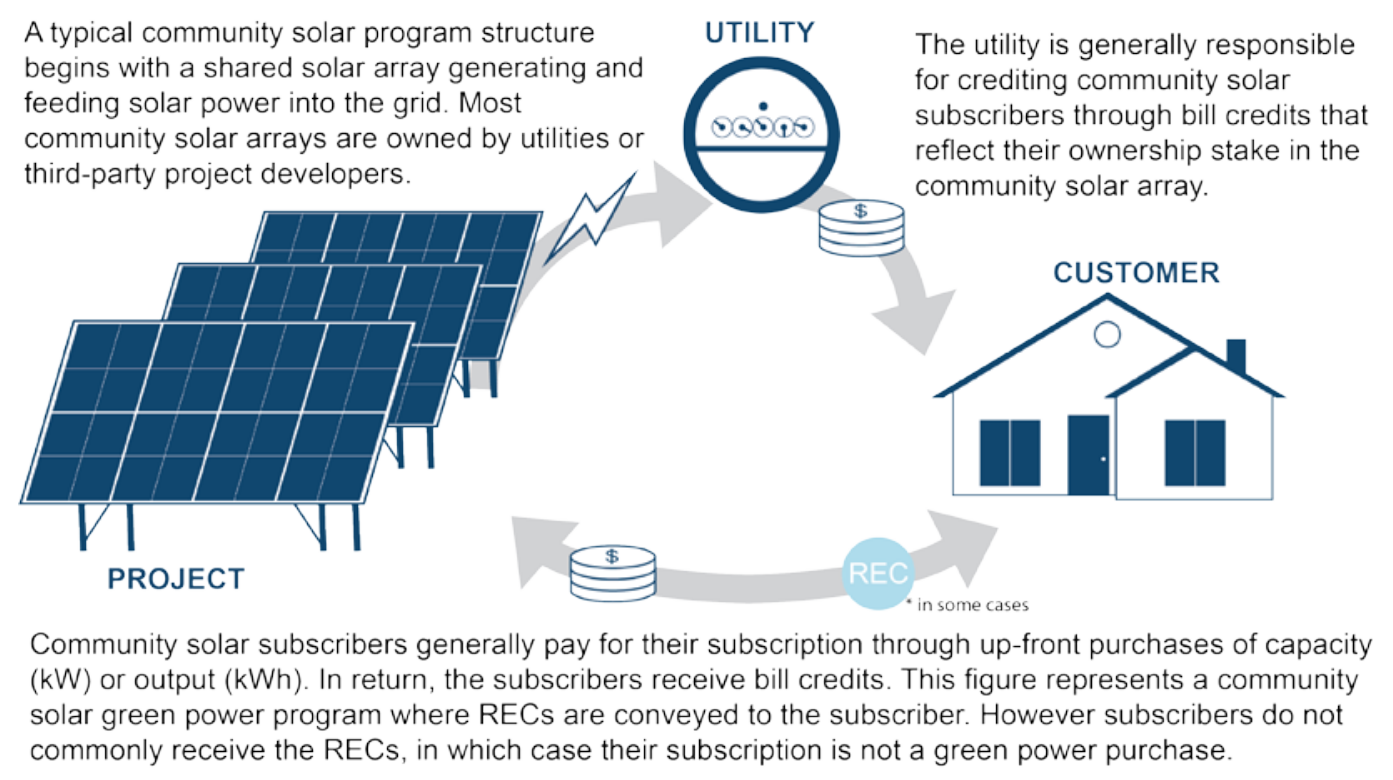

Figure 32. How community solar works

The figure provides a simplified schematic for visualization purposes. Specific program structures vary.

\subsection{Status of Community Solar}

In 2017, about 67,000 customers bought around 800,000 MWh of community solar output (Figure 33) in the United States. We estimate that a small fraction of these sales qualifies as green power: about 4,700 customers procured about 80,400 MWh of green power through four projects (see Section 9.2.2).

\footnotetext{
${ }^{10}$ It is important to note that most residential rooftop PV sales similarly do not meet our definition of green power, because PV system owners or PPA customers commonly give up RECs to participate in utility incentive programs.
} 

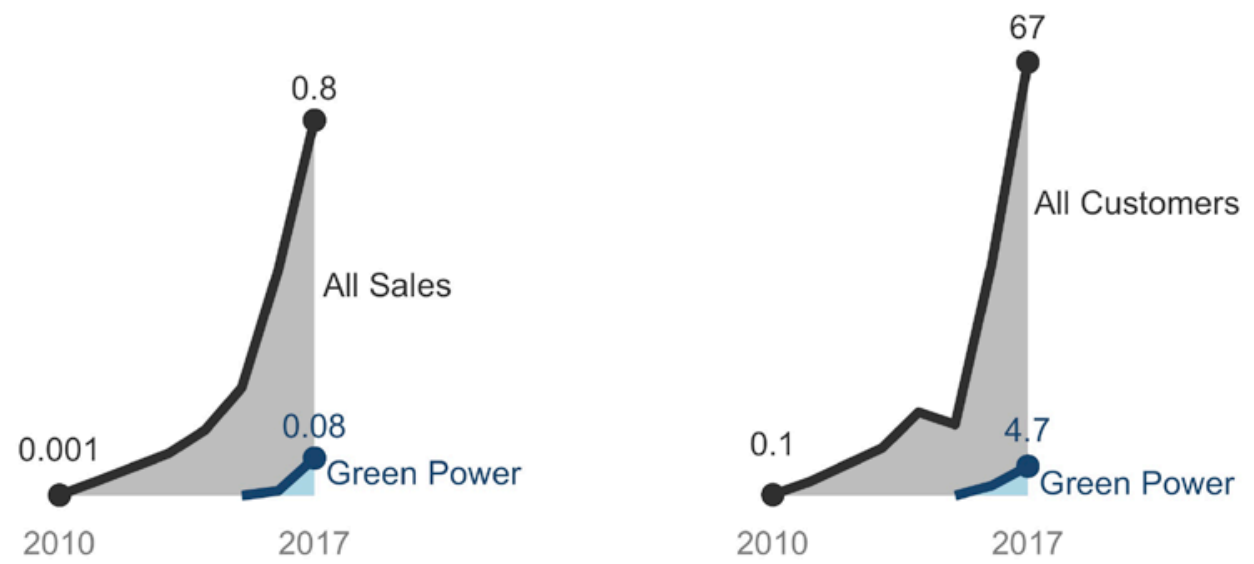

Figure 33. Community solar sales and participation, 2010-2017

\subsection{Trends in Community Solar}

Community solar continues to exhibit remarkable growth, reaching about $720 \mathrm{MW}$ of installed capacity by the end of 2017, with about $387 \mathrm{MW}$ installed in 2017 alone (Chwastyk et al. 2018), including projects that do not qualify as green power. By one projection, more than 2,000 MW could be installed between 2017 and 2021 (Honeyman, Shiao, and Krulewitz 2017). Community solar projects were active in 40 states by the end of 2017 (Figure 34). ${ }^{11}$

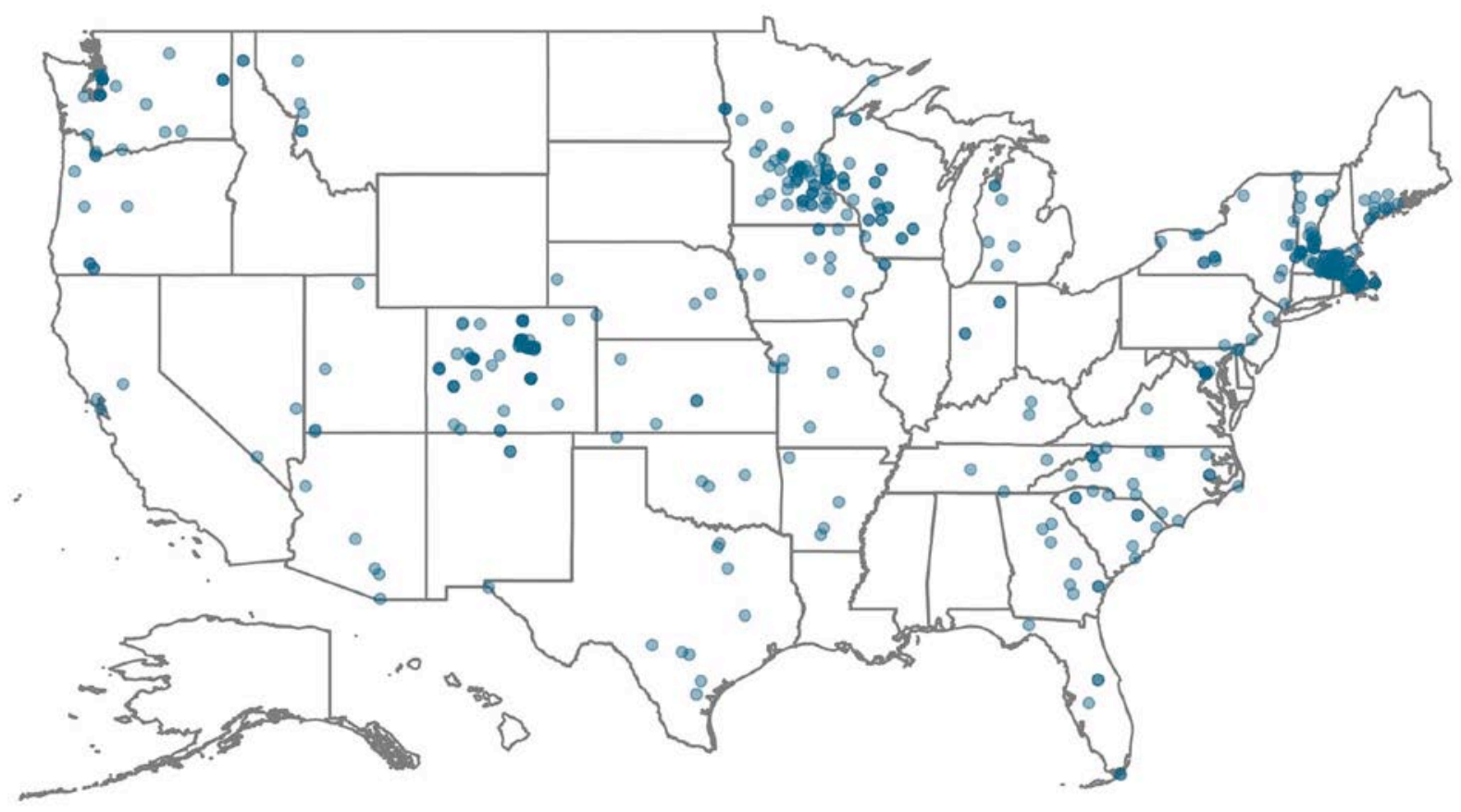

Figure 34. Active community solar projects as of end of 2017

\footnotetext{
${ }^{11}$ A publicly available version of the community solar project list is available at https://data.nrel.gov/submissions/95 (“Community Solar Project Database,” NREL).
} 


\subsubsection{The Effects of Community Solar Programs}

About $70 \%$ of community solar projects operate in states with programs to support community solar, such as virtual net metering or group billing. Virtual net metering allows net metering credits to accrue from off-site systems to remotely located customers. These programs increase customer incentives to adopt community solar and may facilitate customer acquisition.

Nonetheless, roughly $30 \%$ of community solar projects operate in states without such programs. Similarly, the majority of future community solar capacity is expected to be deployed in six states with community solar programs: California, Colorado, Maryland, Massachusetts, Minnesota, and New York (Figure 35), based on projections from Honeyman, Shiao, and Krulewitz (2017). In this section, we briefly explore these community solar programs and how they continue to drive the community solar market.

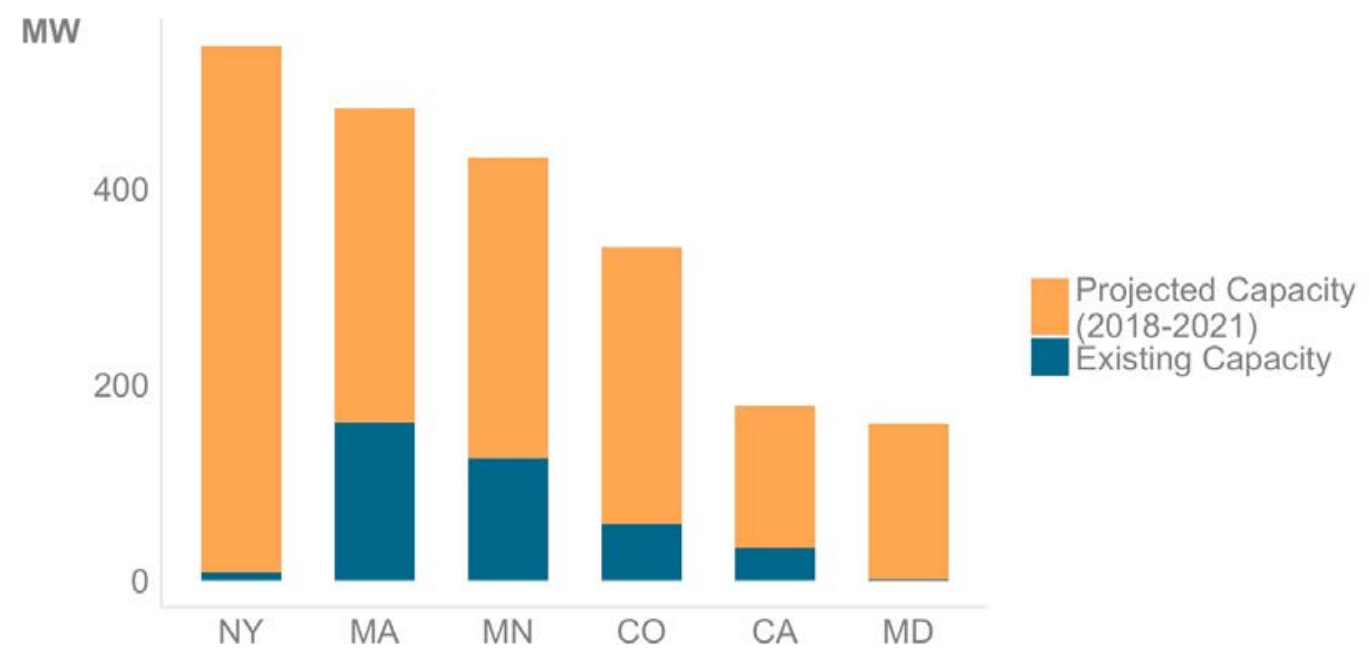

Figure 35. Current and projected community solar capacity in six leading states

Data sources: Honeyman, Shiao, and Krulewitz 2017; O'Shaughnessy et al. 2018

\section{New York}

In 2015, as part of the state's Reforming the Energy Vision program, the New York Public Service Commission implemented a community distributed generation program that allows virtual net metering. Community solar projects are also eligible for financial incentives through the state's NY-Sun program. As a result of these programs, New York is projected to deploy more community solar than any other state in the coming years: Honeyman, Shiao, and Krulewitz (2017) project that more than $500 \mathrm{MW}$ of capacity could be deployed in New York alone from 2018 to 2021 . As of July 2018, 18 community solar projects were completed and an additional 312 projects were in the pipeline (NYSERDA 2018).

\section{Massachusetts}

The Massachusetts community solar market is driven by the state's virtual net metering program as well as a historically strong SREC market. In early 2017, community solar accounted for about one-third of the SREC queue (Honeyman, Shiao, and Krulewitz 2017). Beginning in 2018, Massachusetts transitioned from its existing SREC program to a new Solar Massachusetts Renewable Target (SMART) program. Subscriber compensation is projected to be lower under 
the SMART program, however several developers state that the new program provides enough certainty to support further market growth (Trabish 2017).

\section{Minnesota}

Minnesota's community solar market is supported by state-level legislation and financial incentives offered by Xcel Energy, the state's largest utility. These measures were, at first, largely ineffective at enabling projects to come online, due to various regulatory delays, but the Minnesota community solar market finally rose in 2017, with more than 50 projects being implemented (Hannah 2017). Beginning in 2018, all new community solar projects are required to compensate subscribers according to a value of solar tariff rather than the traditional retail rate (Gleckner 2016). The switch to the value of solar tariff — which is lower than the retail rate - has slowed the Minnesota community solar market. The project pipeline shrunk from a peak of over 1,400 MW in late 2015 to under $600 \mathrm{MW}$ in late 2017 (Hannah 2017). Most of the projected Minnesota market in Figure 35 represents projects in the pipeline that were grandfathered into the previous retail rate compensation method. Honeyman, Shiao, and Krulewitz (2017) project a weaker Minnesota community solar market beyond 2019 as developers adjust to the value of solar tariff.

\section{Colorado}

Colorado's community solar market is supported by the state's Solar Gardens program and the associated financial incentives offered by Xcel Energy, the state's largest utility. The financial incentives provided by Xcel Energy's Solar*Rewards Community program have allowed community solar developers to offer attractive rates to subscribers. In return, Xcel Energy owns the RECs and uses them toward RPS compliance, which is similar to other state community solar programs. The Solar*Rewards Community program is projected to support more than $100 \mathrm{MW}$ of community solar deployment from 2017 to 2019 (Honeyman, Shiao, and Krulewitz 2017).

\section{California}

California's community solar market is driven by state legislation requiring the state's investorowned utilities to procure up to $600 \mathrm{MW}$ of community solar by 2019 . The California program is unique in that the utilities are required to retire RECs on behalf of subscribers, though only one investor-owned utility (PG\&E) has implemented this design to date, to our knowledge. This requirement also poses a challenge in providing customer cost savings given that the value of RECs cannot be used to reduce subscription rates. California community solar subscribers also bear other charges, such as exit fees, ${ }^{12}$ that undermine the economics of community solar subscriptions (Trabish 2017). While customers in other major state markets generally save money by subscribing to community solar, California community solar customers pay a premium over standard utility rates (Honeyman, Shiao, and Krulewitz 2017). Due primarily to this challenge, Honeyman, Shiao, and Krulewitz (2017) project that the investor-owned utilities will fall well short of the 2019 target of $600 \mathrm{MW}$.

\footnotetext{
${ }^{12}$ In regulated electricity markets, utilities make long-term investments on behalf of retail electricity customers. When customers "exit" utility service (e.g., to join community solar), the utilities continue to bear these long-term costs but now have fewer customers from which to recoup the costs. To avoid inter-customer cost shifting, exit fees are levied to compensate investor-owned utilities for sunk investments made on behalf of existing customers.
} 


\section{Maryland}

In 2015, Maryland passed legislation calling for a 193-MW community solar pilot program. Honeyman, Shiao, and Krulewitz (2017) project that Maryland will deploy 159 MW of this target between 2017 and 2021. The projected shortfall is due to relatively low SREC prices, which fell in 2016 as PV output began to exceed requirements to meet the state RPS. Maryland subsequently increased RPS targets in 2017, which could eventually increase SREC prices and support community solar development. The first community solar project under the Maryland pilot was interconnected in March 2018.

\subsubsection{Community Solar Green Power Products}

Most community solar projects to date do not qualify as green power programs given that subscribers do not own the RECs. Community solar programs could be restructured as green power programs in at least four ways (Table 8). The most straightforward model is to retire the project RECs on behalf of the subscribers. Alternatively, community solar program administrators could allow customers to choose whether to purchase the RECs, whether through an opt-out or opt-in model. In some cases, the value of the community solar RECs may be too high to justify retiring the RECs on behalf of subscribers, especially in states with active SREC markets. In these cases, community solar program administrators could sell the community solar RECs but buy lower-cost "replacement" RECs to retire on behalf of their subscribers. The replacement REC model would allow community solar subscribers to make a green power claim, even if that claim is not based on local solar.

Table 8. Potential Community Solar Green Power Models

\begin{tabular}{ll}
\hline Model & Description \\
\hline Community solar green power & $\begin{array}{l}\text { Community-solar generated RECs are retired on behalf of } \\
\text { subscribers. }\end{array}$ \\
Opt-out community solar green power & $\begin{array}{l}\text { Community-solar generated RECs are retired on behalf of } \\
\text { subscribers by default, but subscribers have the option to } \\
\text { sell their RECs to obtain a lower rate. }\end{array}$ \\
Copt-in community solar green power & $\begin{array}{l}\text { Subscribers do not own the RECs by default but have the } \\
\text { option to opt-in to a higher rate with the associated RECs. }\end{array}$ \\
\hline
\end{tabular}

To our knowledge, only four community solar green power programs are active:

- MCE (formerly Marin Clean Energy) is a CCA serving Marin County, Napa County, unincorporated Contra Costa County, and other cities in the region. MCE offers CCA customers the opportunity to subscribe to shares from a 1-MW community solar facility in Novato, CA. MCE (2018) estimates that in 2017, about 160 CCA customers bought about $600 \mathrm{MWh}$ of green power through the Local Sol program. 
- Pacific Gas \& Electric (PG\&E) began offering the Solar Choice community solar product in 2016. Solar Choice subscribers may choose to purchase the equivalent of $50 \%$ or $100 \%$ of their annual energy use. PG\&E uses program revenues to deploy community solar projects in its service territory as needed to match demand. Under state legislation, PG\&E and all other California investor-owned utilities are required to retire RECs on behalf of the subscribers. The PG\&E Solar Choice program sold about 34,000 MWh of green power in 2017 (PG\&E 2018).

- Rocky Mountain Power's (RMP's) Subscriber Solar product allows customers to subscribe to shares of a 20-MW community solar project near Holden, Utah. Subscribers sign on for up to a 20-year term with a fixed solar rate. The program was fully subscribed as of the end of 2017, and RMP is looking for potential sites to expand the program. RMP voluntarily retires all RECs on behalf of subscribers. The Subscriber Solar program sold about 43,000 MWh of green power in $2017 .{ }^{13}$

- The Sacramento Municipal Utility District (SMUD) has offered community solar through the SolarShares program since 2008. Like other community solar programs, SMUD initially used the SolarShares RECs for RPS compliance purposes and passed the value of the RECs through to subscribers as a cost savings measure. In 2017, SMUD amended the SolarShares program so that all RECs are retired on behalf of subscribers. The SolarShares program sold about 25,000 MWh of green power in 2017. For more information about the program, see Text Box 1 (page 41).

An unknown number of community solar programs allow customers to opt in to buy their RECs. For instance, the Revision Energy Community Solar Farm in Maine sells RECs to improve project economics but allows interested customers to buy back their portion of RECs (Revision Energy 2018). Our community solar estimates do not include green power sales through opt-in models such as Revision Energy's. Assuming customer participation rates in opt-in community solar REC purchases are similar to participation rates in other opt-in programs (e.g., utility green pricing), green power sales through such opt-in programs are likely small relative to sales through the four community solar programs described above.

\footnotetext{
${ }^{13}$ Utah has a voluntary renewable energy goal rather than a binding RPS. The renewable energy goal is not factored out of the green power sales estimate.
} 


\section{Expanding Electricity Product Choice: Opportunities and Challenges for Green Power Markets}

U.S. retail electricity customers have access to more electricity choices than ever. The proliferation of electricity product choice is mostly a positive development for green power markets and for customers seeking green power. The expansion of electricity product offerings has contributed to recent growth in the voluntary green power market. PPAs and CCAs alone have added around 30 million MWh of green power sales per year. However, the expansion of electricity products also poses challenges to green power markets. New products may generate customer confusion that could, in some cases, reduce green power demand. In this section, we summarize how the expansion of electricity product choices creates opportunities and challenges for green power markets. We limit our discussion to five products: utility basic service, ${ }^{14}$ utility green pricing, competitive suppliers, CCAs, and community solar. And, the focus of this section is on residential and small commercial customers, which are arguably less informed about electricity products and more susceptible to confusion during product choice. We exclude utility renewable contracts, unbundled RECs, and PPAs because these products are generally used by large sophisticated green power buyers that are arguably less susceptible to product confusion.

For the purposes of this section, we categorize retail electricity products into two subtypes. Default power products refer to products that offer an electricity portfolio that complies with but does not significantly exceed an RPS. Green power products refer to the products summarized in this report where RECs are retired on behalf of customers in excess of RPS. Most retail electricity products include variants of both types. For instance, some competitive suppliers offer green power while others offer default power. Most utility basic service represents default power, however this may change as utilities begin to voluntarily procure renewable energy in excess of state RPS (see Section 10.1).

Demand for green power increases whenever customers switch from a default to a green power product. The expansion of retail electricity products may increase demand for green power by increasing the number of pathways for default-to-green power switching. Figure 36 illustrates this concept. Each connecting line represents a default-to-green power switch that would increase demand for green power. The number of pathways increase as retail electricity product choice increases. In recent years, customer switches from basic utility service to CCAs have been the most impactful in terms of effects on green power demand. Some community solar programs have begun retiring RECs on behalf of subscribers (see Section 9.2.2), opening up switches to community solar as a default-to-green power pathway.

\footnotetext{
${ }^{14}$ Utility basic service refers to the default electricity package offered to utility customers.
} 


\section{PATHWAYS THAT INCREASE GREEN POWER DEMAND}

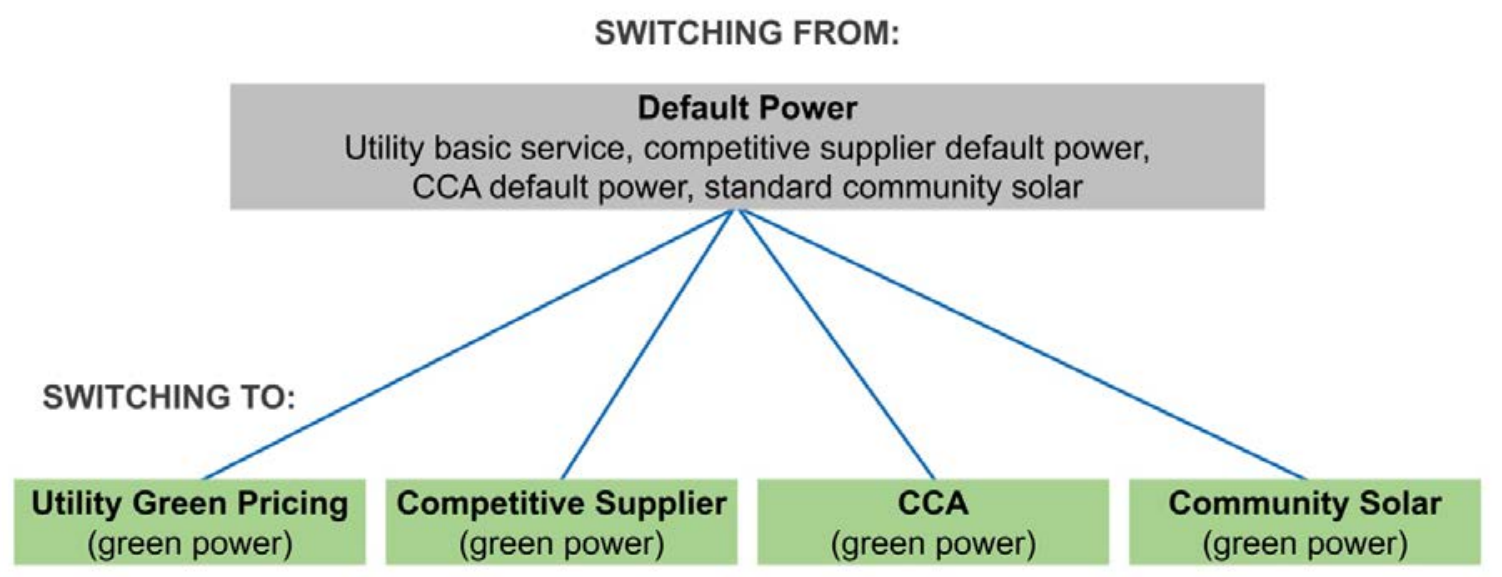

Figure 36. Customer product switching pathways that increase green power demand

Demand for green power decreases whenever a customer switches from a green power to a default power product. Figure 37 illustrates the pathways for green-to-default power switching. The expansion of retail electricity product choice increases the number of ways that customers can switch from green to default power.

\section{PATHWAYS THAT REDUCE GREEN POWER DEMAND}

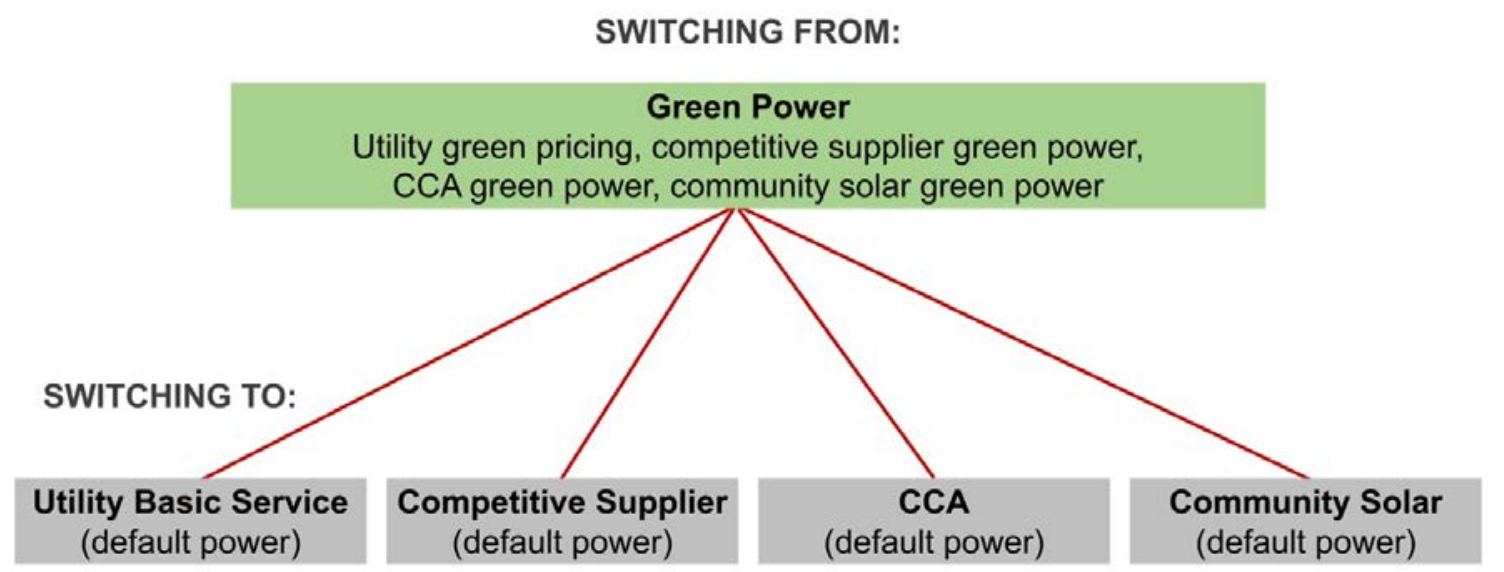

Figure 37. Customer product switching pathways that decrease green power demand 
Retail electricity customers are generally unaware of their renewable energy options (Rogers 2011) and may not fully understand the implications of switching between products that do and do not back their electricity use with RECs. Given limited customer awareness, the expansion of green power product offerings could result in customer confusion. To illustrate, suppose a customer procures green power through a utility green pricing program. Then suppose the customer subscribes to a new community solar project serving her area. The customer may assume the community solar project provides a similar green power product as utility green pricing and may choose to discontinue her participation in utility green pricing. However, if the community solar developer does not retire RECs on behalf of the customers - consistent with most community solar projects - the customer no longer has a legal claim to be using green power.

The community solar example illustrates that potentially misleading product perceptions may affect customer choices. The perceptions may be misleading in the sense that most sales through most electricity products represent default rather than green power, particularly for community solar and competitive suppliers (Figure 38). Products that are perceived to offer green power may draw customers away from green power products like utility green pricing (see case study in Text Box 1).

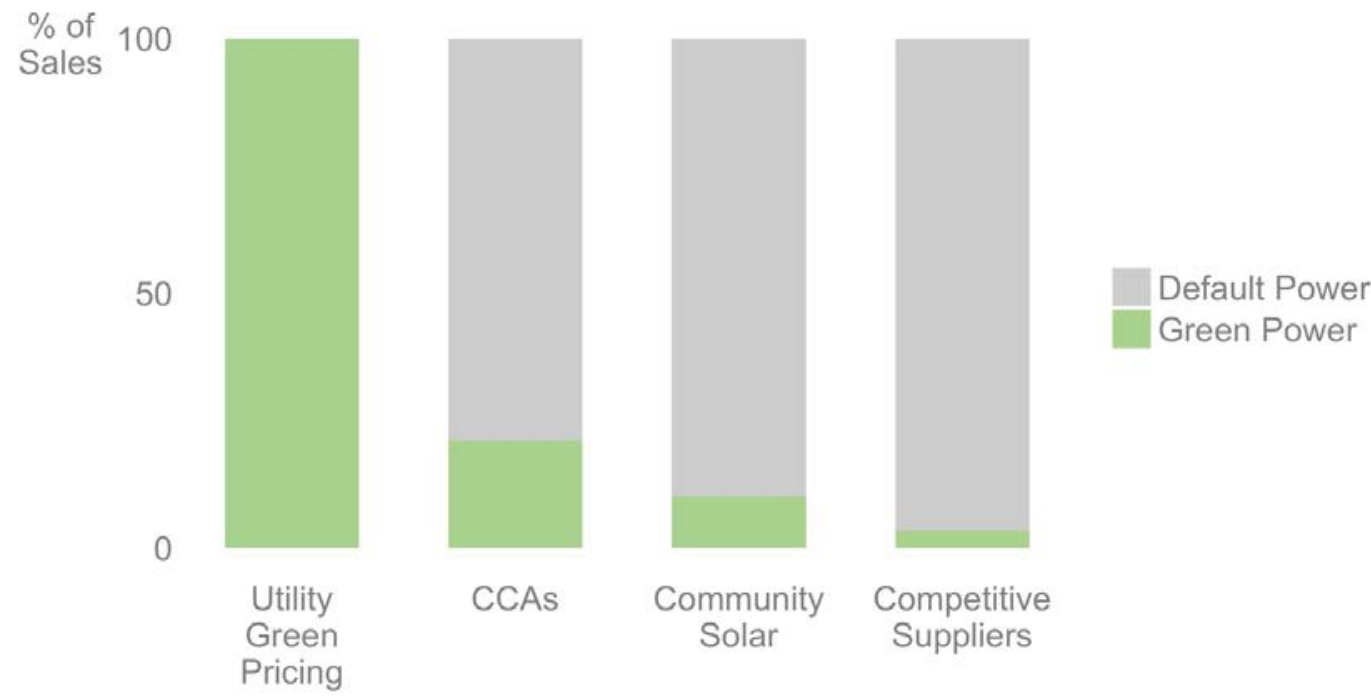

Figure 38. Green power share of total sales by electricity product

To date, the expansion of retail electricity products has increased green power demand, particularly through default-to-green power shifts in CCAs. There is no evidence that the expansion of new green power products has reduced green power demand at any significant scale. However, most CCAs and community solar programs do not offer green power, increasing the risk of inadvertent green-to-default power switching. There are at least two ways to mitigate the potentially adverse effects of customer confusion on green power markets. First, regulators and utilities could increase product transparency through informational resources. For instance, Xcel Energy clearly states that community solar subscribers cannot claim to use solar energy (Xcel Energy 2017). Similarly, the Minnesota Commerce Department advises subscribers to study whether their community solar contract includes RECs, which they state represent the "legal rights to the environmental benefits" of solar energy (MN 2018). Second, more electricity 
products could be designed to offer green power by default (see example in Text Box 1), or at least provide customers the option to procure green power. We discuss several ways that community solar programs could offer green power in Section 9.2.2.

\section{Text Box 1. The SMUD SolarShares Program: A Case Study of the Opportunities and Challenges of Expanding Electricity Product Choice}

The SMUD SolarShares program provides an illustrative case study of the potential opportunities and challenges of expanding product choice. Since 2007, SMUD has offered community solar to residential customers through the program. Under the initial SolarShares structure, SMUD used the community solar RECs for RPS compliance. SMUD also administers Greenergy, one of the largest utility green pricing programs in the country.

After expanding SolarShares to large commercial customers, SMUD saw that some large commercial Greenergy customers were also interested in SolarShares. Indeed, many customers participated in both programs. One concern was that some Greenergy customers saw SolarShares as a substitute for green pricing, even though RECs were used for RPS compliance rather than retired on behalf of subscribers. As the SolarShares program expanded, SMUD foresaw the possibility that some green pricing customers could switch from Greenergy to SolarShares. And, if this occurred, expanding the SolarShares program would result in reduced green power sales in SMUD's service territory, all else being equal.

In an effort to be transparent with participants and provide an authentic renewable program, SMUD amended its SolarShares program in 2017 so that the community solar RECs are retired on behalf of subscribers. As a result, the SolarShares program is now one of the largest green power community solar programs in the country. Furthermore, the expansion of SolarShares will only increase green power sales in SMUD's service territory, even if the program draws some customers out of the Greenergy green pricing program.

Information based on an interview with Wade Hughes, SMUD

\section{Above-RPS Utility Basic Service as a Green Power Product}

In the discussion above, we state that most utility basic service represents default power. However, as renewable energy costs decline, utilities are increasingly procuring renewable energy beyond levels required by state RPS. For instance, California's investor-owned utilities are on track to meet 2030 RPS targets by 2020 (Gattaciecca, Trumbull, and DeShazo 2018). Xcel Energy, which serves customers in eight different states, expects to source about $40 \%$ of its energy through wind by 2022, surpassing RPS requirements in multiple states well ahead of schedule (Xcel Energy 2018). MidAmerican Energy in Iowa currently delivers an electricity portfolio with about 50\% renewable energy (MidAmerican 2018) far exceeding the state's RPS. Above-RPS renewable energy content in utility electricity portfolios adds further complexity to electricity choice and the quantification of voluntary green power. 
The rise of above-RPS utility renewable energy procurement raises questions about the role of utility basic service in voluntary green power markets. Under our definition of green power as renewable electricity voluntarily purchased by retail electricity customers, we do not treat aboveRPS utility renewable energy sales as green power, under the rationale that retail electricity customers have not "voluntarily" procured renewable electricity. However, expanding electricity choice weakens this rationale and provides an argument for reconsidering how we define green power.

There may be some rationale for including utility basic service options with above-RPS renewable energy as green power, if the utility retires the RECs for its ratepayers. In restructured markets and in jurisdictions with CCAs, utility basic service is in fact a customer choicethough many customers may be unaware of the choice. If the utility provides more renewable energy than local competitive suppliers or the local CCA and a customer chooses to remain with the utility in order to buy more renewable energy, one could argue the customer has voluntarily procured renewable electricity through their decision to continue with utility basic service. As long as utilities retire above-RPS RECs on behalf of their ratepaying customers, there should be no potential for double claims to the renewable electricity. Indeed, from this perspective, it is unclear how green power claims based on above-RPS utility basic service differ from green power claims based on above-RPS competitive supplier or CCA service. From a research perspective, customers that procure green power by choosing to buy basic service are nearly impossible to identify, which raises difficult questions about how utility basic service green power could be quantified. The potential impacts of above-RPS utility renewable energy sales on green power markets are an area for further consideration and research. 


\section{Conclusions and Observations}

We estimate that about 5.5 million customers procured about 112 million MWh of voluntary green power in 2017 . And, the U.S. voluntary green power market continues to grow steadily: we estimate sales increased by about $27 \%$ from 2016 to 2017 . Green power sales increased for all seven green power products summarized in this report. Key trends by product include:

- Utility green pricing: Growth in sales continued to be driven by a few large programs, while sales remained stable in most programs. Utility green pricing programs are procuring more solar. Solar's share of green pricing sales increased from about $2 \%$ in 2013 to $14 \%$ in 2017 among the top 10 largest programs, and from less than 1\% in 2013 to $6 \%$ in 2017 among the remaining green pricing programs.

- Utility renewable contracts: Sales increased by $17 \%$ from 2016 to 2017. Fourteen utilities now offer utility green tariff programs, and bilateral contracts have been signed in six states. New utility green tariff contracts were signed in 2017 in New Mexico and Nevada.

- Competitive suppliers: Sales increased by 0.9 million MWh (12\%) from 2016 to 2017, primarily due to increases in sales by the largest competitive suppliers of green power.

- Unbundled RECs: Unbundled RECs continue to account for about half (46\%) of the voluntary green power market in terms of sales. The number of customers procuring unbundled RECs continued to increase, perhaps reflecting marketing efforts to residential and small commercial customers.

- CCAs: Sales increased by 2.3 million MWh (73\%) in California, Massachusetts, New York, and Ohio but declined by 1.5 million MWh (29\%) in Illinois from 2016 to 2017, resulting in a net year-over-year increase of about 0.8 million MWh (10\%). The ongoing expansion of green power CCAs in California, Massachusetts, and New York was likely to drive further growth in CCA green power sales in future years.

- PPAs: Green power sales through PPAs more than doubled from 2016 to 2017, accounting for nearly half of the total increase in U.S. voluntary green power sales. The significant increase was due primarily to PPA contracts that were signed in 2015 and came online for the first time in 2017.

- Community solar: Three large utility-administered programs and one CCA-administered community solar program now retire RECs on behalf of subscribers, and they generated about 4.7 million MWh of green power in 2017. However, the vast majority of community solar projects do not retire RECs on behalf of subscribers; these additional projects generated about 62.3 million MWh of solar output in 2017.

The ongoing growth of the U.S. voluntary green power market is driven primarily by (1) increased sales of existing products, especially unbundled renewable energy certificateswhich grew by 32 million MWh from 2010 to 2017-but also by (2) the expansion of new products such as CCAs and PPAs - which together grew by 29 million MWh from 2010 to 2017. As these new products expand, there is the potential for customer confusion and for customers to misunderstand the impact of their purchases. Measures to increase product transparency, particularly for new products such as CCAs and community solar, could help customers better understand the impact of their purchasing decisions. 


\section{References}

Barbose, G. 2017. U.S. Renewable Portfolio Standards 2017 Annual Status Report. Berkeley, CA: Lawrence Berkeley National Laboratory.

Binns, C. 2018. Community Choice Aggregation Informational Slide Deck. Joule Community Power.

Bonugli, C. et al. (forthcoming). Emerging Green Tariffs in U.S. Regulated Electricity Markets. World Resources Institute.

BNEF (Bloomberg New Energy Finance). 2018. US Corporate PPA Project Database.

CalCCA. 2018. "What is Community Choice Aggregation?” Accessed August 7, 2018: https://cal-cca.org/cca-impact/.

Chwastyk, D., J. Leader, J. Cramer, and M. Rolph. 2018. Community Solar Program Design Models. Smart Electric Power Alliance.

DSIRE (Database of State Incentives for Renewables and Efficiency). 2018. http://www.dsireusa.org. North Carolina Clean Energy Technology Center.

EIA (U.S. Energy Information Administration). 2016. 2016 Average Monthly Bill-Residential.

_. 2018a. Electric Power Sales, Revenue, and Energy Efficiency Form EIA-861.

—. 2018b. "Electricity Data Browser." Accessed September 6, 2018:

https://www.eia.gov/electricity/data/browser/.

EPA (U.S. Environmental Protection Agency). 2018. Guide to Purchasing Green Power. https://www.epa.gov/greenpower/guide-purchasing-green-power.

Gattaciecca, J., K. Trumbull, and J.R. DeShazo. 2018. The Growth in Community Choice Aggregation. UCLA Luskin Center for Innovation.

Gleckner, A. 2016. "MN Regulators Adopt First of its Kind Value of Solar Rate." Fresh Energy, July 21, 2016.

Hannah, L. 2017. “Xcel Energy's Community Solar Turns Three.” Fresh Energy, December 20, 2017.

Heeter, J., J. Cook, and L. Bird. 2017. Charting the Emergence of Corporate Procurement of Utility-Scale PV. Golden, CO: National Renewable Energy Laboratory. NREL/TP-6A20-69080. https://www.nrel.gov/docs/fy17osti/69080.pdf.

Homefield Energy. 2018. "Communities We Serve." Accessed August 8, 2018:

https://www.dynegy.com/homefield/municipal-aggregation/communities-we-serve.. 
Honeyman, C., MJ Shiao, and S. Krulewitz. 2017. U.S. Community Solar Outlook 2017. GTM Research.

ICC (Illinois Commerce Commission). 2018a. "Electric Switching Statistics." Accessed June 6, 2018: https://www.icc.illinois.gov/electricity/switchingstatistics.aspx.

—. 2018b. "List of Communities Pursuing Opt-Out Municipal Aggregation Program." Accessed on June 6, 2018: https://www.pluginillinois.org/MunicipalAggregationList.aspx.

Jones, T., R. Quarrier, and M. Kelty. 2015. The Legal Basis for Renewable Energy Certificates. San Francisco, CA: Center for Resource Solutions.

LEAN (Local Energy Aggregation Network). 2018. "CCA by State." http://www.leanenergyus.org/.

LBNL (Lawrence Berkeley National Laboratory). 2017. RPS Compliance Data. Received September 20, 2017. Public version available at https://emp.lbl.gov/projects/renewablesportfolio.

Leschke, M. 2018. Preliminary Totals of Green-e Certified Sales. Center for Resource Solutions. Data received August 31, 2018.

Lichtenstein, G., and I. Reid-Shaw. 2017. Community Choice Aggregation (CCA) in Massachusetts. University of New Hampshire Sustainability Institute.

MCE. 2018. Community solar data received September 27, 2018.

MN (Minnesota Commerce Department). 2018. “Tips About Community Solar.” Accessed August 10, 2018: https://mn.gov/commerce/consumers/your-home/energy-info/solar/tips-aboutcommunity-solar.jsp.

NextEra. 2018. "Renewable Energy Certificates." https://www.nexteraenergyresources.com/what-we-do/energy-marketing/recs.html.

NREL (National Renewable Energy Laboratory). 2015. Renewable Electricity: How do you know you are using it? NREL/FS-6A20-64558. https://www.nrel.gov/docs/fy15osti/64558.pdf.

—. 2018. Top Ten Utility Green Pricing Programs.

https://www.nrel.gov/analysis/assets/pdfs/utility-green-power-ranking.pdf, available via "Voluntary Green Power Procurement," https://www.nrel.gov/analysis/green-power.html.

NY PSC (Public Service Commission). 2018. PSC Approves Third Community Choice Aggregation Plan for Upstate New York, Providing New Options for Clean and Affordable Energy. January 18, 2018.

NYSERDA (New York State Energy Research and Development Authority). 2018. "NY-Sun Data \& Trends." 
O'Shaughnessy, J. Heeter, J. Cook, and C. Volpi. 2017. Status and Trends in the U.S. Voluntary Green Power Market (2016 Data). Golden, CO: National Renewable Energy Laboratory. NREL/TP-6A20-70174. https://www.nrel.gov/docs/fy18osti/70174.pdf.

O'Shaughnessy, E., M. Rolph, J. Sauer, J. Cramer. 2018. Community Solar Project Database. NREL/Coalition for Community Solar Access. https://data.nrel.gov/submissions/95.

PG\&E (Pacific Gas \& Electric). 2018. 2017 Annual Green Tariff Shared Renewables Program Report of Pacific Gas and Electric Company.

Revision Energy. 2018. Community Solar FAQs. https://www.revisionenergy.com/why-gosolar/solar-faqs/\#CommunitySolarFAQs.

Rogers, G. 2011. Consumer Attitudes About Renewable Energy: Trends and Regional Differences. Golden, CO: National Renewable Energy Laboratory. NREL/TP-6A20-50988. https://www.nrel.gov/docs/fy11osti/50988.pdf.

S\&P Global Market Intelligence. 2018. Power Plant Screening. Subscription-based service.

SNL Energy. 2018. REC Index. Data provided by Evolution Markets, Tradition Financial Services, Clear Energy Brokerage and Consulting, Karbone, and SREC Trade. Subscriptionbased service.

Tawney, L., P. Barua, and C. Bonugli. 2017. Emerging Green Tariffs in U.S. Regulated Electricity Markets. World Resources Institute.

Trabish, H. 2017. "A Tale of 2 States: Massachusetts and California Provide Different Lessons on Growing Community Solar.” Utility Dive, November 30, 2017.

Trumbull, K. 2018. Data set obtained August 13, 2018. UCLA Luskin Center for Innovation.

Westchester Power. 2018. Annual Report for Calendar Year 2017 for Westchester Power Community Choice Aggregation Program.

WRI (world Resources Institute). 2018. “Green Tariffs Map.” Accessed June 6, 2018: http://www.wri.org/green-tariffs-map.

Xcel Energy. 2017. "Solar*Rewards Community Subscriber Frequently Asked Questions." Accessed on August 10, 2018: https://www.xcelenergy.com/staticfiles/xeresponsive/Programs\%20and\%20Rebates/Residential/CO-Solar-Rewards-CommunitySubscriber-FAQ.pdf.

—. 2018. "Renewable Energy." Accessed September 6, 2018:

https://www.xcelenergy.com/company/corporate responsibility report/library of briefs/renewa ble energy. 


\section{Appendix. State-by-State Data Tables}

This appendix provides state-level estimates of green power participation (Table A-1) and generation (Table A-2).

These state-level estimates are approximations based on the best available data and should be treated as such.

Table A-1. Green Power Customers by State

\begin{tabular}{|c|c|c|c|c|c|c|c|c|}
\hline State & $\begin{array}{l}\text { Utility } \\
\text { Green } \\
\text { Pricing }\end{array}$ & $\begin{array}{l}\text { Utility } \\
\text { Contracts }\end{array}$ & $\begin{array}{l}\text { Competitive } \\
\text { Suppliers }\end{array}$ & $\begin{array}{l}\text { Unbundled } \\
\text { RECs }\end{array}$ & CCAs & PPAs & $\begin{array}{l}\text { Community } \\
\text { Solar }\end{array}$ & Total \\
\hline AK & 173 & 0 & 0 & 14 & 0 & 0 & 0 & 187 \\
\hline$A L$ & 7,808 & 0 & 0 & 239 & 0 & 0 & 0 & 8,047 \\
\hline$A R$ & 0 & 0 & 0 & 54 & 0 & 1 & 0 & 55 \\
\hline$A Z$ & 9,946 & 0 & 0 & 482 & 0 & 1 & 0 & 10,429 \\
\hline $\mathrm{CA}$ & 124,991 & 0 & 1,003 & 21,530 & $1,238,840$ & 131 & 2,029 & $1,388,524$ \\
\hline $\mathrm{CO}$ & 60,732 & 0 & 0 & 9,283 & 0 & 0 & 0 & 70,015 \\
\hline CT & 0 & 0 & 35,476 & 1,102 & 0 & 0 & 0 & 36,578 \\
\hline $\mathrm{DC}$ & 0 & 0 & 10,223 & 644 & 0 & 0 & 0 & 10,867 \\
\hline $\mathrm{DE}$ & 343 & 0 & 4,647 & 172 & 0 & 0 & 0 & 5,162 \\
\hline $\mathrm{FL}$ & 2,964 & 0 & 0 & 497 & 0 & 10 & 0 & 3,471 \\
\hline GA & 17,091 & 1 & 0 & 783 & 0 & 5 & 0 & 17,880 \\
\hline $\mathrm{HI}$ & 0 & 0 & 0 & 35 & 0 & 7 & 0 & 42 \\
\hline IA & 5,178 & 2 & 0 & 1,045 & 0 & 0 & 0 & 6,225 \\
\hline ID & 29,726 & 0 & 0 & 729 & 0 & 0 & 0 & 30,455 \\
\hline IL & 4,181 & 0 & 138,936 & 5,834 & 463,000 & 6 & 0 & 611,957 \\
\hline IN & 11,631 & 0 & 0 & 1,469 & 0 & 1 & 0 & 13,101 \\
\hline KS & 1,433 & 0 & 0 & 3,899 & 0 & 5 & 0 & 5,337 \\
\hline KY & 5,653 & 0 & 0 & 345 & 0 & 0 & 0 & 5,998 \\
\hline LA & 0 & 0 & 0 & 109 & 0 & 0 & 0 & 109 \\
\hline MA & 7,457 & 0 & 96,107 & 4,452 & 860,712 & 2 & 0 & 968,730 \\
\hline MD & 0 & 0 & 59,994 & 3,188 & 0 & 3 & 0 & 63,185 \\
\hline
\end{tabular}




\begin{tabular}{|c|c|c|c|c|c|c|c|c|}
\hline State & $\begin{array}{l}\text { Utility } \\
\text { Green } \\
\text { Pricing }\end{array}$ & $\begin{array}{l}\text { Utility } \\
\text { Contracts }\end{array}$ & $\begin{array}{l}\text { Competitive } \\
\text { Suppliers }\end{array}$ & $\begin{array}{l}\text { Unbundled } \\
\text { RECs }\end{array}$ & CCAs & PPAs & $\begin{array}{l}\text { Community } \\
\text { Solar }\end{array}$ & Total \\
\hline ME & 0 & 0 & 18,906 & 134 & 0 & 1 & 0 & 19,041 \\
\hline MI & 18,806 & 0 & 38 & 7,650 & 0 & 0 & 0 & 26,494 \\
\hline MN & 63,409 & 0 & 0 & 9,719 & 0 & 2 & 0 & 73,130 \\
\hline MO & 6,765 & 0 & 0 & 1,066 & 0 & 0 & 0 & 7,831 \\
\hline MS & 133 & 0 & 0 & 37 & 0 & 1 & 0 & 171 \\
\hline MT & 1,707 & 0 & 0 & 86 & 0 & 0 & 0 & 1,793 \\
\hline NC & 10,012 & 3 & 0 & 674 & 0 & 13 & 0 & 10,702 \\
\hline ND & 621 & 0 & 0 & 14 & 0 & 1 & 0 & 636 \\
\hline NE & 1,391 & 1 & 0 & 26 & 0 & 1 & 0 & 1,419 \\
\hline $\mathrm{NH}$ & 0 & 0 & 11,118 & 526 & 0 & 0 & 0 & 11,644 \\
\hline $\mathrm{NJ}$ & 0 & 0 & 70,602 & 879 & 0 & 2 & 0 & 71,483 \\
\hline NM & 3,588 & 0 & 0 & 266 & 0 & 0 & 0 & 3,854 \\
\hline NV & 3,412 & 4 & 0 & 75 & 0 & 0 & 0 & 3,491 \\
\hline NY & 24,462 & 0 & 229,274 & 15,246 & 64,002 & 4 & 0 & 332,988 \\
\hline $\mathrm{OH}$ & 2,966 & 0 & 84,460 & 5,713 & 99,698 & 2 & 0 & 192,839 \\
\hline OK & 3,342 & 1 & 0 & 56 & 0 & 9 & 0 & 3,408 \\
\hline OR & 214,499 & 0 & 3 & 47,310 & 0 & 1 & 0 & 261,813 \\
\hline PA & 0 & 0 & 198,131 & 2,853 & 0 & 1 & 0 & 200,985 \\
\hline RI & 4,803 & 0 & 13,435 & 153 & 0 & 0 & 0 & 18,391 \\
\hline SC & 7,192 & 0 & 0 & 766 & 0 & 1 & 0 & 7,959 \\
\hline SD & 439 & 0 & 0 & 13 & 0 & 0 & 0 & 452 \\
\hline $\mathrm{TN}$ & 10,287 & 1 & 0 & 1,704 & 0 & 4 & 0 & 11,996 \\
\hline TX & 21,432 & 0 & 718,148 & 5,301 & 0 & 47 & 0 & 744,928 \\
\hline UT & 25,591 & 0 & 0 & 9,404 & 0 & 4 & 2,680 & 37,679 \\
\hline VA & 28,912 & 2 & 67 & 6,060 & 0 & 4 & 0 & 35,045 \\
\hline
\end{tabular}




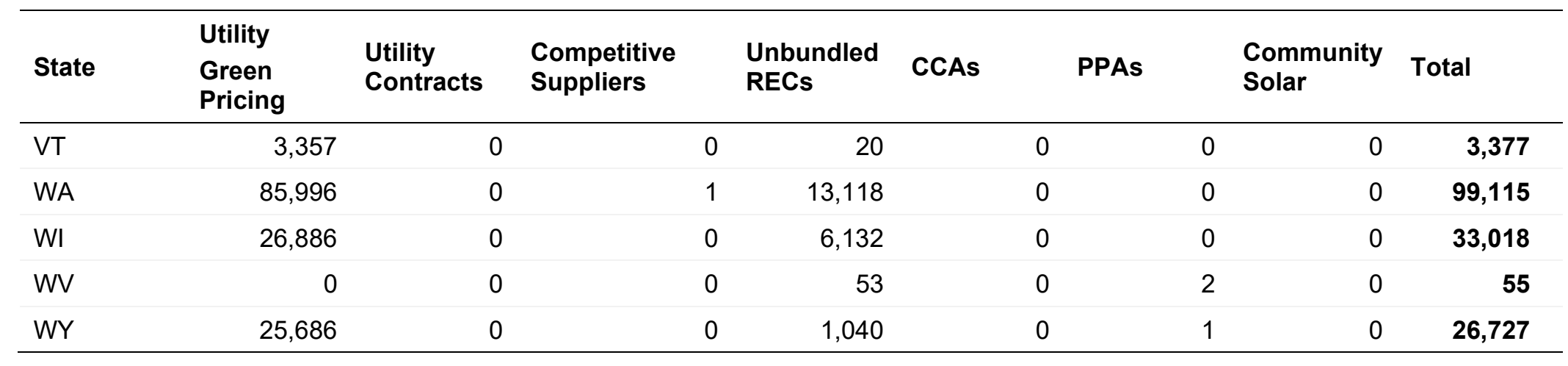


Table A-2. Estimated Green Power Production (MWh) by State of Origin ${ }^{a}$

\begin{tabular}{|c|c|c|c|c|c|c|c|c|}
\hline State & $\begin{array}{l}\text { Utility } \\
\text { Green } \\
\text { Pricing }\end{array}$ & $\begin{array}{l}\text { Utility } \\
\text { Contracts }\end{array}$ & $\begin{array}{l}\text { Competitive } \\
\text { Suppliers }\end{array}$ & $\begin{array}{l}\text { Unbundled } \\
\text { RECs }\end{array}$ & CCAs & PPAs & $\begin{array}{l}\text { Community } \\
\text { Solar }\end{array}$ & Total \\
\hline AK & 813 & 0 & 0 & 37,394 & 0 & 0 & 0 & 38,207 \\
\hline $\mathrm{AL}$ & 110,829 & 0 & 0 & 90,590 & 0 & 0 & 0 & 201,419 \\
\hline$A R$ & 0 & 0 & 0 & 182,553 & 0 & 27,200 & 0 & 209,753 \\
\hline$A Z$ & 209,734 & 0 & 0 & 72,886 & 32,654 & 54,141 & 0 & 369,415 \\
\hline CA & 596,194 & 0 & 12,776 & 485,232 & $1,566,794$ & $2,290,502$ & 36,996 & $4,988,494$ \\
\hline $\mathrm{CO}$ & 405,253 & 0 & 0 & 437,650 & 293,886 & 0 & 0 & $1,136,789$ \\
\hline $\mathrm{CT}$ & 0 & 0 & 43,557 & 0 & 490 & 0 & 0 & 44,047 \\
\hline DC & 0 & 0 & 449,311 & 0 & 0 & 0 & 0 & 449,311 \\
\hline $\mathrm{DE}$ & 54,153 & 0 & 92,171 & 0 & 0 & 0 & 0 & 146,324 \\
\hline $\mathrm{FL}$ & 13,908 & 0 & 0 & $1,051,183$ & 0 & 22,245 & 0 & $1,087,336$ \\
\hline GA & 209,665 & 111,033 & 0 & 698,733 & 0 & 53,714 & 0 & $1,073,145$ \\
\hline $\mathrm{HI}$ & 0 & 0 & 0 & 0 & 0 & 256,922 & 0 & 256,922 \\
\hline IA & 61,896 & $1,661,100$ & 52,304 & $1,970,807$ & 523,031 & 0 & 0 & $4,269,138$ \\
\hline ID & 905,518 & 0 & 0 & $1,216,976$ & 65,308 & 0 & 0 & $2,187,802$ \\
\hline IL & 130,466 & 0 & $1,692,230$ & 525,130 & $1,394,749$ & 893,609 & 0 & $4,636,184$ \\
\hline IN & 26,725 & 0 & 0 & 3,011 & 174,344 & 0 & 0 & 204,080 \\
\hline KS & 6,723 & 0 & 0 & $4,257,380$ & 0 & $1,581,381$ & 0 & $5,845,484$ \\
\hline KY & 104,641 & 0 & 0 & 19,527 & 0 & 0 & 0 & 124,168 \\
\hline LA & 0 & 0 & 0 & 63,200 & 0 & 0 & 0 & 63,200 \\
\hline MA & 26,636 & 0 & 144,700 & 118 & 153,704 & 10,044 & 0 & 335,202 \\
\hline MD & 0 & 0 & 336,826 & 0 & 592,768 & 10,929 & 0 & 940,523 \\
\hline ME & 0 & 0 & 1,282 & 0 & 72,454 & 69,248 & 0 & 142,984 \\
\hline MI & 125,762 & 0 & 48,763 & 126,558 & 0 & 0 & 0 & 301,083 \\
\hline MN & 341,141 & 0 & 0 & 616,297 & 139,475 & 18,291 & 0 & $1,115,204$ \\
\hline MO & 74,774 & 0 & 0 & 99,297 & 139,475 & 0 & 0 & 313,546 \\
\hline MS & 79,027 & 0 & 0 & 6,408 & 0 & 0 & 0 & 85,435 \\
\hline MT & 171,145 & 0 & 0 & 37,248 & 13,062 & 0 & 0 & 221,455 \\
\hline
\end{tabular}




\begin{tabular}{|c|c|c|c|c|c|c|c|c|}
\hline State & $\begin{array}{l}\text { Utility } \\
\text { Green } \\
\text { Pricing }\end{array}$ & $\begin{array}{l}\text { Utility } \\
\text { Contracts }\end{array}$ & $\begin{array}{l}\text { Competitive } \\
\text { Suppliers }\end{array}$ & $\begin{array}{l}\text { Unbundled } \\
\text { RECs }\end{array}$ & CCAs & PPAs & $\begin{array}{l}\text { Community } \\
\text { Solar }\end{array}$ & Total \\
\hline $\mathrm{NC}$ & 170,906 & 188,288 & 0 & 329,582 & 0 & 452,584 & 0 & $1,141,360$ \\
\hline ND & 37,011 & 0 & 0 & $1,928,584$ & 139,475 & 5,186 & 0 & $2,110,256$ \\
\hline NE & 40,624 & 118,260 & 0 & $2,124,820$ & 0 & 21,150 & 0 & $2,304,854$ \\
\hline $\mathrm{NH}$ & 0 & 0 & 3,741 & 1,963 & 34,936 & 0 & 0 & 40,640 \\
\hline NJ & 0 & 0 & 108,870 & 272 & 0 & 21,550 & 0 & 130,692 \\
\hline NM & 179,788 & 0 & 0 & $1,031,884$ & 0 & 0 & 0 & $1,211,672$ \\
\hline NV & 179,079 & 234,535 & 0 & 151,949 & 9,796 & 0 & 0 & 575,359 \\
\hline NY & 103,050 & 0 & 838,933 & 9,369 & 25,835 & 15,796 & 0 & 992,983 \\
\hline $\mathrm{OH}$ & 66,461 & 0 & 160,563 & 350 & 174,344 & 549,998 & 0 & 951,716 \\
\hline $\mathrm{OK}$ & 15,679 & 163,987 & 0 & $13,110,962$ & 0 & $3,955,166$ & 0 & $17,245,794$ \\
\hline OR & 865,813 & 0 & 0 & 601,577 & 65,308 & 131,242 & 0 & $1,663,940$ \\
\hline PA & 0 & 0 & 458,859 & 92,180 & 152,496 & 67,575 & 0 & 771,110 \\
\hline RI & 21,799 & 0 & 35 & 0 & 34,936 & 0 & 0 & 56,770 \\
\hline SC & 33,745 & 0 & 0 & 212,638 & 0 & 4,601 & 0 & 250,984 \\
\hline SD & 36,158 & 0 & 0 & $1,191,466$ & 34,869 & 0 & 0 & $1,262,493$ \\
\hline TN & 79,027 & 17,608 & 0 & 33,885 & 0 & 23,694 & 0 & 154,214 \\
\hline TX & 898,543 & 0 & $13,549,454$ & $15,902,710$ & $1,642,005$ & $10,441,515$ & 0 & $42,434,227$ \\
\hline UT & 525,712 & 0 & 0 & 845,101 & 6,531 & 10,820 & 43,418 & $1,431,582$ \\
\hline VA & 124,487 & 293,285 & 0 & 21,377 & 0 & 137,532 & 0 & 576,681 \\
\hline VT & 16,235 & 0 & 0 & 0 & 21,563 & 0 & 0 & 37,798 \\
\hline WA & $1,037,122$ & 0 & 0 & 513,918 & $1,044,929$ & 0 & 0 & $2,595,969$ \\
\hline WI & 237,227 & 0 & 106,208 & 128,079 & 69,737 & 0 & 0 & 541,251 \\
\hline WV & 0 & 0 & 32,556 & 7,387 & 34,869 & 137,182 & 0 & 211,994 \\
\hline WY & 526,531 & 0 & 0 & 530,839 & 32,654 & 6,789 & 0 & $1,096,813$ \\
\hline
\end{tabular}

a Sums across totals and states do not add to total green power sales because about 1.2 million MWh of green power is sourced from Canada 